UNIVERSIDADE DE SÃO PAULO

FACULDADE DE ECONOMIA, ADMINISTRAÇÃO E CONTABILIDADE DEPARTAMENTO DE CONTABILIDADE E ATUÁRIA PROGRAMA DE PÓS-GRADUAÇÃO EM CONTABILIDADE E CONTROLADORIA

\title{
UM MODELO DE TRIBUTAÇÃO DA RENDA POR FLUXOS DE CAIXA REALIZADOS
}

Silvio Hiroshi Nakao

Orientador: Prof. Dr. Alexandre Assaf Neto

São Paulo

2003 
Reitor da Universidade de São Paulo

Prof. Dr. Adolfo José Melfi

Diretor da Faculdade de Economia, Administração e Contabilidade

Profa. Dra. Maria Tereza Leme Fleury

Chefe do Departamento de Contabilidade e Atuária

Prof. Dr. Reinaldo Guerreiro

Coordenador do Curso de Pós-Graduação em Contabilidade e Controladoria Prof. Dr. Fábio Frezatti 
UNIVERSIDADE DE SÃO PAULO

FACULDADE DE ECONOMIA, ADMINISTRAÇÃO E CONTABILIDADE

DEPARTAMENTO DE CONTABILIDADE E ATUÁRIA

PROGRAMA DE PÓS-GRADUAÇÃO EM CONTABILIDADE E CONTROLADORIA

\section{UM MODELO DE TRIBUTAÇÃO DA RENDA POR FLUXOS DE CAIXA REALIZADOS}

Silvio Hiroshi Nakao

Orientador: Prof. Dr. Alexandre Assaf Neto

Tese apresentada ao Departamento de Contabilidade e Atuária como requisito para obtenção do título de Doutor em Controladoria Contabilidade 


\title{
FICHA CATALOGRÁFICA
}

\author{
Nakao, Sílvio Hiroshi \\ Um modelo de tributação da renda por fluxos de caixa \\ realizados/ Sílvio Hiroshi Nakao. \\ São Paulo : FEA/USP, 2003. \\ $195 \mathrm{p}$. \\ Tese - Doutorado \\ Bibliografia.
}

1. Contabilidade - Teoria 2. Contabilidade e legislação tributária 3. Contabilidade societária 4. Finanças Públicas 5. Contabilidade - normas I. Faculdade de Economia, Administração e Contabilidade da USP

$$
\text { CDD }-657
$$


À Sandra, por ter me mostrado que era possível. 


\section{AGRADECIMENTOS}

Ao Prof. Dr. Alexandre Assaf Neto, que por tanto tempo nos guia por esses belos campos da academia e a quem devo todo o desenvolvimento da minha carreira.

Ao Prof Dr. Eliseu Martins, pelas discussões acerca do tema da tese e pelas valiosas sugestões. Vi, com meus próprios olhos, o brilho de uma mente que sempre foi referência para todos nós.

À Profa. Dra. Maísa de Souza Ribeiro, profissional que respeito profundamente, mas sobretudo minha amiga. Agradeço por todas as sugestões e por tudo o que tem feito para me ajudar nessa caminhada.

Ao Prof. Dr. Natan Szuster, pela calorosa receptividade e pelas sugestões.

Ao Prof. Dr. Paulo Roberto Barbosa Lustosa, pela amizade, pelas fantásticas discussões e por toda ajuda que me deu nesses anos de Pós-Graduação.

Ao Prof. Aldo Vicenzo Bertolucci, pela colaboração, pelas sugestões e pela disposição em ajudar.

Ao meu amigo Carlos Roberto de Godoy, por me acompanhar bravamente nessa difícil etapa que é a elaboração da tese. Chegamos vivos!

Ao meu irmão Marcos Kenji Nakao, pelo auxílio nas questões jurídicas, tão incompreensíveis para mim.

Ao amigo Marcelo Botelho da Costa Moraes, pelas elevadas discussões.

A Júlio César Curvo e Jefferson Rodrigues, da Secretaria da Receita Federal, que me ajudaram imensamente. 
Aos meus professores do Programa de Doutorado: Prof. Dr. Sergio de Iudícibus, Prof. Dr. Luiz João Corrar, Prof. Dr. Gilberto de Andrade Martins, Prof. Dr. Armando Catelli, Prof. Dr. Lázaro Plácido Lisboa, Prof. Dr. Paulo Furquim de Azevedo, Prof. Dr. Edgard Monforte Merlo e Prof. Dr. Alberto Borges Matias.

Aos colegas Álvaro Ricardino, Carlos Renato Theóphilo, Cláudio Jorge Monteiro, Edilene Santana Santos, Márcia Carvalho dos Santos e Vicente Rosseto, pelas valiosas discussões.

À 'Turma': Roni Cleber Bonizio, E. Fernando R. Vicente, Paulo Roberto de Paiva, Marcos Antonio Sanches, Eduardo de Brito, Vinícius Aversari Martins e todos os que se juntaram a essa família.

Aos funcionários da FEA/USP, especialmente os da secretaria do PósGraduação, atenciosos e prestativos.

Ao Departamento de Contabilidade da FEA-RP/USP, em especial ao Prof. Dr. José Carlos Marion e à Profa. Dra. Adriana Procópio de Araújo, pelas condições proporcionadas para que este trabalho chegasse ao seu final.

Aos colegas dos departamentos de Contabilidade, de Economia e de Administração da FEA-RP/USP, que me acolheram tão amigavelmente.

Aos meus alunos da FEA-RP/USP, que me mantêm motivado graças à enorme vontade em aprender.

À Capes, pelo apoio financeiro durante um período importante do curso.

Aos meus pais, por tudo o que me ensinaram e me ajudaram, meu eterno agradecimento.

A Deus, por ter me mostrado, mais uma vez, tão clara presença. 


\section{RESUMO}

Este trabalho procura desenvolver um modelo de tributação da renda gerada pelas empresas com base em fluxos de caixa realizados, ao invés da base lucro em regime competência, mas na óptica dos conceitos contábeis. Além disso, procura analisar as implicações do modelo sobre os custos de conformidade, sobre a capacidade de pagamento, a interferência das normas tributárias sobre os princípios contábeis e a arrecadação. No desenvolvimento do modelo, procurou-se verificar quais são os fluxos de caixa tributáveis, os não-tributáveis, o tratamento a ser dado às movimentações virtuais de caixa e à inflação. Para isso, foram levantados e analisados as teorias e conceitos que suportam esse desenvolvimento. Com o modelo elaborado, foram analisadas suas implicações. Verificou-se que o modelo pode reduzir custos de conformidade tanto do lado do contribuinte, como do fisco, principalmente em função da maior facilidade de apuração; que o contribuinte pode aumentar sua capacidade contributiva, tanto do ponto de vista financeiro como econômico; que permite uma redução da interferência das normas tributárias sobre a elaboração das demonstrações contábeis; e, por último, que a arrecadação pode até ser equivalente à obtida com a tributação baseada no lucro, apesar de ser menos regular. 


\section{ABSTRACT}

This thesis aims to develop a business income taxation based on realized cash flows model, instead of profit basis, but by the point of view of accounting concepts. Moreover, it attempts to analyze the implications of model upon compliance costs, contribution ability, interference of tax rules on accounting principles and upon collecting tax. On model development, was make an effort to verify which are the taxable cash flows, the non-taxable, virtual cash flows and inflation treatment. Toward, we review and analyze theories and concepts that support this development. Following the arranged model, was analyzed its implications. We verified that the model can reduces compliance costs, such taxpayer side as public revenue side, mainly because of major evaluation simplicity; that the taxpayer can have his contribution ability increased, financially and economically; that permits a reduction of interference of tax rules on accounting principles; and for last, that collecting tax can be up to equivalent as achieved with profit tax basis, even less regular. 


\section{SUMÁRIO DAS TABELAS}

Tabela 2.1 - Estatística de Prazos Médios.................................................. 6

Tabela 2.2 - Princípios contábeis versus critérios fiscais ............................... 10

Tabela 2.3 - Custos de conformidade das companhias abertas ...................... 13

Tabela 3.1 - Patrimônio Líquido Inicial .................................................... 41

Tabela 3.2 - DMPL com Lucro Líquido...................................................... 41

Tabela 3.3 - Patrimônio Líquido Final...................................................... 41

Tabela 3.4 - Variação do PL com Lucro Medido pelo Valor Adicionado ................ 43

Tabela 3.5- Dados Integrantes das Decisões sobre Estrutura de Capital ............ 74

Tabela 4.1 - Balanço Patrimonial com Imobilizado ..................................... 107

Tabela 4.2 - DRE com resultado na venda de imobilizado............................. 107

Tabela 4.3 - DFC com aquisição e venda de imobilizado................................ 107

Tabela 4.4 - Depreciação com ativos a valor de mercado ............................... 108

Tabela 4.5 - DRE com depreciação de ativos a valor de mercado .................... 108

Tabela 4.6 - Balanço e DRE de Controlada 100\% ...................................... 110

Tabela 4.7 - Balanço da controladora ...................................................... 110

Tabela 4.8 - DRE da controladora .................................................... 110

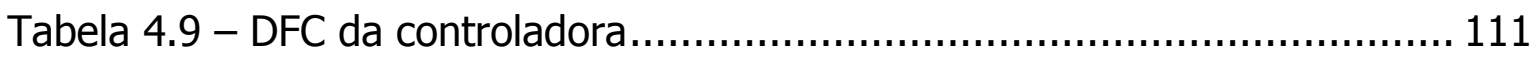

Tabela 4.10 - Balanço e DRE sem inflação ................................................ 115

Tabela 4.11 - Índices de inflação aplicados .............................................. 116

Tabela 4.12 - Ganhos e perdas do período 1 em moeda de final de 1 ...............116

Tabela 4.13 - DRE do Período 1 em CMI ..................................................... 116

Tabela 4.14 - Ganhos e Perdas do Período 2 em Moeda de Final de 2 ............. 116 
Tabela 4.15 - DRE do Período 2 em CMI

Tabela 4.16 - Ganhos e Perdas do Período 3 em Moeda de Final de 3

Tabela 4.17 - DRE do Período 3 em CMI

Tabela 4.18 - DRE em Moeda de Final do Período 3

Tabela 4.19 - DFC dos Três Períodos em Moeda de Final do Período 3 118

Tabela 4.20 - DRE dos Três Períodos em Moeda de Final do Período 3 120

Tabela 4.21 - DFC dos Quatro Períodos e Com Perdas no Caixa..................... 120

Tabela 4.22 - Movimentação de Estoques nos Quatro Períodos..................... 127

Tabela 4.23 - Impostos Calculados com Base no Lucro dos Quatro Periodos .... 128

Tabela 4.24 - Balanço dos Quatro Períodos ....................................... 128

Tabela 4.25 - DFC dos Quatro Períodos .......................................... 129

Tabela 4.26 - Apuração dos Tributos com Base nos Fluxos de Caixa Tributáveis 130

Tabela 4.27 - Índices de Inflação Considerados. 131

Tabela 4.28 - Movimentação de Caixa Sem Inflação com Impostos Apurados com Correção 132

Tabela 4.29 - Apuração das Perdas Inflacionárias no Caixa 132

Tabela 4.30 - Apuração dos Ganhos e Perdas Inflacionários nos Empréstimos.. 133

Tabela 4.31 - Apuração de IR/CS por Fluxo de Caixa Com Inflação ................ 134

Tabela 4.32 - DRE dos Cinco Períodos em CMI ...................................... 135

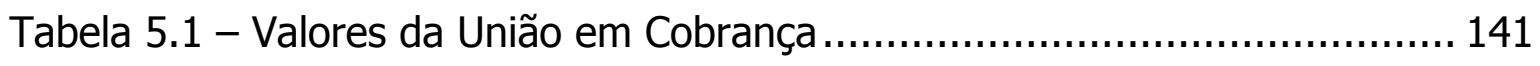

Tabela 5.2 - Formas Preferidas de Financiamento em Geral...................... 144

Tabela 5.3 - Demonstração do Fluxo de Caixa - Embraer S/A ....................... 146 
Tabela 5.4 - Capacidade Econômica e Financeira........................................... 149

Tabela 5.5- Quanto Custa Pagar Imposto? ............................................. 165

Tabela 5.6 - As Fases do Processo de Pagar Tributo .................................... 166

Tabela 5.7 - As Fases do Processo de Arrecadação do Tributo ......................... 170

Tabela 5.8 - Geração de Caixa e Lucro Líquido Período 1998-2002 .................. 178

Tabela 5.9 - Geração de Caixa e Lucro Líquido de 1998 ................................. 179

Tabela 5.10 - Geração de Caixa e Lucro Líquido de 1999 ................................ 180

Tabela 5.11 - Geração de Caixa e Lucro Líquido de 2000 .............................. 180

Tabela 5.12 - Geração de Caixa e Lucro Líquido de 2001 .............................. 181

Tabela 5.13 - Geração de Caixa e Lucro Líquido de 2002 ............................. 181

Tabela 5.14 - Geração de Caixa e Lucro Líquido Período 1998-2001 ................ 182

Tabela 5.15 - Resumo dos Testes Estatísticos .......................................... 182 


\section{SUMÁRIO DAS FIGURAS}

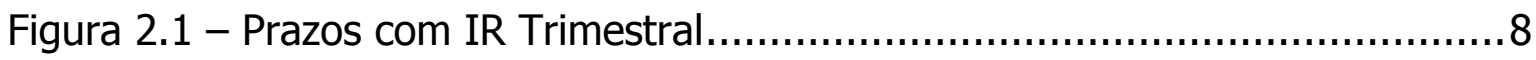

Figura 2.2 - Prazos com IR Anual e Pagamento por Estimativa .......................... 8

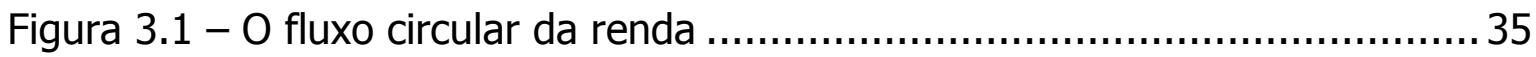

Figura 3.2 - Ativos a valores de entrada e de saída.........................................53

Figura 5.1 - Prazos com IR Anual e Pagamento por Estimativa ....................... 140

Figura 5.2 - Demanda por Automóveis de Alta e Baixa Qualidade ................... 158

Figura 5.3- Comportamento Geração de Caixa e Lucro Líquido ....................... 183 


\section{SUMÁRIO}

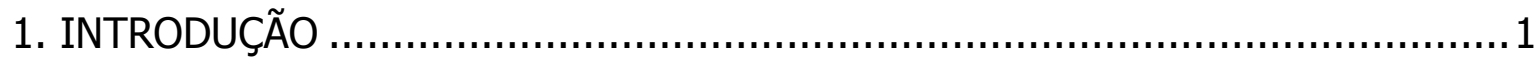

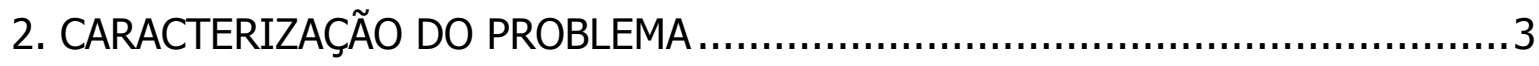

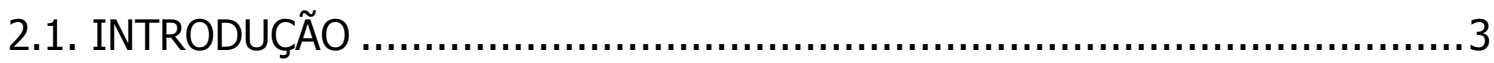

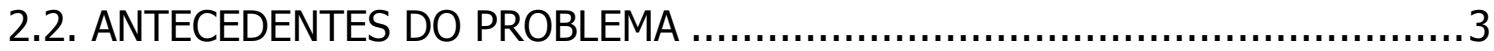

2.2.1. Capacidade de Pagamento ........................................................

2.2.2. Princípios Contábeis Versus Critérios Fiscais para Contabilização.......... 9

2.2.3. Custos de Conformidade .......................................................... 12

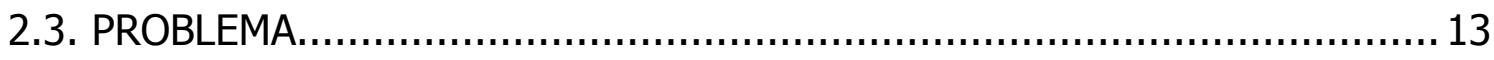

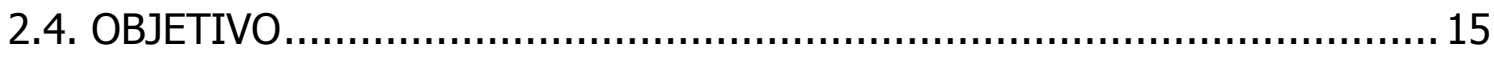

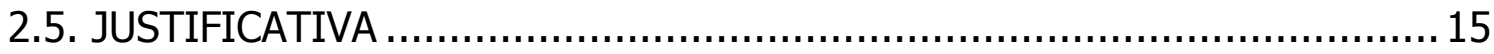

2.5.1. Tendência de Simplificação da Sistemática de Arrecadação .................16

2.5.2. Tendência de Aproximação do Conceito de Caixa ............................... 17

2.5.3. O Modelo de Tributação da Pessoa Física ........................................ 17

2.6. ORGANIZAÇÃO E DELIMITAÇÃO DO TRABALHO …............................... 18

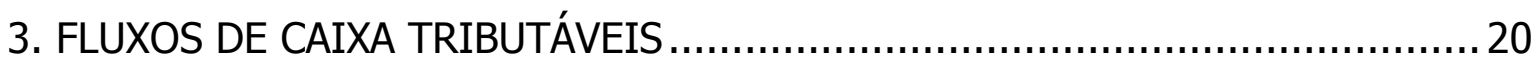

3.1. INTRODUÇÃO

3.2. TRIBUTAÇÃO SOBRE A RENDA ........................................................ 20

3.2.1. O Apelo da Tributação sobre a Renda ........................................ 20

3.2.2. Histórico e Origens ..................................................................... 22

3.2.3. Críticas à Tributação sobre a Renda ............................................. 23

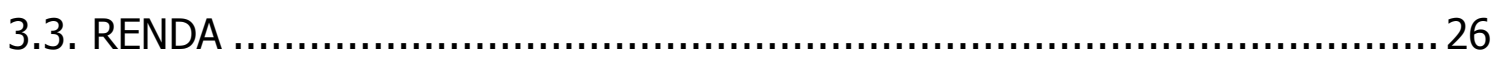

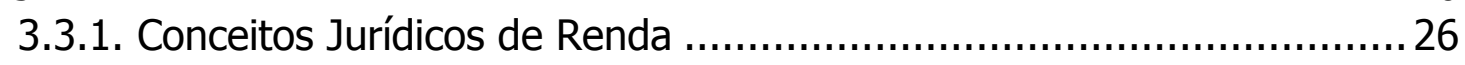

3.3.2. Conceitos Econômicos de Renda .................................................. 29

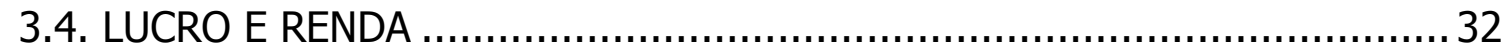

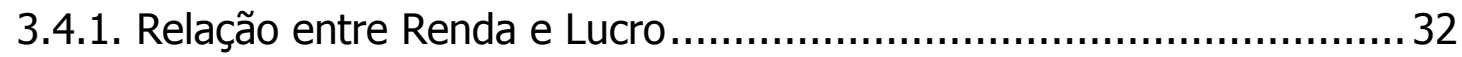

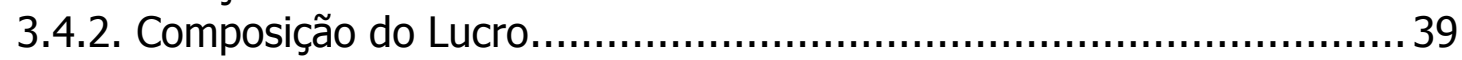

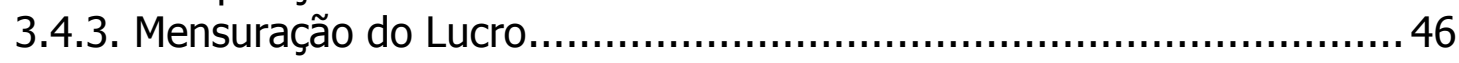

3.4.4. Avaliação de Ativos e Passivos.......................................................... 49

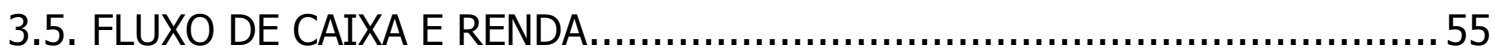

3.6. RENDA E LUCRO TRIBUTÁVEL...................................................... 58

3.6.1. O que é Atualmente o Lucro Tributável .........................................58

3.6.2. O que Deveria Ser Renda Tributável? ...........................................60

3.6.3. O que Deveria Ser Lucro Tributável? ............................................ 62

3.6.4. A Teoria de Modigliani e Miller sobre Estrutura de Capital ..................6 64 
3.6.5. Considerações a Respeito do Lucro Tributável................................. 75

3.7. TRIBUTAÇÃO SOBRE O FLUXO DE CAIXA ..........................................77

3.7.1. Composição dos Fluxos de Caixa.................................................. 77

3.7.2. Relações entre Renda Tributável e Fluxos de Caixa Tributáveis ..........81

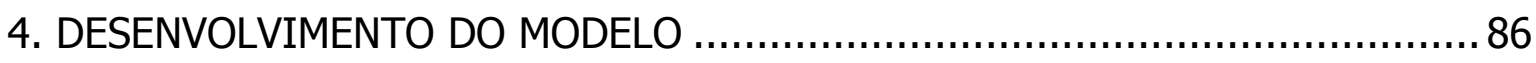

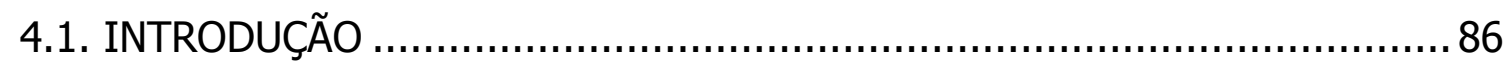

4.2. A TRIBUTAÇÃO ATUAL SOBRE A RENDA NO BRASIL ............................87

4.2.1. Competência, Função e Fato Gerador........................................... 87

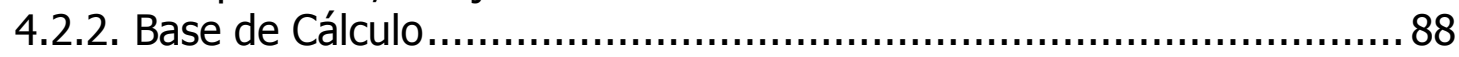

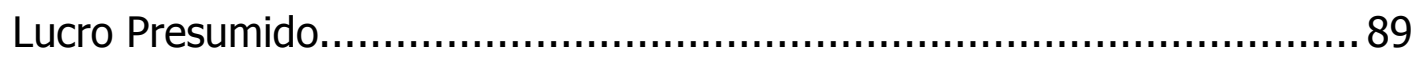

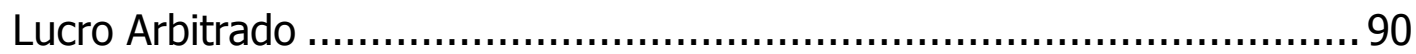

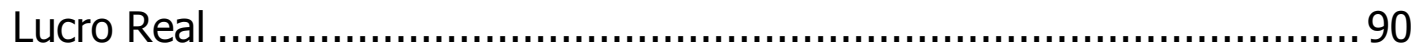

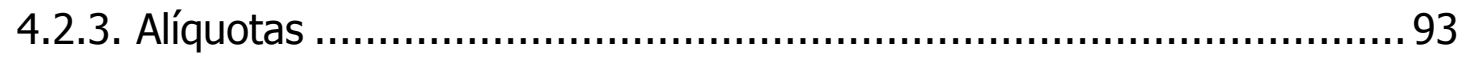

4.2.4. Valor do Imposto a Pagar............................................................ 94

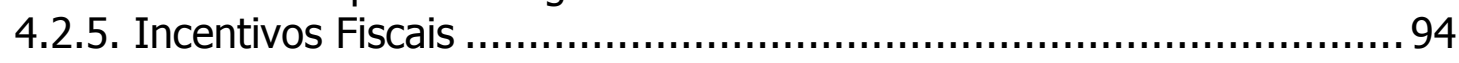

4.3. ANÁLISE DO MODELO DE TRIBUTAÇÃO ATUAL ..................................96

4.3.1. Lucro Presumido e Arbitrado ...................................................... 96

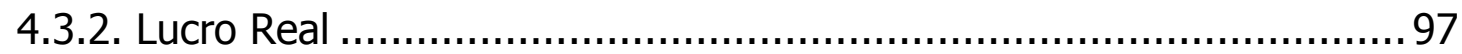

4.4. A TRANSPOSIÇÃO PARA O MODELO DE TRIBUTAÇÃO DA RENDA COM BASE NO FLUXO DE CAIXA .......................................................... 100

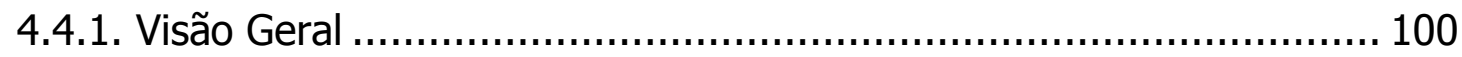

4.4.2. Competência, Função e Fato Gerador......................................... 101

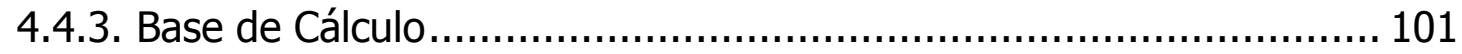

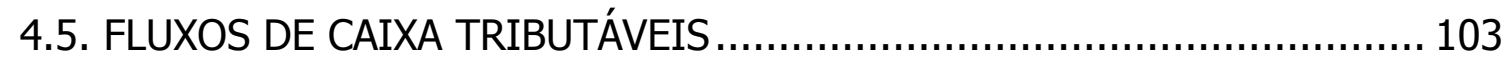

4.5.1. Fluxos de Caixa Operacionais .................................................. 103

4.5.2. Fluxos de Caixa de Investimentos ........................................... 105

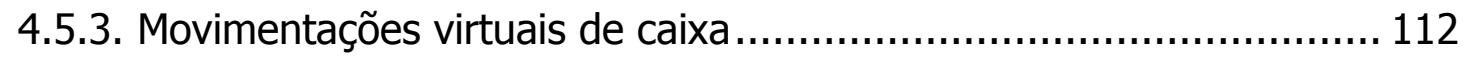

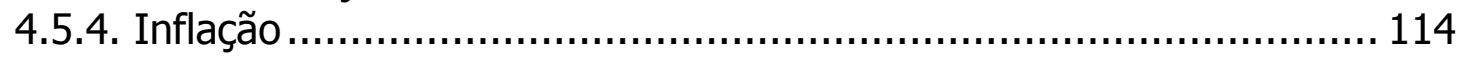

4.6. FLUXOS DE CAIXA NÃO-TRIBUTÁVEIS .......................................... 122

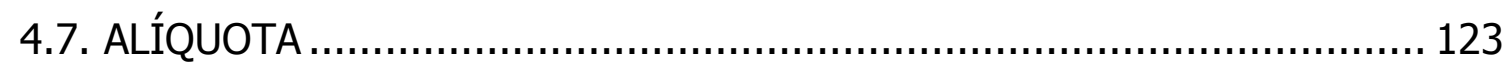

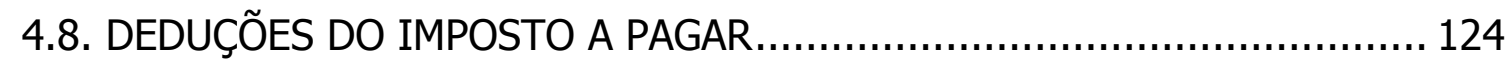

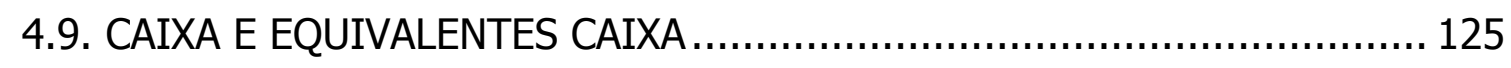

4.10. EXEMPLO DE TRIBUTAÇÃO POR FLUXOS DE CAIXA..........................126

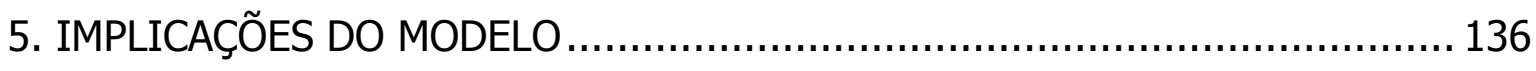

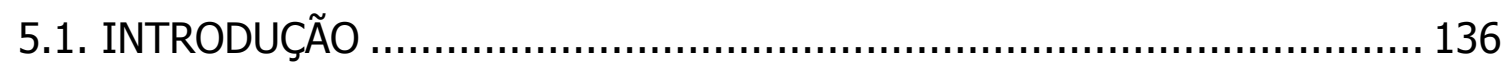

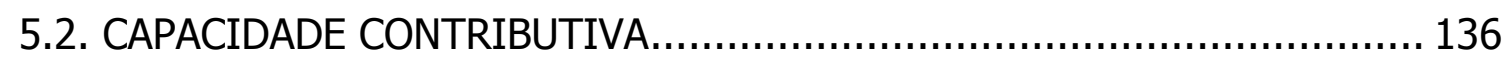

5.2.1. Conceito de Capacidade Contributiva ......................................... 136

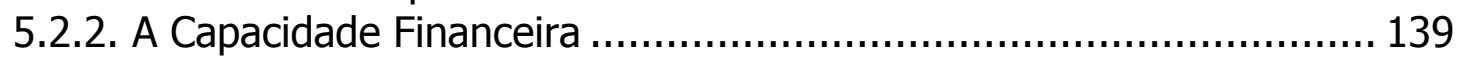


5.2.3. Implicações do Modelo sobre a Capacidade Contributiva................. 148

5.3. PRINCÍPIOS CONTÁBEIS............................................................. 150

5.3.1. A Interferência das Normas Tributárias sobre os PCGA .................... 150

5.3.2. A Interferência das Normas Tributárias com o Modelo de por Fluxos de

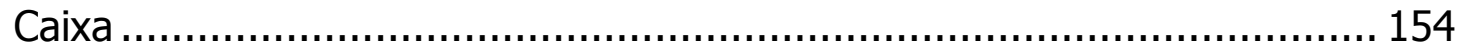

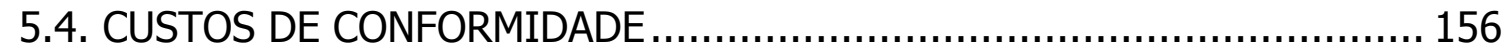

5.4.1. Os Custos de Conformidade ................................................... 156

5.4.2. Uma Explicação Para os Custos de Conformidade: a Assimetria de

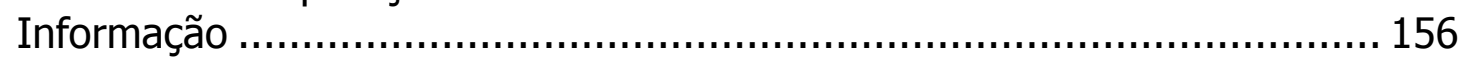

5.4.3. A Assimetria de Informação no Imposto de Renda ......................... 161

5.4.4. Os Mecanismos de Obtenção da Informação e Seus Custos .............. 163

5.4.5. Os Custos de Conformidade do Contribuinte no Modelo de Tributação por Fluxos de Caixa....................................................................... 166

5.4.6. Custos de Conformidade do Governo ........................................... 169

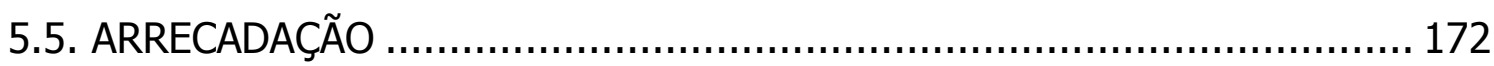

5.5.1. A Arrecadação com o Modelo de Tributação sobre Fluxos de Caixa.. 172

5.5.2. Estudo sobre Diferenças de Arrecadação ......................................173

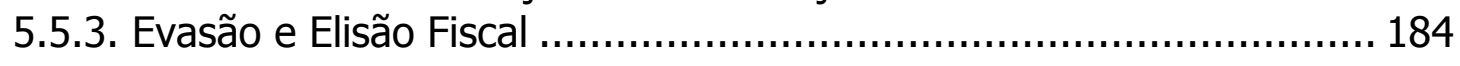

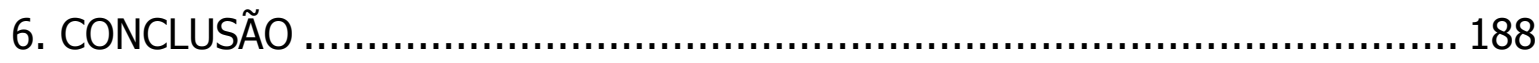

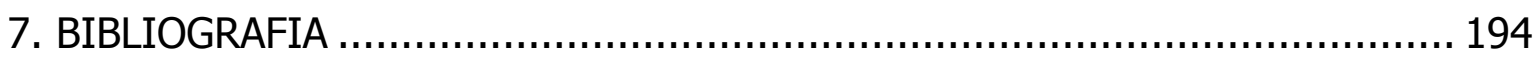




\section{INTRODUÇÃO}

Não é de hoje que a prática contábil no Brasil é severamente influenciada pela legislação tributária, que muitas vezes impõe regras que acabam por ditar os procedimentos contábeis a serem adotados, interferindo no cumprimento dos princípios contábeis geralmente aceitos.

Uma parte considerável desses problemas decorre da base de cálculo dos tributos diretos: o lucro contábil ajustado. Na legislação brasileira, esse lucro contábil deve ser ajustado para se apurar o chamado Lucro Real, que é a base para a aplicação das alíquotas de Imposto de Renda e Contribuição Social sobre o Lucro.

Vamos centrar nossa discussão sobre a tributação da renda gerada pelas empresas.

Além das alíquotas incidentes, a empresa também tem que enfrentar outros problemas relacionados à tributação da renda: os de capacidade de pagamento e de custos de conformidade.

Em relação à capacidade de pagamento, muitas vezes a empresa sofre dificuldades em sua administração do capital de giro por causa dos vencimentos dos tributos, que às vezes ocorrem antes do recebimento das vendas, o que a obriga a pagar com outras fontes de recursos.

Os custos de conformidade ocorrem em função da necessidade de se apurar o imposto de renda. A empresa tem que incorrer em uma série de custos 
além do próprio imposto. São custos que vão do treinamento sobre as normas tributárias à auditoria interna. O governo também incorre em custos de conformidade, desde a elaboração das normas tributárias, até processos judiciais.

Esses problemas são analisados neste trabalho do ponto de vista de uma proposta: tributar a renda não com base no lucro, mas a partir dos fluxos de caixa realizados.

A princípio, tributar dessa forma parece amenizar o problema da interferência das normas tributárias sobre a contabilidade, porque o foco passa a não ser mais o lucro, que é o principal objeto de mensuração da contabilidade.

Entretanto, é preciso analisar a proposta com maior profundidade e abrangência, levando em conta também os outros problemas apontados. É necessário avaliar até que ponto ela efetivamente traz vantagens como substituto ao modelo de apuração do imposto com base no lucro.

Assim, o trabalho está estruturado da seguinte forma: primeiramente, é caracterizado o problema, para então se moldar a base conceitual e teórica. A partir disso, é desenvolvido o modelo em seus detalhes técnicos, para então se discutir suas implicações em termos de capacidade de pagamento do contribuinte, de interferência das normas tributárias sobre os princípios contábeis, sobre os custos de conformidade e sobre a arrecadação do governo. 


\section{CARACTERIZAÇÃO DO PROBLEMA}

\subsection{INTRODUÇÃO}

Neste capítulo, se faz a caracterização do problema, começando por seus antecedentes, que são a questão da capacidade de pagamento do contribuinte, a interferência da legislação tributária sobre os princípios contábeis e os custos de conformidade.

A partir disso, são então colocados o problema, o objetivo do trabalho e porque ele se justifica.

\subsection{ANTECEDENTES DO PROBLEMA}

\subsubsection{Capacidade de Pagamento}

Como o imposto de renda é calculado sobre o lucro, apurado em regime de competência, pode haver a ocorrência de um problema operacional: as empresas têm que pagar o imposto às vezes sem ter recebido toda a receita obtida a prazo, prejudicando o capital de giro.

Para comprovar essa afirmação, foi realizada uma análise estatística a partir da base de dados secundários do software da Economática Ltda, com conteúdo baseado nas demonstrações contábeis publicadas, com os seguintes parâmetros: 
- Foram selecionadas empresas brasileiras com ações na Bovespa (Bolsa de Valores de São Paulo), sendo que foi considerada apenas uma ação por empresa;

- Foram filtradas as empresas com ciclo operacional não nulo, calculado a partir do último balanço de 12 meses dos valores consolidados, com base em abril de 2003.

Com esses parâmetros, foram obtidos dados de 271 empresas, dos quais foram extraídos os seguintes índices, calculados pelo próprio software:

- Prazo Médio de Recebimento de Vendas (PMRV) - número médio de dias entre a realização das vendas e o seu recebimento, calculado pela seguinte fórmula:

$$
\text { PMRV }=\frac{\text { Contas a Receber Médio }}{\text { Vendas Anuais a Prazo }} \cdot 360
$$

- Prazo Médio de Estocagem (PME) - número médio de dias necessários para que os estoques sejam renovados completamente, com o seguinte cálculo:

$$
\text { PME }=\frac{\text { Estoque Médio }}{\text { Custo dos Produtos Vendidos }} .360
$$

- Prazo Médio de Pagamento de Fornecedores (PMPF) - número médio de dias entre a compra realizada com os fornecedores da empresa e o seu pagamento, calculado da seguinte forma:

$$
\mathrm{PMPF}=\frac{\text { Fornecedores Médio }}{\text { Compras Anuais a Prazo }} \cdot 360
$$

- Ciclo Operacional (CO) - representa o tempo transcorrido entre a compra dos estoques até o recebimento da venda desses produtos, que 
é o somatório do Prazo Médio de Estocagem e o Prazo Médio de Recebimento de Vendas;

- Ciclo de Caixa (CC) - representa o número de dias do ciclo operacional que não é coberto pelo financiamento dos fornecedores, tendo que ser financiado por recursos em caixa, provindos de capital próprio ou de terceiros.

Apesar de esses índices terem sido obtidos diretamente da própria base de dados, há ressalvas a serem feitas. No caso de PMRV, a ressalva fica por conta das vendas anuais, uma vez que podem ou não conter o valor do IPI (Imposto sobre Produtos Industrializados). No caso de PMPF, as compras não contêm IPI e ICMS (Imposto sobre Circulação de Mercadorias e Serviços), embora o valor de Fornecedores contenha, pois provavelmente foram calculadas com base no Custo das Mercadorias Vendidas. Por não ser possível realizar os ajustes necessários, consideramos os dados como foram apresentados.

Foi estabelecido um limite de 1.440 dias (quatro anos), tanto para mais, como para menos, para reduzir a variabilidade dos dados. Ciclos Operacionais e de Caixa acima de quatro anos indicam atividades ou situações muito diferenciadas, que não entram no escopo do trabalho.

Apurados os números, verificou-se a existência de apenas quatro outliers ${ }^{1}$, que foram devidamente retirados da amostra em observação. As empresas Copas e JB Duarte tinham CC de $-67.255,8$ dias e $-28.246,2$ dias,

\footnotetext{
${ }^{1}$ Valores mais do que extremos, completamente diferentes da maioria dos valores da amostra.
} 
respectivamente, muito aquém da média. Do outro lado, foram também retiradas as empresas Itausa e Mendes Jr., que apresentaram CC de 2.139,3 dias e $4.514,8$ dias, respectivamente.

Com esses dados ajustados, foram obtidos a média, o desvio-padrão e a mediana de cada índice das 267 empresas selecionadas, conforme tabela a seguir:

Tabela 2.1 - Estatística de Prazos Médios

\begin{tabular}{lrrrrr} 
& PMRV & PME & PMPF & CO & \multicolumn{1}{c}{ CC } \\
\hline Média & 75,5 & 73,7 & 60,1 & 149,2 & 89,1 \\
Desvio-Padrão & 90,4 & 85,3 & 51,5 & 132,4 & 140,4 \\
Mediana & 62,6 & 62,6 & 48,9 & 128,9 & 76,4 \\
\hline
\end{tabular}

A partir disso, é possível observar que a distância entre a venda e o seu recebimento é, em média, de 75,5 dias, com alto desvio padrão, de 90,4 (justificável em função da diversidade de empresas contidas na amostra).

Para mostrar que as empresas têm que pagar o imposto às vezes sem ter recebido toda a receita obtida a prazo, é preciso comparar esse número com o prazo de pagamento dos tributos.

Pela sistemática de tributação do imposto de renda vigente em 2002 e 2003, os anos da análise estatística realizada acima, há a opção de fazer sua apuração trimestralmente ou anualmente, se considerarmos a tributação pela sistemática do lucro real (posteriormente ela será analisada com mais pormenores). Na opção pela apuração trimestral, o lucro apurado durante esse período é tributado na sua apuração, com vencimento no último dia do mês subseqüente. Já pela apuração anual, há uma espécie de adiantamento mensal ao governo, baseado em um lucro estimado sobre as vendas, com eventuais diferenças pagas até o último dia de março do ano subseqüente. 
Entretanto, isso não significa que a empresa, grosso modo, tem apenas 30 dias para pagar seus tributos. 0 imposto de renda a pagar, assim como qualquer outro tributo a pagar, tem uma característica peculiar, enquanto Passivo Cíclico (passivo que se renova de forma cíclica, conforme as operações da empresa, como Fornecedores).

Como todo tributo tem uma data de vencimento, há o que podemos chamar de um passivo "sanfona". À medida que os dias vão se passando e as operações vão se realizando, há o acúmulo dos tributos a pagar no Passivo, até a data do vencimento. Em geral, o vencimento ocorre em uma data após o período de ocorrência do fato gerador dos tributos, o que faz com que o valor acumulado entre o último dia desse período até a data do vencimento seja 0 valor mínimo desse passivo. O valor máximo é o acumulado desde o primeiro dia do período até a data do vencimento. Daí vem o efeito "sanfona".

Aplicando esse raciocínio à apuração trimestral do IR, o lucro obtido no primeiro dia do trimestre soma-se, juntamente com os demais, ao lucro do último dia do mesmo trimestre. Assim, o IR sobre o lucro do primeiro dia só será pago 120 dias depois, mas o lucro do último dia será pago 30 dias após.

Se pegarmos uma empresa que esteja, por exemplo, na média, com prazo de recebimento de 76 dias, no vencimento dos tributos ela não teria recebido ainda a metade das vendas do período, porque no dia 120 ela teria acumulado apenas o recebimento das vendas do dia $1^{\circ}$ ao dia 44 . As vendas desse dia ao dia 90 seriam recebidas após o vencimento dos tributos, como se pode ver na figura abaixo: 
Figura 2.1 - Prazos com IR Trimestral

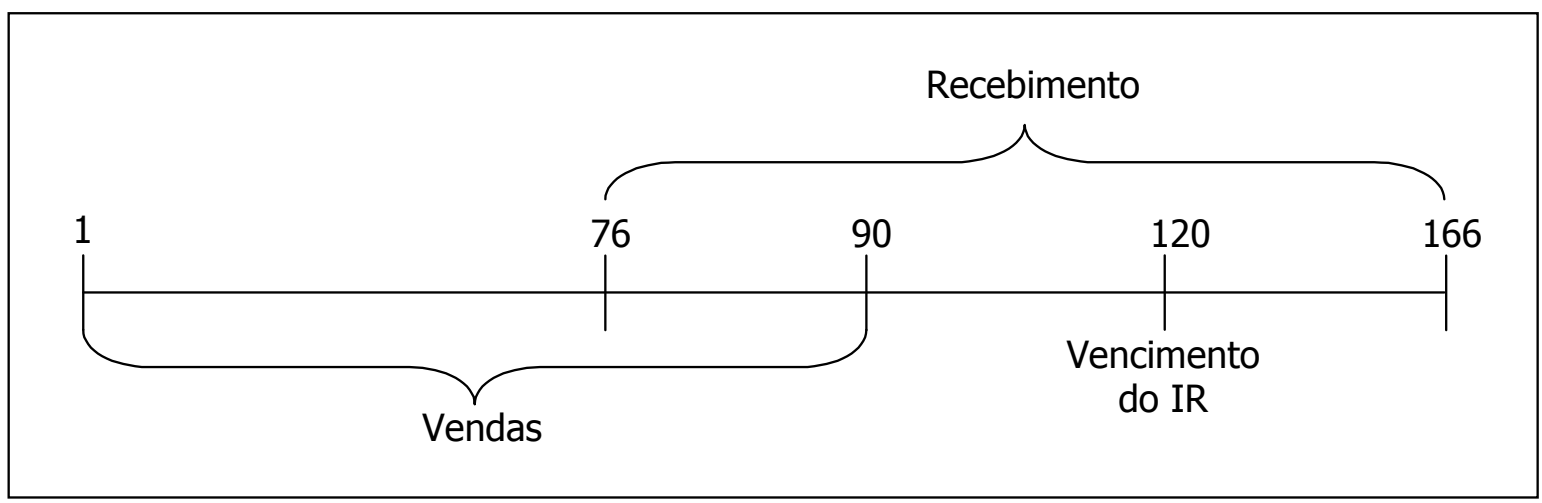

Pela apuração anual do IR com adiantamentos mensais baseados em estimativas de lucro, a situação pode ser ainda mais crítica.

Figura 2.2 - Prazos com IR Anual e Pagamento por Estimativa

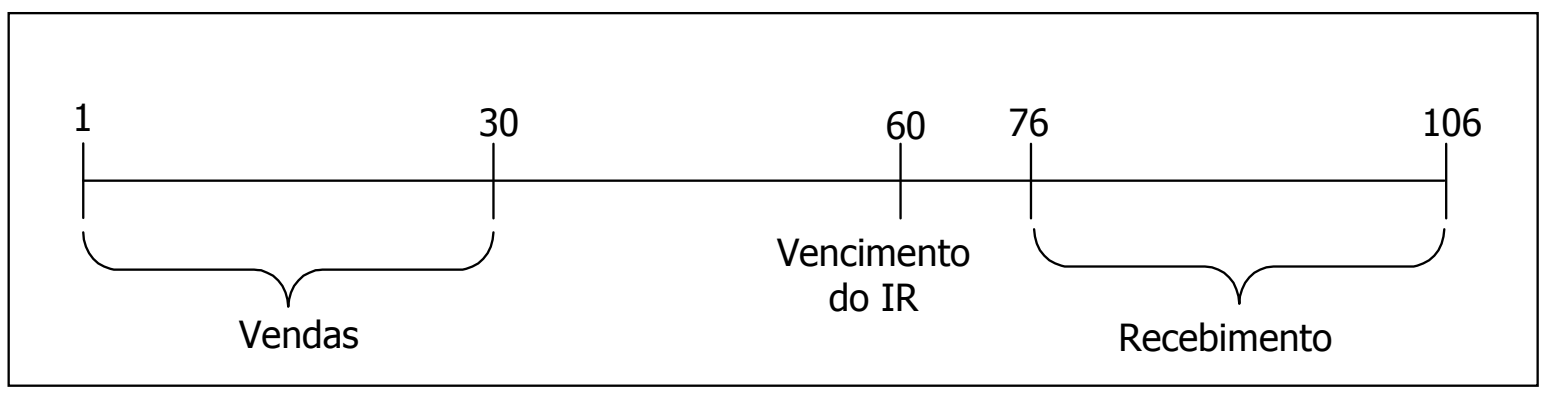

Supondo o mesmo exemplo anterior, na data de pagamento dos tributos nem as vendas do dia $1^{\circ}$ teriam sido recebidas, o que só vai acontecer no dia 76, 16 dias após o pagamento dos tributos referentes a essas vendas, como mostrado no quadro acima.

Isso é o que deve estar acontecendo com boa parte das empresas analisadas, pois apenas aquelas que tem PMRV menor ou igual a 30 é que terão recebido todas as vendas do período antes de pagar o IR.

Pode-se argumentar, entretanto, que os fornecedores financiam naturalmente esse tempo em que as vendas ainda não foram recebidas. Porém, para considerar isso, é necessário analisar todo o ciclo operacional que é financiado pelos fornecedores, o que inclui os estoques, e não apenas o PMRV. 
Assim, o índice a ser analisado é o Ciclo de Caixa. Nesse caso, o CO é de 149,2 dias em média, com um PMPF de 60,1 dias, resultando em um CC de 89,1 dias, superior ainda à média de PMRV.

Desse modo, verifica-se que as empresas podem ter custos mais elevados em função da necessidade de financiamento com capital de terceiros ou próprio para o pagamento dos tributos, em função do descompasso entre a ocorrência do fato gerador, que é por competência, e a sua realização em dinheiro.

\subsubsection{Princípios Contábeis Versus Critérios fiscais para CONTABILIZAÇÃo}

O lucro contábil, mensurado de acordo com os Princípios Contábeis Geralmente Aceitos, é utilizado como base para a distribuição de dividendos e de referência para a análise de desempenho da empresa por parte do mercado financeiro e de outros agentes econômicos.

Além disso, o lucro contábil tem sido a base de cálculo dos tributos diretos desde que foi instituído no Brasil.

O problema é que, na prática, a apuração do lucro contábil acaba seguindo, muitas vezes, critérios fiscais e não econômicos, como de fato deveria ser. Tais critérios fiscais são estabelecidos em lei e devem ser utilizados apenas para fins de apuração dos tributos. Porém, não são raras as ocasiões do dia-a-dia em que tais critérios acabam prevalecendo sobre os princípios 
contábeis e seus efeitos sendo mantidos na contabilização, muitas vezes modificando o resultado do período, base para a distribuição de dividendos.

São vários os casos em que a legislação tributária brasileira, notadamente a legislação do imposto de renda e da contribuição social, estabelece critérios para a contabilização das transações, entre os quais podemos dar como exemplo:

Tabela 2.2 - Princípios contábeis versus critérios fiscais

\begin{tabular}{|c|c|}
\hline is & Critérios Fiscais \\
\hline $\begin{array}{l}\text { Correção Monetária - o lucro deve } \\
\text { ser ajustado pelos ganhos ou perdas } \\
\text { com a inflação do período }\end{array}$ & $\begin{array}{l}\text { Correção Monetária - vedado } \\
\text { qualquer sistema de correção } \\
\text { monetária das demonstrações } \\
\text { contábeis (art. } 446 \text { do RIR/99) }\end{array}$ \\
\hline $\begin{array}{l}\text { Juros sobre Capital Próprio - } \\
\text { podem ser contabilizados como uma } \\
\text { forma de distribuição dos lucros } \\
\text { destinados aos proprietários }\end{array}$ & $\begin{array}{l}\text { Juros sobre Capital Próprio - } \\
\text { para serem dedutíveis, devem ser } \\
\text { contabilizados como despesa } \\
\text { financeira e se não ultrapassarem } \\
50 \% \text { dos lucros acumulados ou } \\
50 \% \text { do lucro do período (art. } 347 \\
\text { do RIR/99) }\end{array}$ \\
\hline & $\begin{array}{l}\text { ciação - deve ser efetuada } \\
\text { rdo com a vida útil e taxas } \\
\text { epreciação fixadas pela } \\
\text { aria da Receita Federal (art. } \\
\text { RIR/99) }\end{array}$ \\
\hline $\begin{array}{l}\text { Provisão para desvalorização de } \\
\text { estoques - na data do balanço, os } \\
\text { ativos devem ser avaliados pelo custo } \\
\text { ou pelo valor de mercado, dos dois o } \\
\text { menor, devendo ser reconhecida a } \\
\text { provisão para desvalorização, se for o } \\
\text { caso }\end{array}$ & $\begin{array}{l}\text { Avaliação dos estoques - não é } \\
\text { permitido reconhecer despesa } \\
\text { com provisão por ajuste a valor de } \\
\text { mercado, caso seja menor que o } \\
\text { custo de aquisição ou produção } \\
\text { (art. } 298 \text { do RIR/99) }\end{array}$ \\
\hline \begin{tabular}{|l} 
Provisão para \\
Duvidosos - deve ser reconhecida \\
para reduzir o valor das contas a \\
receber no montante das perdas \\
estimadas na cobrança e ajustar o \\
lucro do período, por competência
\end{tabular} & $\begin{array}{l}\text { Provisão para Devedores } \\
\text { Duvidosos - as perdas somente } \\
\text { são dedutíveis quando estiverem } \\
\text { de acordo com os critérios } \\
\text { especificados pela legislação, que } \\
\text { são bastante próximos da } \\
\text { completa impossibilidade de } \\
\text { cobrança (art. } 340 \text { do RIR/99) }\end{array}$ \\
\hline $\begin{array}{ll}\text { ovisão } & \text { para Co } \\
\text { le ser reconheci }\end{array}$ & \\
\hline
\end{tabular}


provável a ocorrência de um evento em que a provisão é constituída, futuro que resulte em perdas para a mas torna-se dedutível no entidade exercício em que a perda for paga ou efetivamente se realizar (art. 247 do RIR/99)

Assim, é possível observar que, seja para evitar fraudes ou abusos por parte do contribuinte, seja para atender a questões de política tributária, 0 governo acaba por interferir na forma de contabilização dos eventos, às vezes contrariando o seu sentido econômico.

É possível observar também que, como nos casos da depreciação e das provisões, tanto do lado do ativo como do passivo, o critério fiscal vai no sentido de evitar que essas provisões sejam constituídas de forma abusiva, no intuito de reduzir o imposto de renda a pagar. O controle dessa prática realmente é difícil, a não ser por imposição normativa ou por auditoria. Assim, ao invés de permitir que a despesa seja dedutível por competência, a norma tributária impõe que ela seja dedutível apenas quando estiver o mais próximo possível do seu efeito caixa.

O problema de as empresas utilizarem critérios fiscais como se fossem critérios contábeis está na distorção da informação contábil e na possibilidade de tornar as demonstrações enganosas ou parciais, voltadas apenas para o usuário governo. 


\subsubsection{Custos de Conformidade}

Os contribuintes, além do pagamento do próprio imposto, também precisam incorrer em gastos para apurar o valor do imposto e atender às obrigações acessórias.

Conforme pesquisa de Bertolucci e Nascimento ${ }^{2}$, verificou-se que no Brasil os custos necessários ao cumprimento das determinações legais tributárias por parte do contribuinte, os chamados Custos de Conformidade, são estimados em 0,75\% do PIB, o equivalente a R\$ 7,2 bilhões em 1999.

Esses custos de conformidade abrangem os gastos referentes à elaboração de demonstrações, declarações e outras informações ao fisco federal, estadual e municipal, ao cumprimento de alterações na legislação, a atendimento a fiscalizações, autuações e processos administrativos e judiciais.

Além da magnitude desses gastos, Bertolucci e Nascimento ${ }^{3}$ também mostram que os custos de conformidade são fortemente regressivos, o que penaliza mais as empresas menores, como se pode ver na tabela a seguir:

\footnotetext{
2 BERTOLUCCI, Aldo V. NASCIMENTO, Diogo T. Quanto custa pagar tributos?, p. 63.

${ }^{3}$ BERTOLUCCI, Aldo V. NASCIMENTO, Diogo T. Quanto custa pagar tributos?, p. 63.
} 
Tabela 2.3 - Custos de conformidade das companhias abertas

\begin{tabular}{|c|c|c|c|c|c|}
\hline \multicolumn{6}{|c|}{ CUSTOS DE CONFORMIDADE DAS COMPANHIAS ABERTAS } \\
\hline \multicolumn{6}{|c|}{ Incidência sobre o PIB } \\
\hline \multirow[b]{2}{*}{ Descrição } & \multicolumn{5}{|c|}{ Categorias de receita bruta (Milhões de reais) } \\
\hline & Até 100 & $\begin{array}{c}\text { De } 100 \mathrm{a} \\
1.000\end{array}$ & $\begin{array}{c}\text { De } 1.000 \\
\text { a } 5.000\end{array}$ & $\begin{array}{l}\text { De } 5.000 \\
\text { a } 15.000\end{array}$ & $\begin{array}{l}\text { Todas as } \\
\text { empresas }\end{array}$ \\
\hline Receita Bruta Total da categoria & 154 & 3.736 & 19.631 & 24.610 & 48.131 \\
\hline Custos internos de conformidade & 2,0 & 19,6 & 76,5 & 25,3 & 123,5 \\
\hline Custos externos de conformidade & 0,5 & 5,7 & 18,3 & 8,3 & 32,9 \\
\hline Custos totais de conformidade & 2,5 & 25,3 & 94,8 & 33,6 & 156,4 \\
\hline Economia prevista em caso de estabilidade de normas (\%) & $2,74 \%$ & $9,27 \%$ & $14,72 \%$ & $27,28 \%$ & $16,35 \%$ \\
\hline Valor adicionado FIBGE & 14.240 & 54.215 & 70.918 & 80.764 & 147.362 \\
\hline Valor da produção FIBGE & 49.964 & 150.951 & 183.381 & 141.571 & 341.787 \\
\hline Relação valor da produção - valor adicionado & 3,51 & 2,78 & 2,59 & 1,75 & 2,32 \\
\hline Custos de Conformidade sobre receita bruta (\%) & $1,66 \%$ & $0,68 \%$ & $0,48 \%$ & $0,14 \%$ & $0,32 \%$ \\
\hline Custos de Conformidade sobre o valor adicionado (PIB) (\%) & $5,82 \%$ & $1,88 \%$ & $1,25 \%$ & $0,24 \%$ & $0,75 \%$ \\
\hline Parcela do PIB correspondente aos Custos de Conformidade & 55.929 & 18.098 & 12.006 & 2.303 & 7.240 \\
\hline
\end{tabular}

Pelo lado do fisco, o sistema de tributação também envolve a incorrência de gastos, os chamados custos administrativos, que segundo Bertolucci e Nascimento ${ }^{4}$, representam:

"... os recursos do poder público destinados a legislar (Poder Legislativo), arrecadar e controlar (Poder Executivo) e julgar (Poder Judiciário) as questões relativas a tributos. Em um país federativo como o Brasil, esses custos são multiplicados por 27 estados e mais de 5.000 municípios".

No caso do Imposto de Renda, que é de competência da União, são também consumidos do mesmo modo recursos dos três poderes para arrecadálo.

\subsection{PROBLEMA}

Com base nessas observações a respeito do Imposto de Renda, surgiu a idéia de elaborar um modelo de tributação da renda nas empresas com base na geração de fluxos de caixa, ao invés da apuração com base no lucro.

\footnotetext{
${ }^{4}$ BERTOLUCCI, Aldo V. NASCIMENTO, Diogo T. Quanto custa pagar tributos?, p. 56.
} 
De maneira superficial, é possível supor que a realização dos fluxos de caixa aumenta a capacidade de pagamento do imposto de renda em relação à realização do lucro, uma vez que a geração de caixa indica a disponibilidade imediata de recursos para o pagamento dos tributos, o que nem sempre é verdade quando se trata de lucro.

A idéia não chega a ser nova. 0 trabalho de $\mathrm{King}^{5}$ desenvolve um modelo teórico de tributação por fluxos de caixa sob o ponto de vista da teoria econômica, e analisa o impacto de sua proposta sobre a estrutura de capital das empresas. No mesmo texto, o autor cita as contribuições de Brown (1948), King (1975), Kay e King (1978), Meade Committee (1978) e Aaron e Galper (1985).

Entretanto, há necessidade de elaborar uma proposta de modelo que leve em conta conceitos econômicos e contábeis, além de analisar se essa proposta efetivamente tem condições de melhorar a capacidade de pagamento da empresa, contribuir para o desenvolvimento das práticas contábeis, reduzir os custos de conformidade e verificar os possíveis impactos sobre a arrecadação.

Assim, o problema a ser investigado neste trabalho é o seguinte:

Quais os impactos da adoção de um modelo de tributação da renda baseado em fluxos de caixa realizados sobre a capacidade contributiva, as práticas contábeis, os custos de conformidade e a arrecadação?

\footnotetext{
${ }^{5}$ KING, Mervyn A. The cash flow corporate income tax, p. 377-400.
} 
É um problema que demanda investigação do ponto de vista teórico e prático, uma vez que será necessário verificar se o conceito de tributação pelos fluxos de caixa atende aos requisitos necessários para a tributação da pessoa jurídica, se isso é correto em termos econômicos e financeiros e se essa proposta é viável do ponto de vista prático.

O aprofundamento do estudo visa encontrar vantagens e desvantagens dos pontos de vista do fisco e do contribuinte, e desenvolver uma metodologia que potencialize as vantagens e reduza as desvantagens.

\subsection{OBJETIVO}

O objetivo desse estudo é demonstrar que o modelo de tributação por fluxos de caixa pode ou não ser implantado como forma de tributação das empresas.

\subsection{JUSTIFICATIVA}

A realização deste trabalho justifica-se pela necessidade de verificar se o modelo de tributação por fluxos de caixa pode ou não ser implantado como forma de tributação das empresas, como forma de reduzir os custos de conformidade, de melhorar a capacidade contributiva e reduzir a interferência da legislação tributária sobre as práticas contábeis.

Além disso, este trabalho justifica-se por outras três observações:

- Tendência de simplificação da sistemática de arrecadação; 
- Tendência, nos últimos anos, de a legislação tributária estar se aproximando do conceito de caixa;

- O modelo de tributação da pessoa física é baseado em caixa.

Essas três observações são analisadas a seguir.

\subsubsection{TendênCia de Simplificação da Sistemática de ARReCadação}

O governo tem demonstrado esforço no sentido de simplificar a sistemática de arrecadação dos tributos, principalmente quando se trata das pequenas empresas. Prova disso é a implementação do SIMPLES (Sistema integrado de pagamento de impostos e contribuições de microempresas e empresas de pequeno porte), calculado sobre o faturamento das micro e pequenas empresas.

Uma outra forma, que também pode beneficiar as pequenas empresas, é a sistemática do lucro presumido, em que se calcula o valor do imposto de renda sobre uma base presumida a partir do faturamento bruto.

O modelo de tributação por fluxos de caixa tende a ser mais simplificado que a tributação por lucro porque não envolve o uso de estimativas ou a necessidade de definição do momento de reconhecimento das receitas e das despesas para efeito de tributação. Além disso, por parte do fisco, o modelo de tributação em análise tende a ser menos custoso, uma vez que envolve o conceito de caixa realizado, menos sujeito a estimativas às vezes contestáveis. 


\subsubsection{Tendência de Aproximação do Conceito de Caixa}

Os critérios fiscais são estabelecidos levando-se em consideração a capacidade contributiva (como é o caso das atividades de longo prazo) e a realização efetiva das despesas.

Na maioria dos casos, as receitas são tributadas no momento em que a operação é realizada, mas em atividades de longo prazo a legislação permite que sejam tributadas no momento do recebimento.

Do mesmo modo, as despesas são normalmente dedutíveis no período de competência, mas há situações em que a legislação ordena que somente podem ser reduzidas da base de cálculo do tributo no momento em que forem efetivamente pagas ou que receitas não serão efetivamente recebidas.

É o caso da provisão para devedores duvidosos, como visto anteriormente, que deve ser reconhecida por competência, em confronto com as receitas obtidas no período. Porém, a legislação atual não permite que essa provisão, assim como algumas outras, possam ser deduzidas da base de cálculo dos tributos de acordo com sua competência, mas apenas quando se tornar claro (de acordo com a regra fiscal) que os títulos não serão recebidos.

Tanto pelo lado da receita, como da despesa, o fisco prefere, em determinadas ocasiões, que o reconhecimento ocorra o mais próximo de sua realização em caixa.

\subsubsection{O Modelo de Tributação da Pessoa física}


A tributação da Pessoa Física já é realizada em base caixa, embora esse modelo não possa ser perfeitamente transposto para a Pessoa Jurídica.

A Pessoa Física é tributada no recebimento da renda, muitas vezes na própria fonte pagadora, e lhe é permitido deduzir apenas alguns pagamentos, como os referentes a despesas médicas e com educação.

Há recebimentos que não são tributados por IR, tanto por não representarem renda (por exemplo, transferências patrimoniais de pai para filho), como por incentivo fiscal, como é o caso dos rendimentos de caderneta de poupança.

No caso de venda de imobilizado, a Pessoa Física deve pagar o imposto somente sobre o ganho de capital, ou seja, o que recebeu a mais em relação ao que lhe custou. Ainda assim, a tributação é realizada em base caixa, porque é efetuada no ato do recebimento pela venda, embora a dedução do valor de aquisição também ocorra nesse momento.

A tributação da Pessoa Física em base caixa é mais uma demonstração de que a Pessoa Jurídica também pode ser tributada dessa maneira e que é uma forma mais simplificada e direta de tributação.

\subsection{ORGANIZAÇÃO E DELIMITAÇÃO DO TRABALHO}

Para atingir o seu objetivo, o trabalho está organizado da seguinte forma:

- Capítulo 1 - Introdução; 
- Capítulo 2 - traz a caracterização do problema e a análise dos seus antecedentes e levanta sua justificativa;

- Capítulo 3 - desenvolve o conceito de renda, faz um paralelo entre renda e lucro e entre lucro e fluxo de caixa, para definir o que é fluxo de caixa tributável;

- Capítulo 4 - desenvolve em detalhes o modelo de tributação baseado em fluxos de caixa, com demonstrações numéricas;

- Capítulo 5 - levanta as implicações do modelo, analisando a capacidade contributiva, a prática contábil, os custos de conformidade e a arrecadação;

- Capítulo 6 - Conclusões.

O trabalho procura se manter dentro dos limites do problema colocado e os assuntos que estão relacionados. Assim, não serão tratados temas relacionados a outros tributos além do IR, a detalhes da legislação do IR que não contribuam para o desenvolvimento do modelo, ou a problemas diversos, como outras bases de cálculo para o IR ou outros aspectos do modelo que não os especificados neste capítulo.

Além disso, procurou-se tomar como base a legislação brasileira atual, mais para efeito de referência prática do que como referencial de ideal ou por talvez ser apenas aplicável ao caso brasileiro. Procurou-se desenvolver um modelo que possa ser aplicado a qualquer economia capitalista.

O trabalho está baseado em pesquisa e análise bibliográfica e em estudos estatísticos a partir de dados secundários obtidos em software com base de dados oriundos de relatórios contábeis. 


\section{FLUXOS DE CAIXA TRIBUTÁVEIS}

\subsection{INTRODUÇÃO}

Este capítulo procura identificar o lucro tributável e os fluxos de caixa tributáveis e estabelecer bases para a estruturação do modelo de tributação com base nos fluxos de caixa, sob o ponto de vista teórico. Para isso, serão investigados assuntos que possam conduzir a essa identificação: a tributação sobre a renda, a consideração do lucro como renda, fluxo de caixa como renda e os fluxos que deveriam ser tributados.

\subsection{TRIBUTAÇÃO SOBRE A RENDA}

Este tópico procura tratar da questão da tributação sobre a renda, quais são seus pontos positivos e negativos e por que ela existe.

\subsubsection{O Apelo da Tributação sobre a Renda}

De acordo com Harberger ${ }^{6}$, a tributação da renda de empresas se tornou uma das maiores fontes de receita fiscal na maioria dos países. No Brasil não é

\footnotetext{
${ }^{6}$ HARBERGER, Arnold C. Taxation and welfare, p. 122.
} 
diferente. Segundo dados da Secretaria da Receita Federal ${ }^{7}$, a arrecadação de Imposto de Renda em 1999 foi de $R \$ 51,5$ bilhões, 34\% de tudo o que foi arrecadado pela União. Somados à Contribuição Social sobre o Lucro, que também é um tributo sobre a renda, o percentual sobre a arrecadação sobe para $40,49 \%$.

Sob o ponto de vista do governo, o imposto de renda é interessante em termos de viabilidade administrativa e popularidade política. É o que argumenta Harberger ${ }^{8}$ quando fala dos pontos positivos dessa espécie de tributo:

"É altamente viável administrativamente porque a lei sob a qual as empresas são constituídas geralmente exige a manutenção das contas em bases padronizadas; assim, o cumprimento do imposto se reduz aos problemas de exigir contas honestas $e$ corretas e de resolver uma série de assuntos técnicos, como a determinação de quais gastos devem ser despesas ou devem ser capitalizadas, e a determinação de taxas adequadas de depreciação para classes específicas de ativos. Esses problemas têm sido tratado na maioria dos países por decretos administrativos ou regulamentos editados pelas próprias autoridades fiscais, operando sob ambos guias expostos na legislação fiscal".

Assim, para Harberger, a viabilidade administrativa do imposto de renda está na facilidade da forma de se impor regras para a apuração do imposto e a possibilidade de se utilizar a contabilidade, exigida pela legislação civil e comercial, como base para essa apuração.

7 Estrutura tributária federal - impostos e contribuições. Secretaria da Receita Federal. Disponível em <http://www.receita.fazenda.gov.br>. Acesso em 15 jul. 2002.

${ }^{8}$ HARBERGER, Arnold C. Taxation and welfare, p. 122. 
Ainda de acordo com a argumentação de Harberger ${ }^{9}$, o imposto de renda tem duas características de forte apelo político.

Primeiro, o imposto está de acordo com a concepção popular de capacidade de pagamento, partindo do pressuposto de que as entidades possuem e geram riqueza.

Em segundo lugar, o imposto de renda das empresas, por definição, não pode ser uma fonte de prejuízo para a empresa. Aquelas empresas que não têm lucro não pagam imposto de renda; somente empresas 'lucrativas' devem arcar com o imposto. Outras formas de taxar os negócios poderiam ser responsáveis por tornar o que seria uma situação de lucro líquido em prejuízo líquido. Empresas em uma situação difícil iriam provavelmente preferir uma taxação do lucro líquido a outras formas de taxação do negócio, e fortes oponentes da taxação da renda provavelmente seriam as empresas mais lucrativas com maior capacidade de contribuição.

\subsubsection{Histórico e Origens}

De acordo com Lemke ${ }^{10}$, há quem diga que já em Roma e Atenas da Era Antiga existia o imposto sobre a renda. Outros afirmam que ele surgiu em Florença sob o nome de Decima Scalata. Porém, todos concordam que a

\footnotetext{
${ }^{9}$ HARBERGER, Arnold C. Taxation and welfare, p. 123.

${ }^{10}$ LEMKE, G. Imposto de Renda - os conceitos de renda e de disponibilidade econômica e jurídica, p. 13.
} 
história do moderno imposto de renda teve início na Inglaterra, no século XIX, com o nome de Income Tax.

Principalmente após a Primeira Guerra Mundial, o imposto de renda foi se espalhando para a legislação de outros países, até se tornar um imposto universal.

Ainda de acordo com Lemke ${ }^{11}$, no Brasil, a tributação sobre a renda existe desde o Império, mas apenas em 1922 ele passou a incidir sobre todos os rendimentos de pessoas físicas e jurídicas. Ao longo do tempo, foram-se aperfeiçoando os critérios de personalidade e progressividade, os sistemas de cobrança e fiscalização, a criação do IR na fonte e o reconhecimento da inflação.

A evolução e a continuidade de sua cobrança, ao longo dos tempos, só vêm reafirmar o argumento de Harberger de viabilidade administrativa e popularidade política do imposto sobre a renda.

\subsubsection{Críticas à tributação sobre A Renda}

Apesar das vantagens apontadas da tributação sobre a renda, há também desvantagens. Harberger ${ }^{12}$ sustenta que o imposto sobre a renda apresenta problemas em termos econômicos:

\footnotetext{
${ }^{11}$ LEMKE, G. Imposto de Renda - os conceitos de renda e de disponibilidade econômica e jurídica, p. 14.

${ }^{12}$ HARBERGER, Arnold C. Taxation and welfare, p. 123.
} 
"As vantagens politicas e administrativas do imposto de renda das empresas, entretanto, não implicam que é um bom imposto do ponto de vista econômico. Muito pelo contrário, é facilmente demonstrável que, da maioria das fontes de receita, esse imposto é um dos menos justificáveis no campo econômico. Ele leva a uma discriminação essencialmente arbitrária entre indústrias ou atividades, tende a inibir o crescimento de setores mais dinâmicos da economia, e provavelmente causa uma redução na taxa geral de formação de capital".

O mesmo autor ainda aponta os motivos do efeito discriminatório do imposto:

"Todas as características discriminatórias do imposto de renda das empresas vêm do fato de que o lucro líquido é a base do imposto. Por definição do imposto, todas as atividades informais são isentas; e mesmo dentro do setor formal da economia, o imposto pesa mais nas atividades com baixas taxas de endividamento (porque os juros sobre passivos são despesas dedutíveis). A conseqüência dessa discriminação é uma distorção da estrutura econômica, favorecendo a economia informal sobre as atividades formais e, dentro do setor formal, as distorções favorecendo mais aquelas atividades que podem ser facilmente financiadas em grande escala por capital de terceiros do que as que não't3.

Essas críticas de Harberger ao imposto de renda podem ser resumidas em duas:

- ele não é capaz de abranger as atividades da economia informal e

- há o favorecimento de empresas com maior endividamento, por causa da dedutibilidade das despesas financeiras.

Em ambas, o autor evidencia pontos que realmente revelam distorções do ponto de vista econômico, mas que acabam existindo em função da estrutura de apuração do imposto, baseada em registros contábeis de empresas

\footnotetext{
${ }^{13}$ HARBERGER, Arnold C. Taxation and welfare, p. 123.
} 
estabelecidas formalmente, e em função da possibilidade de dedução das despesas financeiras.

Partindo do pressuposto de que o imposto de renda deve permanecer como instrumento de financiamento do Estado, dada sua existência solidificada em todo o mundo em virtude de sua viabilidade administrativa e popularidade política, é importante aperfeiçoar seu sistema de cobrança, procurando minimizar seus problemas.

A informalidade das atividades se reduz com incentivos à formalização, tanto por meio de penalizações à informalidade, como por redução da carga tributária e pela redução de obrigações acessórias.

Em relação ao favorecimento de empresas que conseguem se financiar mais com capital de terceiros, será feita adiante uma análise mais aprofundada sobre 0 assunto.

A respeito de política econômica, Rezende ${ }^{14}$ também aponta uma distorção do Imposto de Renda:

"Especialmente no caso de países subdesenvolvidos, o aspecto mais importante das possíveis distorções que o uso do Imposto sobre a Renda como instrumento de política econômica provoca, do ponto de vista de critérios de justiça fiscal, referese ao efeito dos incentivos à poupança. Admitindo que a insuficiência de poupança constitui-se numa das principais restrições ao aumento do nível de renda em países de menor nível de desenvolvimento, uma das preocupações importantes de política econômica consiste em promover um aumento dos recursos disponíveis para investimentos. Nessas condições, os princípios de justiça fiscal poderiam ser conflitantes com os objetivos de maximização do crescimento econômico, à medida

\footnotetext{
${ }^{14}$ REZENDE, Fernando A. Finanças públicas, p. 185.
} 
que uma maior progressividade na tributação concorresse para reduzir a poupança global".

A essas críticas, acrescentamos uma: a dificuldade prática de ter o lucro contábil como base de cálculo do imposto, como foi discutido no Capítulo 1.

\subsection{RENDA}

Ao tratar de imposto sobre a renda, é importante analisar mais detidamente o conceito de renda, para posteriormente verificar o que deveria ser considerado como renda tributável, porque este conceito tem sido objeto de controvertidas, e por vezes contraditórias, análises.

Primeiramente, vamos levantar os conceitos jurídicos de renda, e posteriormente os conceitos econômicos e contábeis.

\subsubsection{Conceitos JURÍdicos DE RENDA}

Os conceitos jurídicos de renda são baseados nos princípios de tributação e consubstanciados na Lei.

O Código Tributário Nacional (CTN) estabelece sua definição de renda quando trata do fato gerador do imposto de renda:

"o imposto de renda e proventos de qualquer natureza tem como fato gerador a aquisição da disponibilidade econômica ou jurídica: I - de renda assim entendido o produto do capital, do trabalho ou da combinação de ambos; II - de proventos de 
qualquer natureza, assim entendidos os acréscimos patrimoniais não compreendidos no inciso anterior".

Conforme Ichihara ${ }^{15}$, o imposto de renda inclui em sua definição de fato gerador:

"(...) rendas de capital, do trabalho e da combinação de ambos, por exemplo, juros, aluguel, salários e honorários profissionais, que exijam trabalho e emprego de materiais etc., além de proventos de qualquer natureza, que nada mais são do que os acréscimos patrimoniais não incluídos no conceito de renda, por exemplo, os proventos de aposentadoria, recebimento de doações etc."

Dessa definição, entende-se que há dois conceitos envolvidos: renda e proventos. Como analisa Machado ${ }^{16}$ :

"Na expressão do Código, renda é sempre um produto, um resultado, quer do trabalho, quer da combinação desses dois fatores. Os demais acréscimos patrimoniais que não se comportem no conceito de renda são proventos".

Isso significa que a lei pode estabelecer, expressa ou implicitamente, 0 que pode ser diminuído do que foi auferido na determinação desses acréscimos patrimoniais.

Em relação à aquisição de disponibilidade econômica ou jurídica, o CTN quer dizer que a renda e os proventos podem ser pagos (disponibilidade econômica) ou creditados, uma vez que a disponibilidade jurídica ocorre quando o contribuinte passa a juridicamente dispor do valor, embora este ainda não esteja na forma de dinheiro em suas mãos.

\footnotetext{
${ }^{15}$ ICHIHARA, Yoshiaki. Direito tributário, p. 213.

${ }^{16}$ MACHADO, Hugo de Brito. Curso de direito tributário, p. 274.
} 
Isso tem relação com o conceito de competência contábil, uma vez que o reconhecimento das receitas (e a confrontação das despesas) ocorre no momento em que são ganhas, não necessariamente quando do recebimento.

Apesar de o legislador ter à sua disposição a possibilidade de adotar uma definição própria de renda, não é possível ignorar por completo a existência de conceitos econômicos de renda, como coloca Lemke ${ }^{17}$ :

"A legislação fiscal não está jungida à adoção do conceito de renda das teorias econômicas. (...) Isso não significa, porém, que a Ciência Jurídica deva ignorar completamente a existência de conceitos econômicos de renda. Sobretudo o legislador ordinário não pode fazê-lo, pois o pressuposto das normas tributárias é a existência de riqueza, conceito este estudado pela Economia, sendo a renda um de seus índices. Como parâmetro para as normas jurídicas, são fundamentais, portanto, as teorias econômicas sobre a renda".

Da mesma forma argumenta Machado ${ }^{18}$ :

"É certo que o legislador goza de uma liberdade relativa para formular o conceito de renda. Pode escolher entre os diversos conceitos fornecidos pela Economia, procurando alcançar a capacidade contributiva e tendo em vista considerações de ordem prática. Não pode, todavia, formular arbitrariamente um conceito de renda ou de proventos".

Desse modo, não é possível dizer que há um conceito genuíno do Direito sobre renda. O que há são as definições impostas pela legislação, que não podem deixar de seguir os conceitos econômicos de renda.

17 LEMKE, G. Imposto de Renda - os conceitos de renda e de disponibilidade econômica e jurídica, p. 29.

${ }^{18}$ MACHADO, Hugo de Brito. Curso de direito tributário, p. 274. 


\subsubsection{Conceitos EConômicos de RendA}

Um dos primeiros economistas a tratar do conceito de renda foi Adam Smith, que se baseou nos fatores de produção. De acordo com a leitura de Lemke $^{19}$ :

"Adam Smith afirma que renda é uma riqueza nova que deriva de uma fonte produtora. Em sentido amplo, renda é a soma do que se recebe como contraprestação do trabalho (salário); através do uso do capital (ganho); por meio da entrega do capital para o uso de terceira pessoa (juro) e também como resultado da exploração da terra (renda em sentido estrito). Renda líquida é aquela que sobra para o proprietário da terra depois de deduzidos todos os custos da produção. Para esse autor, a renda não inclui os bens imateriais nem os serviços. Não inclui também os serviços derivados do uso dos bens de propriedade do indivíduo".

Já Fischer ${ }^{20}$ apresenta uma abordagem conceitual de renda sob um outro enfoque:

"Capital é um fundo e renda é um fluxo. (...) Capital é riqueza, e renda é o serviço da riqueza. (...) O estoque de riqueza existente em um instante de tempo é chamado de capital. Um fluxo de serviços durante um período de tempo é chamado de renda".

19 LEMKE, G. Imposto de Renda - os conceitos de renda e de disponibilidade econômica e jurídica, p. 17.

${ }^{20}$ FISCHER, Irving. The nature of capital and income, p. 52. 
Lemke $^{21}$ faz considerações adicionais sobre o conceito de Fisher e seus entendimentos sobre renda:

"Na opinião de Fisher, a renda corresponde ao total dos serviços recebidos por uma pessoa, incluindo aqueles derivados dos bens de sua propriedade. Ele exclui do conceito de renda o valor do dinheiro reinvestido. Renda, para esse autor, é o fluxo de serviços durante um certo período de tempo. Capital é a reserva de riqueza existente num determinado momento. Sustenta ele, ainda, a irrelevância do requisito da periodicidade da renda. Apesar disso, entende que as heranças e doações não constituem renda, porque através delas se adquire direito ao capital, e não ao serviço do capital".

Hicks também analisou a questão do conceito de renda e chegou ao seguinte conceito:

"... a renda de uma pessoa é valor máximo que ela pode consumir durante uma semana e ainda espera estar, no final da semana, tão bem como estava no começo ${ }^{122}$.

Basicamente, esse conceito trata a renda como aquilo que pode ser consumido sem afetar o patrimônio, ou simplesmente a diferença entre dois patrimônios. Porém, há outras considerações a fazer sobre esse conceito.

Hicks faz uma análise pormenorizada de seu conceito, analisando a questão do consumo e sua diferença para gasto:

"Estritamente falando, poupança não é a diferença entre renda e despesa, é a diferença entre renda e consumo. Renda não é a quantia máxima que o indivíduo pode 'gastar' quando espera

\footnotetext{
${ }^{21}$ LEMKE, G. Imposto de Renda - os conceitos de renda e de disponibilidade econômica e jurídica, p. 17.

${ }^{22}$ HICKS, J.R. Value and capital, p. 172.
} 
estar no final da semana na mesma situação boa que antes; éa quantia máxima que pode 'consumir' ${ }^{\prime 23}$.

A diferença entre 'despesa' e 'consumo' faz referência ao que entendemos em contabilidade por regime de competência. Da forma como coloca Hicks, a 'despesa' significa desembolso, ou saída de caixa. O indivíduo pode fazer desembolsos acima ou abaixo do que poderia consumir na semana. Ele estaria poupando se o seu consumo estivesse abaixo da renda, ou estaria consumindo seu patrimônio se a renda fosse menor que o consumido no período. Isso não tem necessariamente correspondência com 0 valor desembolsado no mesmo período, uma vez que a saída de caixa pode ter ocorrido com um ativo que não tenha sido consumido inteiramente durante o período. Por outro lado, pode ser que o ativo já tenha sido adquirido no passado e esteja sendo consumido em parte no próprio período; nesse caso, 0 valor consumido seria maior que o desembolsado no período, gerando teoricamente uma sobra que não representa renda. Isso é regime de competência, com a alocação do consumo dos recursos aos períodos que beneficia.

\footnotetext{
${ }^{23}$ HICKS, J.R. Value and capital, p. 176.
} 


\subsection{LUCRO E RENDA}

\subsubsection{RelaÇão entre Renda e LuCRO}

Hicks, ao estabelecer seu conceito de renda, estava preocupado com a utilidade prática do mesmo para os indivíduos, e colocou o seguinte:

"o objetivo do cálculo da renda em termos práticos é dar às pessoas uma informação sobre a quantidade que podem consumir sem se empobrecerem. Levando essa idéia às últimas conseqüências, parece que deveríamos definir renda de um indivíduo como o valor máximo que ele pode consumir durante uma semana e ainda esperar que sua situação econômica no final da semana seja a mesma do começo da semana. Desse modo, se uma pessoa poupa, ela planeja estar numa situação econômica melhor no futuro; quando gasta mais que o equivalente a essa renda, planeja ficar numa situação pior. Lembrando que o objetivo prático da renda é servir de guia para uma conduta prudente, acho que é claro ser esse o seu significado central ${ }^{24}$.

É possível observar que o autor estava se referindo a um indivíduo, 'gente de carne e osso', e não a uma empresa ou qualquer outra entidade.

A transposição desse conceito, que é voltado aos indivíduos, para a avaliação da renda da empresa, requer uma análise mais profunda do que a que se tem feito em Contabilidade, em que geralmente se entende a renda da empresa como o próprio lucro.

Na Contabilidade, o indivíduo e a empresa, assim como o governo ou a entidade sem fins lucrativos, são seus objetos de observação, tratados

\footnotetext{
${ }^{24}$ HICKS, J.R. Valor e capital, p. 144.
} 
indistintamente, como se fossem organismos independentes. Iudícibus ${ }^{25}$ define a entidade contábil como "todo ente (envolvendo as mais variadas graduações de tamanho) capaz de gerir recursos e agregar utilidade (em sentido amplo)". Assim, uma entidade pode ser uma empresa ou um grupo de empresas, um departamento da empresa ou simplesmente uma atividade. O Postulado da Entidade nasceu do propósito de separar a figura do proprietário da de seu negócio, mas consegue ser mais amplo por justamente considerar a existência de uma entidade, qualquer que seja a sua forma, e permitir à Contabilidade 'enxergá-la' separadamente das demais com que esteja relacionada.

Entretanto, o que surgiu como uma maneira de se observar melhor a entidade, acabou por levar a uma certa confusão em relação ao que é a renda, para os contadores, porque era necessário definir a renda obtida pela empresa, separadamente da de seus proprietários.

Para mostrar a confusão, tomemos a seguinte citação provinda de Solomons, no trabalho de Guerreiro ${ }^{26}$ :

"para usar a definição de lucro de Hicks para uma entidade de negócio ao invés de para um indivíduo, nós precisamos somente modificá-la levemente: o lucro do negócio, se ele é incorporado como uma entidade legal, separada ou não, é a quantia pela qual seu patrimônio líquido aumentou durante $o$ período, devida permissão sendo feita para qualquer novo capital contribuído pelos seus donos ou para qualquer distribuição feita pela empresa para seus proprietários".

\footnotetext{
${ }^{25}$ IUDÍCIBUS, Sergio de. Teoria da Contabilidade, p. 48.

${ }^{26}$ SOLOMONS, David. Economic and accounting concepts of income. P. 376. IN: GUERREIRO, Reinaldo. Mensuração do resultado econômico, p. 4.
} 
Por esse raciocínio, o lucro (ou melhor, a renda de Hicks, traduzida como lucro) seria a diferença entre dois patrimônios líquidos do negócio. Porém, vejase a incoerência: se o lucro é a diferença de dois PL's, um aumento de capital também seria lucro. É por isso que Solomons faz sua 'devida permissão'. É uma regra que já contém em si uma exceção...

Chang ${ }^{27}$ também procura transpor o conceito de renda de Hicks para o caso das empresas, no mesmo raciocínio de Solomons, colocando que a renda da empresa é o que entendemos como o lucro dos proprietários:

"... a partir dessa noção central, nós derivamos a definição da renda da empresa como a quantia máxima que a firma pode distribuir como dividendos e ainda espera estar tão bem no final do período como ela estava no começo".

Na forma como é colocada a definição de Chang há um outro problema: como a renda da empresa pode ser algo que não é dela, e sim de seus proprietários, na forma de dividendos?

Para ampliar a discussão: se levarmos 'ao pé da letra' o conceito de Hicks, aplicando-o à empresa e levando em conta a Teoria da Entidade ${ }^{28}$, poderíamos erroneamente entender a renda como sua receita, porque esse é o valor que poderia ser consumido por ela (em forma de despesas) sem alterar

${ }^{27}$ CHANG, E. C. Business income in accounting and economics. Accounting Review, oct. 1962, p. 639.

${ }^{28}$ Por essa teoria, a entidade é vista como tendo existência separada, independente das vidas de seus organizadores, fundadores ou proprietários. 
seu patrimônio líquido. Nesse sentido, o eventual lucro seria sua 'poupança', o valor da renda que estaria acima do seu consumo.

Para trazer um pouco de luz a essa questão, é necessário recorrer novamente à economia.

Em termos macroeconômicos, os indivíduos têm o seu papel, exercem uma função que não se confunde com o exercido pelas empresas.

Em Macroeconomia, se considera como o agregado dos indivíduos o que se chama de famílias. Sachs e Larrain ${ }^{29}$ explicam o Fluxo Circular da Renda, um entendimento básico para o cálculo do Produto Interno Bruto (PIB):

"As familias demandam a produção das empresas e também oferecem os insumos de mão-de-obra e capital para as empresas. Por sua vez, as empresas fabricam os produtos vendidos para as famílias, e o resultado das vendas é usado para pagar os trabalhadores e o capital necessário".

É como mostra a figura apresentada pelos mesmos autores ${ }^{30}$ :

Figura 3.1 - 0 fluxo circular da renda

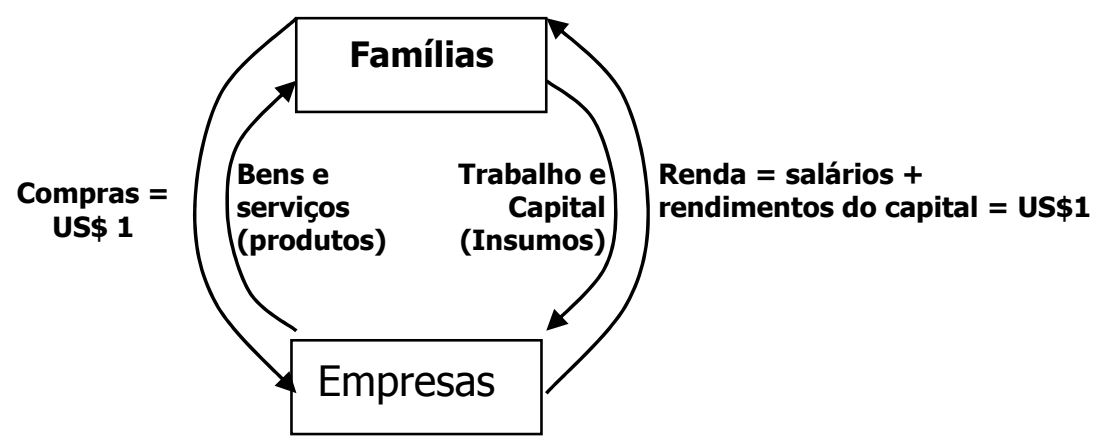

\footnotetext{
${ }^{29}$ SACHS, Jeffrey D. LARRAIN B, Felipe. Macroeconomia, p. 23.

${ }^{30}$ SACHS, Jeffrey D. LARRAIN B, Felipe. Macroeconomia, p. 24.
} 
Isso significa que, no agregado da economia, as empresas recebem trabalho e capital das famílias que, por sua vez, recebem salários, aluguéis, juros e os lucros das empresas. Salários e rendimentos do capital são a renda das famílias produzida pelas empresas.

O PIB é uma medida de geração de riqueza da economia porque há uma identidade nesse fluxo circular:

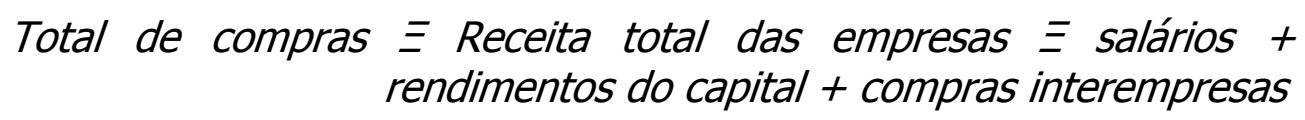

O total de compras inclui as realizadas pelos consumidores finais do produto e as realizadas por empresas que usam os produtos de outras empresas como insumos para fabricar seus próprios produtos. Se subtrairmos as compras interempresas, obtemos outra identidade:

\section{Demanda final ミ valor adicionado ミsalários + rendimentos do capital}

A partir dessa identidade, pode-se ver o PIB de três formas, conforme Sachs e Larrain $^{31}$ :

- pelo método do dispêndio, que corresponde ao somatório das demandas finais, o que inclui o consumo familiar, o consumo governamental, o investimento em novo capital na economia, e exportações menos importações;

- pelo método do valor adicionado, em que se soma o valor adicionado produzido em cada um dos setores da economia;

\footnotetext{
${ }^{31}$ SACHS, Jeffrey D. LARRAIN B, Felipe. Macroeconomia, p. 24-6.
} 
- pela soma dos rendimentos dos fatores (trabalho e capital) que contribuem para o processo de produção.

Desse modo, o PIB pode ser visto por três ópticas: a do consumo, a do valor adicionado e a da renda. Relacionando isso com o fluxo circular da renda visto anteriormente, faltaria apenas a "seta" dos insumos (trabalho e capital) ofertados pelas famílias, mas o trabalho não tem expressão monetária que permita ser medido.

Nesse momento, nos interessa a "seta" da renda. Observa-se que ela é o fluxo de salários e rendimentos do capital que parte das empresas em direção às famílias. Aparentemente óbvio, mas ilustra uma coisa importante: a renda da economia não tem como destino as empresas, ou seja, elas não são beneficiárias de renda.

Disso tudo, podemos chegar à seguinte observação: as empresas não obtêm renda; elas são geradoras de renda. A renda é obtida pelas famílias, com o emprego de capital e trabalho nas empresas.

Isso leva à conclusão de que não se deve falar em renda da empresa, mas sim em renda gerada pela empresa para os detentores do capital e do trabalho. Renda, portanto, é o valor gerado pela empresa que remunera o capital e o trabalho empregados pelos indivíduos. O lucro é renda, mas não da empresa, e sim para seus investidores.

O Postulado da Entidade ajuda na separação contábil entre empresa e proprietário e demais entidades, mas não permite a explicação de o que seja renda, uma vez que ela não é da entidade empresa, e sim por ela gerada para 
os detentores de capital e trabalho. É um conceito de relacionamento entre partes, e não de separação.

Para determinar a renda dos proprietários provinda da empresa, é necessário apurar o lucro dela que lhes é destinado. Ainda assim, poderíamos não estar apurando toda a renda dos indivíduos que são proprietários, uma vez que eles podem estar auferindo também rendas de outras naturezas, como salários. Desse modo, o lucro da empresa é a parcela da renda do indivíduo obtida com o seu investimento nela.

Se fôssemos adaptar o conceito de Hicks para as empresas, teríamos que colocar nos seguintes termos: a renda gerada pela empresa é o que os indivíduos, que nela investiram capital e trabalho, podem consumir durante uma semana e ainda esperam estar, no final da semana, tão bem como estavam no começo. Essa adaptação preserva o sentido que Hicks quis dar de renda do indivíduo, além do aspecto do consumo, que demanda sua apuração em base competência.

O que muda com essa conclusão é que a renda não é a diferença entre dois patrimônios líquidos da empresa, como interpretou Solomons. A renda gerada pela empresa abrange os salários e todos os rendimentos do capital, e não apenas lucro. A renda dos investidores também não é a diferença de dois PL's da empresa, porque o seu PL pode variar não apenas com lucro, mas também com aumentos de capital, por exemplo. A renda dos investidores é a diferença entre dois investimentos realizados pelos indivíduos na empresa. 
Renda também não é a receita da empresa, como poderíamos interpretar a partir do conceito de Hicks e da teoria da entidade, porque a empresa não obtém renda, mas sim gera renda. Receita é a expressão monetária dos produtos destinados aos compradores (consumidores e intermediários). Além disso, a receita não poderia ser a renda, porque a empresa não efetua consumos, na acepção econômica da palavra - seus gastos são na forma de insumos adquiridos de outras empresas, para o pagamento de salários, juros sobre empréstimos e renda aos sócios. Quando uma empresa participa em outra, os dividendos a que tem direito também não são sua renda, mas eles aumentam seu lucro que, por sua vez, será a renda de seus investidores, se estes forem indivíduos.

Não há invalidação do Postulado da Entidade com isso, porque a Contabilidade deve continuar avaliando o patrimônio da empresa de forma separada do de seus investidores, pois do contrário não seria possível apurar a renda gerada somente pela empresa.

Muda também com essa conclusão o entendimento de o que deve ser renda tributável e sua diferença para lucro tributável, como será analisado mais adiante.

\subsubsection{COMPOSIÇÃO DO LUCRO}

Se a mensuração da renda serve para que os indivíduos saibam o quanto eles podem consumir sem se empobrecerem, a mensuração do lucro da 
empresa serve para se saber o valor da parcela de renda do indivíduo que é proveniente do seu investimento na empresa.

Entretanto, foi-se descobrindo que o lucro também servia como uma medida de eficiência da aplicação do capital na atividade. Verificou-se também que essa eficiência deve ser medida após o desconto do custo de oportunidade, ou seja, o retorno do capital aplicado só é verdadeiramente eficiente se for acima do que seria se o mesmo recurso fosse aplicado em outra alternativa de investimento de risco equivalente. Daí, muitos consideram que o verdadeiro lucro é somente aquele descontado do custo do capital próprio. Com enfoque diferente, outros consideram que o lucro deve representar o valor agregado pela empresa dentro de sua cadeia produtiva, por ser mais amplo e não considerar apenas a figura do proprietário.

Assim, o lucro pode assumir valores diferentes de acordo com o propósito da informação, dependendo de sua composição e da metodologia de mensuração do patrimônio.

Isso não significa que a renda do investidor também possa ter diferentes composições, embora possa ter valores diferentes em função da metodologia de mensuração do patrimônio. A renda do investidor é todo o valor gerado pelo investimento dos proprietários e que pode ser pago a eles, independentemente de qualquer composição que o lucro possa assumir. O lucro é um conceito econômico e mensurado pela contabilidade, e como tal faz parte do seu sistema de informações, que pode acabar assumindo estruturas diferentes dependendo do seu usuário. 
Em relação à composição do lucro, vamos dar um exemplo: suponha uma empresa que tenha um Capital de $\$ 10.000$ e lucros acumulados de $\$ 1.500$ em um dado momento:

Tabela 3.1 - Patrimônio Líquido Inicial

\begin{tabular}{|l|r|}
\hline Capital & 10.000 \\
\hline Lucros Ac. & 1.500 \\
\hline TOTAL & 11.500 \\
\hline
\end{tabular}

Periodicamente, ela aufere lucros contábeis líquidos de $\$ 1.500$ e paga dividendos de $\$ 500$ no período seguinte. Desse modo, podemos demonstrar a variação do PL do segundo período, por meio de uma Demonstração das Mutações do Patrimônio Líquido (DMPL):

Tabela 3.2 - DMPL com Lucro Líquido

\begin{tabular}{||l|r|r||}
\hline \multicolumn{3}{|c|}{ DMPL } \\
\hline & Capital & Lucros Ac. \\
\hline Saldo Inicial & 10.000 & 1.500 \\
\hline Pagto. Dividendos & & $(500)$ \\
\hline Lucro do Período & & 1.500 \\
\hline Saldo Final & 10.000 & 2.500 \\
\hline
\end{tabular}

Assim, o PL final fica do seguinte modo:

Tabela 3.3 - Patrimônio Líquido Final

\begin{tabular}{|l|l|}
\hline PL Final \\
\hline Capital & 10.000 \\
\hline Lucros Ac. & 2.500 \\
\hline TOTAL & 12.500 \\
\hline
\end{tabular}

Perceba que a renda proporcionada pela empresa aos investidores no período é de $\$ 1.500$, que nesse caso coincide com o lucro do período, mesmo com uma variação do $\mathrm{PL}$ de $\$ 1.000$. O pagamento dos dividendos é 
simplesmente a realização financeira de parte da renda obtida pelos investidores no período anterior.

Vamos supor agora que a definição utilizada para o lucro seja o de Valor Adicionado $^{32}$, considerando que os beneficiários do lucro não sejam apenas os acionistas, mas também o governo, os fornecedores de capital e os funcionários. Com isso, o PL passa a ser mensurado de forma diferente: o lucro acumulado anterior do mesmo exemplo deixa de contemplar as distribuições a esses beneficiários, que são feitas no período seguinte. Supondo que os pagamentos ao governo, aos emprestadores, aos funcionários e aos acionistas sejam de $\$ 500$ para cada um, o lucro acumulado anterior seria de $\$ 3.000$ $(\$ 1.500+500 \times 3)$, porque o lucro do período que o formou não considerava essas distribuições. Dentro do período atual, tivemos esses pagamentos, mais um lucro líquido de $\$ 3.000$, que correspondem aos mesmos $\$ 1.500$ de lucro da outra forma, com as distribuições. Assim, a demonstração fica da seguinte forma:

${ }^{32}$ É o valor adicionado pela empresa dentro de sua cadeia produtiva, representado pela diferença entre as receitas obtidas e os gastos com bens e serviços adquiridos de seus fornecedores. 
Tabela 3.4 - Variação do PL com Lucro Medido pelo Valor Adicionado

\begin{tabular}{|l|r||l|r|r||l|r|}
\hline \multicolumn{2}{|c|}{ PL Inicial } & \multicolumn{3}{c||}{ DMPL } & \multicolumn{2}{c|}{ PL Final } \\
\hline Capital & 10.000 & & Capital & Lucros Ac. & Capital & 10.000 \\
\hline Lucros Ac. & 3.000 & Saldo Inicial & 10.000 & 3.000 & Lucros Ac. & 4.000 \\
\hline TOTAL & 13.000 & Pagto. Governo & & $(500)$ & TOTAL & 14.000 \\
\hline & & Pagto. Juros & & $(500)$ & & \\
\hline & & Pagto. Funcion. & & $(500)$ & & \\
\hline & & Pagto. Dividendos & & $(500)$ & & \\
\hline & & Lucro do Período & & 3.000 & & \\
\hline & & Saldo Final & 10.000 & 4.000 & & \\
\hline
\end{tabular}

Pode-se verificar que a variação no PL é a mesma: $\$ 1.000$. Entretanto, o valor que corresponde à renda do investidor continua sendo de $\$ 1.500$, que é o quanto a empresa proporcionou de aumento na riqueza dos indivíduos que investiram na mesma, independentemente da forma como é composto o lucro líquido. Isso corresponde aos $\$ 3.000$ de lucro do período, menos os devidos ao governo, aos emprestadores, e aos funcionários ( $\$ 500 \times 3)$.

Há outras versões teóricas de lucro, além da de Valor Adicionado, conforme Hendriksen e Van Breda ${ }^{33}$ :

- Lucro Líquido da empresa: de acordo com a Associação Americana de Contadores, considera-se que não são deduções do lucro líquido as despesas de juros, o imposto de renda e os pagamentos reais de participação no lucro, ou seja, esses itens representam distribuições do lucro líquido;

- Lucro Líquido dos Investidores: o ponto de vista é o dos investidores de capital permanente: acionistas e titulares de obrigações de longo prazo.

\footnotetext{
${ }^{33}$ HENDRIKSEN, E. S. VAN BREDA, M. F. Teoria da contabilidade, p.213-6.
} 
Corresponde ao lucro antes dos juros de dívidas, dos dividendos de acionistas preferenciais e ordinários e do saldo não distribuído, mas após o imposto de renda. Essa noção de lucro possui mérito porque as decisões relativas às fontes de capital são questões financeiras, e não operacionais (operações derivadas dos ativos), além de permitir maior comparabilidade entre empresas e pelo fato de que a taxa de retorno do investimento representa melhor a eficiência relativa do capital aplicado do que a taxa de retorno para os acionistas;

- Lucro Líquido dos Acionistas: é a versão mais tradicional, em que o lucro líquido representa o retorno aos proprietários da empresa, acionistas preferenciais e ordinários. É o lucro antes das distribuições e das retenções, mas muitos consideram que esse lucro é o que pertence a todos os acionistas, uma vez que os usuários das demonstrações contábeis geralmente interpretam o lucro líquido como sendo o retorno aos acionistas;

- Lucro Líquido dos Proprietários Residuais: é o lucro líquido disponível para distribuição a acionistas ordinários, considerando que estes são os que têm direito ao residual. Nem sempre isso é verdade, pois acionistas preferenciais ou titulares de obrigações podem também assumir esses direitos. O lucro líquido residual indica o grau de segurança dos direitos prioritários, bem como o montante disponível para distribuição aos investidores residuais. 
Uma outra versão de lucro é aquela que considera como lucro apenas o que sobra após a dedução do custo de capital próprio, como coloca Assaf ${ }^{34}$ :

"Mesmo apurando lucro contábil em determinado período, porém sendo esse resultado insuficiente para remunerar 0 custo do capital investido, a empresa irá promover uma destruição da riqueza de seus proprietários, depreciando seu valor de mercado. Em verdade, o genuíno conceito de lucro voltado ao sucesso empresarial é mensurado somente após ser deduzido o custo de oportunidade do capital aplicado' ${ }^{135}$.

A isso se liga o conceito de Valor Econômico Adicionado (VEA), que é uma medida de criação de valor baseada no desempenho operacional da empresa e calculado a partir das demonstrações contábeis, como mostra Assaf:

"O VEA pode ser entendido como o resultado apurado pela sociedade que excede à remuneração mínima exigida pelos proprietários de capital (credores e acionistas). É um indicador sobre se a empresa está criando ou destruindo valor por meio de um resultado definido como supranormal por David Ricardo no início do século retrasado (1820). A partir de então, a medida foi sendo adotada por um número cada vez maior de empresas e recebendo diferentes denominações. Sua popularização maior deu-se com a denominação de Economic Value $\operatorname{Added}^{36}$ (EVA)".

Desse modo, o VEA é uma medida de desempenho da empresa, enquanto investimento de seus proprietários, uma vez que revela se o retorno está acima daquilo que obteria em outra alternativa de risco equivalente, que é o que significa a dedução do custo de capital próprio. Entretanto, o VEA não representa a renda do investidor, pois ela é o aumento da riqueza do mesmo

\footnotetext{
${ }^{34}$ ASSAF Neto, Alexandre. Finanças corporativas e valor, p. 174.

${ }^{35}$ ASSAF Neto, Alexandre. Finanças corporativas e valor, p. 166.

${ }^{36}$ Marca registrada de propriedade da Stern \& Stewart.
} 
considerado como um todo, e não apenas aquilo que ultrapassa seu custo de oportunidade. A renda pode ser superior ou inferior a isso, mas o seu valor total é o que pode ser consumido pelo indivíduo investidor. O VEA apenas sinaliza se o investimento realizado compensou ou não no período.

Adotando-se qualquer uma dessas formas de composição do lucro líquido, a renda do investidor permanece a mesma.

A composição do lucro líquido, dessa forma, serviria apenas para evidenciação, como auxílio ao usuário das demonstrações contábeis, se não estiver de fato representando a renda do investidor. Entretanto, a não evidenciação do valor da renda pode prejudicar o investidor, que de fato é um importante usuário das demonstrações.

\subsubsection{Mensuração do LUCRO}

Não é apenas a composição que pode modificar o valor do lucro. Há também a questão de sua mensuração, uma vez que há diversas metodologias de valoração do lucro.

Para alguns teóricos, nem sempre a forma como o lucro é mensurado pode levar a uma correspondência com a renda.

Guerreiro analisa o aspecto da mensuração do lucro a partir do conceito de Hicks (considerando o lucro como renda do investidor), e faz comentários a respeito do que considera como lucro econômico (baseado no conceito econômico), contrapondo com o lucro contábil: 
"Esta forma de palavra serviria também para definir lucro contábil, na forma que o lucro contábil é a figura que liga o patrimônio líquido da empresa, como demonstrado pelo seu balanço no começo do período contábil, com seu patrimônio líquido demonstrado no seu balanço no final do período. A correspondência entre as duas idéias de incremento no patrimônio líquido é, no entanto, puramente verbal: o lucro Hicksiano demanda que, na avaliação do patrimônio líquido, nós capitalizemos os recebimentos líquidos futuros esperados, enquanto o lucro contábil requer que nós avaliemos os ativos em base a seus custos não expirados".

Desse modo, Guerreiro separa em duas as medidas de lucro: o lucro contábil, calculado conforme os princípios contábeis geralmente aceitos, e 0 lucro econômico, com o patrimônio líquido mensurado pela capitalização dos recebimentos líquidos.

Guerreiro se refere ao lucro contábil como aquele mensurado de acordo com os princípios adotados para a contabilidade voltada para fins externos, em que prevalece a objetividade e o conservadorismo.

Continuando com sua análise sobre o lucro econômico e o conceito de renda, Guerreiro coloca que:

"Continuar tão bem, economicamente falando, é interpretado como manter o capital intacto em termos do valor descontado do fluxo de recebimentos líquidos futuros. O lucro econômico é gerado, portanto, assim que exista um aumento no patrimônio líquido. Por outro lado, para mensurar o lucro como incremento do patrimônio líquido é necessária a avaliação de todos os ativos da empresa com base nos recebimentos líquidos futuros esperados. O lucro é mensurado através do crescimento do patrimônio líquido originado pela manipulação dos ativos. Sob este prisma, os ativos de qualquer natureza são 'recebiveis' esperados para fluir para a empresa período a período".

Entretanto, analisando friamente o conceito de Hicks, não é possível extrair apenas dela uma assertiva conclusiva de que a renda, e no caso da 
empresa, o lucro, depende da avaliação do patrimônio com base nos recebimentos líquidos futuros esperados. Apenas podemos dizer que é a diferença de dois patrimônios do indivíduo.

Na verdade, o que está em questão é a forma como devem ser avaliados os ativos e passivos. Independentemente do método adotado, o lucro continua sendo a diferença de dois PL's. Apenas o que muda é o montante desse lucro em cada período.

O que ocorre é que o conceito de Hicks é ao mesmo tempo amplo e rigoroso, exprimindo o verdadeiro significado de renda e permitindo que diversas definições de mensuração sejam aplicadas sem ferir o conceito. Quando o autor fala em renda como diferença de dois patrimônios do indivíduo, é necessário definir a forma de avaliação desse patrimônio. É o que também conclui Silva ${ }^{37}$ :

"Após a exposição do estudo de Hicks, em nosso modo de ver, o conceito de renda tem um caráter transcendental, isto é, se põe logicamente antes da experiência; trata-se de um conceito exato e rigoroso, ao mesmo tempo em que é vago e impreciso. Por essa razão, não conduz necessariamente a contabilidade a utilizar apenas um conjunto de regras de mensuração".

Desse modo, é necessário verificar como os ativos e passivos (qualquer que seja a entidade observada pela contabilidade) podem ser mensurados, uma vez que existem várias metodologias de avaliação.

\footnotetext{
${ }^{37}$ SILVA, Alexandre dos S. Análise das formas de reconhecimento da receita na contabilidade: um enfoque no conceito econômico de lucro, p. 151.
} 


\subsubsection{Avaliação de Ativos e Passivos}

A avaliação de ativos e passivos é a questão chave para mensuração do lucro. Começando pelo passivo, vamos tratar de sua definição e da forma como deve ser valorado.

Para Iudícibus ${ }^{38}$, a definição de passivo possui as seguintes características:

- as exigibilidades devem referir-se a transações ou eventos passados ou presentes normalmente a serem pagas em um momento futuro específico;

- pode-se reconhecer exigibilidades contingentes mesmo que os eventos caracterizem a exigibilidade legal apenas no futuro;

- pode-se provisionar indenizações por prática comercial comum, mesmo que não exigidas legalmente.

Assim, passivo é um valor conhecido ou estimado a ser pago com a transferência de ativos ou com a prestação de serviços por uma entidade em um momento futuro específico a um destinatário identificável, e cujo fato gerador desta obrigação está relacionado a transações ou eventos passados ou presentes.

Segundo Iudícibus ${ }^{39}$, para os passivos:

"o valor de balanço deveria ser determinado pelo valor presente dos montantes a serem pagos no futuro. Entretanto, no que se

\footnotetext{
${ }^{38}$ IUDÍCIBUS, Sérgio de. Teoria da contabilidade, p. 110.

${ }^{39}$ IUDÍCIBUS, Sérgio de. Teoria da contabilidade, p. 142.
} 
refere às exigibilidade a curto prazo, se o montante do desconto não for relevante, poderiam ser deixadas pelo valor nominal".

Referindo-se ao ativo, Iudícibus ${ }^{40}$ faz as seguintes considerações em relação à sua definição:

1. "o ativo deve ser considerado à luz da sua propriedade e/ou à luz de sua posse e controle; normalmente as duas condições virão juntas;

2. precisa estar incluido no ativo, em seu bojo, algum direito específico a benefícios futuros (por exemplo, a proteção à cobertura de sinistro, como direito em contraprestação ao prêmio de seguro pago pela empresa) ou, em sentido mais amplo, o elemento precisa apresentar uma potencialidade de serviços futuros (fluxos de caixa futuros) para a entidade;

3. o direito precisa ser exclusivo da entidade; por exemplo, o direito de transportar a mercadoria da entidade por uma via expressa, embora benéfico, não é ativo, pois é geral, não sendo exclusivo da entidade."

Em outras palavras, ativo é um recurso econômico sob o domínio de uma entidade, incorporado independentemente da sua forma de aquisição ou constituição, que possui capacidade de prestar serviços futuros individualmente ou conjuntamente com outros ativos, e cujo valor para a entidade corresponde ao valor presente positivo dos fluxos líquidos de caixa futuros.

\footnotetext{
${ }^{40}$ IUDÍCIBUS, Sérgio de. Teoria da contabilidade, p. 94.
} 
O grande problema da mensuração dos ativos é traduzir esses potenciais de serviços futuros em equivalentes unidades monetárias, ou seja, identificar os fluxos de caixa futuros em um horizonte indefinido. Não existe um único caminho: muitas são as formas existentes para se realizar essa tradução, por causa da dificuldade de se encontrar uma maneira de mensurar o serviço futuro de forma objetiva e ao mesmo tempo praticável.

A avaliação pelo custo histórico consegue ser, ao mesmo tempo, objetiva (verificável e comprovável) e facilmente aplicável na prática porque é obtenível com facilidade: basta verificar o seu valor no documento que comprove sua aquisição.É uma visão do passado, mas que tem como principal argumento em relação à avaliação do potencial de serviços futuros o fato de que se presume que o preço acordado entre o comprador e o vendedor do recurso utilizado pela entidade seja a melhor expressão do valor econômico do ativo, no ato da transação. Como escreve Iudícibus ${ }^{41}$ :

"Isto significa que o comprador presume que o valor descontado dos fluxos futuros de caixa gerados pelo ativo, isolada ou conjuntamente com outros ativos e organizações, insumos etc., seja superior ou, pelo menos, igual ao gasto realizado para obtê-lo. Infelizmente, reconhecer a contribuição isolada de cada ativo não é uma tarefa fácil, mas presume-se que ninguém adquire um ativo por um preço superior ao valor esperado dos benefícios a serem gerados pelo mesmo."

Segundo Iudícibus ${ }^{42}$, a avaliação pelo custo continua com força porque:

\footnotetext{
${ }^{41}$ IUDÍCIBUS, Sérgio de. Teoria da contabilidade, p. 53.

${ }^{42}$ IUDÍCIBUS, Sérgio de. Teoria da contabilidade, p. 53.
} 
"o pensamento corrente sobre princípios contábeis prefere ser conservador, no sentido de não correr riscos na avaliação, a cada momento, da potencialidade do ativo em gerar serviços futuros, o que poderia levar a erros de julgamento. 0 pensamento corrente preocupa-se apenas em resguardar 0 valor original do ativo (com amortizações respectivas), pelo menos como indicador de um valor econômico aproximado, na data da transação."

Entretanto, percebe-se que a avaliação pelo custo histórico efetivamente se consagrou ao longo do tempo por causa de sua total ligação com o caixa, como mostra Martins:

"O Balanço e a Demonstração do Resultado, se elaborado à luz do custo histórico puro e na ausência de inflação, são as distribuições lógicas e racionais ao longo do tempo do Fluxo de Caixa da Empresa, e é talvez necessário que esclareçamos isso aos consumidores do nosso produto. Precisamos mostrar que um ativo possui, além das disponibilidades e das aplicações de caixa efetuadas, direitos que estão para se transformar em caixa. Além disso, possui bens que estão representando o montante de caixa desembolsado em função de sua aquisição e que o passivo representa valores a desembolsar futuramente. Logo, o balanço inteiro, sem exceção, possui ligação com 0 fluxo de caixa. A Demonstração do Resultado possui receitas que foram ou serão pagos da mesma forma, assim, os lucros obrigatoriamente transitam pelo caixa da empresa".

Além do custo histórico, outros conceitos surgiram ao longo do tempo. Teóricos de contabilidade separam os conceitos para avaliação do ativo em valores de entrada e valores de saída.

Genericamente, os valores de entrada são os valores de troca obtidos nos segmentos de mercado em que a entidade adquire seus recursos. Eles representam o sacrifício que a empresa realizou, tem ou terá que realizar para adquirir um dado recurso. Os valores de saída são os valores de troca obtidos nos segmentos de mercado em que a entidade vende seus ativos. 
Figura 3.2 - Ativos a valores de entrada e de saída ${ }^{43}$

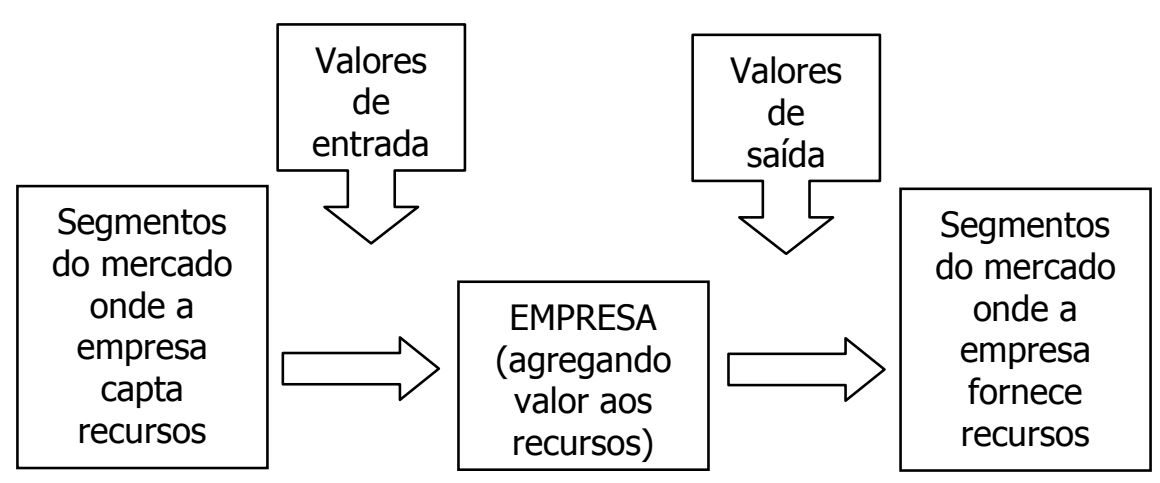

Segundo Martins ${ }^{44}$ :

"Os valores de entrada representam o sacrifício que a empresa teve (passado), tem (presente) ou terá (futuro) que realizar para adquirir um dado recurso".

Ainda de acordo com o mesmo autor, as principais opções compreendidas pelos valores de entrada são as seguintes:

- passado - custo histórico;

- presente - custo corrente;

- futuro - custo de reposição futuro.

Em relação aos valores de saída, Martins ${ }^{45}$ coloca que:

"(...) eles representam o benefício que a empresa auferiu (passado), aufere (presente) ou auferirá (futuro) com a realização de seus recursos, ou seja, com sua disponibilização no mercado".

\footnotetext{
43 MARTINS, E. Avaliação de empresas: da mensuração contábil à econômica, p. 27.

${ }^{44}$ MARTINS, E. Avaliação de empresas: da mensuração contábil à econômica, p. 28.

45 MARTINS, Eliseu (org.). Avaliação de empresas: da mensuração contábil à econômica, p. 95.
} 
Do mesmo modo, o autor ${ }^{46}$ relaciona as principais opções compreendidas pelos valores de saída, considerando as perspectivas temporais, que são as seguintes:

- Passado: valor realizado;

- Presente:

- Valor corrente de venda;

- Valor realizável líquido;

- Valor de liquidação;

- Futuro:

- Valor de realização futuro; e

- Valor presente do fluxo futuro de caixa ou valor presente líquido".

Tratando da integração das opções de avaliação, Martins ${ }^{47}$ coloca da seguinte forma:

"Repetimos: o importante aqui é mostrar que não existe uma contabilidade correta; não existe um conjunto de princípios de avaliação correto; não existe uma alternativa que, por definição, seja a única correta, o que, por conseqüência, transformaria as demais em incorretas. Existe, isso sim, uma alternativa que, para certos fins, produz informações mais ricas do que as demais. Nenhuma dessas alternativas, porém, é, por si só, capaz de atender a todas as necessidades de todos os usuários".

\footnotetext{
46 MARTINS, Eliseu (org.). Avaliação de empresas: da mensuração contábil à econômica, p. 95.

47 MARTINS, Eliseu (org.). Avaliação de empresas: da mensuração contábil à econômica, p. 337.
} 
Com essa afirmação, baseada em uma série de demonstrações que ligam os vários conceitos citados, Martins mostra que a forma de avaliação dos ativos a ser utilizada depende fundamentalmente do fim a que se destina a informação, da necessidade do usuário. Não existe uma forma mais correta que outra.

Isso significa também que não há uma forma mais correta de apuração do lucro, que é derivada da forma de avaliação dos ativos e passivos. A seguir, vamos relacionar o lucro aos fluxos de caixa, para verificar a correspondência entre ambos.

\subsection{FLUXO DE CAIXA E RENDA}

Foi visto que a chave para a valoração do lucro é a avaliação de ativos e passivos, pois é isso que determina o montante do PL e do valor do lucro nos períodos.

Foram levantadas as diversas formas de avaliação de ativos e passivos e verificou-se que elas estão baseadas principalmente em fluxos de caixa, como complementa Martins ${ }^{48}$ :

"A maior parte das mensurações contábeis, portanto, baseia-se em fluxos de caixa passados, presentes ou esperados. As receitas são geralmente medidas em termos do valor líquido de numerário que se espera receber em função da venda de bens ou da prestação de serviços. As despesas são geralmente medidas em termos do numerário pago, ou que se espera ser

\footnotetext{
${ }^{48}$ HENDRIKSEN, E. S. VAN BREDA, M. F. Teoria da contabilidade, p.174.
} 
pago por bens e serviços utilizados pela empresa. Os valores a receber ou pagar representam a alocação, ao período corrente, de recebimentos ou pagamentos futuros esperados. Os valores diferidos representam a alocação ao período corrente $e$ a períodos futuros, de recebimentos e pagamentos passados".

O lucro, nesse sentido, é a alocação racional e sistemática no tempo dos fluxos de caixa gerados. É o princípio contábil da competência dos períodos: o reconhecimento o lucro do período no momento em que ele é ganho, com receitas reconhecidas no ponto em que os produtos ou serviços são transferidos ao cliente e suas respectivas despesas confrontadas no mesmo ponto.

Para efeito de avaliação do desempenho econômico da entidade, o princípio da competência traz vantagens em relação ao reconhecimento em base caixa, pois é possível verificar se as operações realizadas no período trouxeram (ou trarão) fluxos de caixa positivos acima dos gastos necessários para obtê-los, no momento em que foram ganhos, independentemente de quando esses fluxos de caixa serão realizados.

Entretanto, isso não significa que a informação do caixa gerado no período seja absolutamente inútil. Hendriksen e Van Breda ${ }^{49}$ colocam que os fluxos de caixa assumem importância pelo fato de serem uma medida universal, independente de regras de mensuração, como ocorre com o lucro, que tem diferenças de país para país:

"Os fluxos de caixa da entidade são completamente independentes do modo pelo qual a riqueza é medida, permanecendo os mesmos em todas as formulações do lucro. Essa universalidade dos fluxos de caixa da entidade na

\footnotetext{
${ }^{49}$ HENDRIKSEN, E. S. VAN BREDA, M. F. Teoria da contabilidade, p.184.
} 
formulação de lucro ressalta, mais uma vez, a importância do fornecimento de informações sobre fluxos de caixa de uma empresa aos investidores e credores. Isso é particularmente verdadeiro na medida em que o mundo caminha para uma economia global integrada".

A idéia é a de que, mesmo que o lucro seja mensurado com base em qualquer método de avaliação de ativos, os fluxos de caixa irão ocorrer da mesma maneira. Martins ${ }^{50}$, inclusive, coloca o seguinte:

"Note que, para todas as alternativas, o fator que efetivamente valida a figura do lucro, ao longo do tempo, é o Caixa".

Nesse sentido, o lucro estará corretamente mensurado se os seus componentes passarem pelo caixa em algum momento.

Sendo assim, a geração de caixa de um período corresponde a lucros (qualquer que seja o critério de mensuração) já reconhecidos em períodos passados, no próprio período ou a serem reconhecidos em períodos futuros, o que significa que o caixa gerado também pode corresponder ao lucro.

Se o caixa gerado pode corresponder ao lucro, e com isso à renda do investidor, é possível também que esses fluxos de caixa sejam tributados. Primeiramente, iremos tratar do que deve ser expresso como renda tributável, para depois aplicar esses conceitos em termos de fluxos de caixa.

\footnotetext{
50 MARTINS, Eliseu (org.). Avaliação de empresas: da mensuração contábil à econômica, p. 340-1.
} 


\subsection{RENDA E LUCRO TRIBUTÁVEL}

\subsubsection{O QUe É ATUALMENTE O LUCRo TRIBUtável}

Como visto anteriormente, a tributação do lucro das empresas ganha forte apelo para sua existência por causa de sua viabilidade administrativa por parte do governo, em parte porque há uma legislação comercial que obriga as empresas a realizarem sua contabilidade.

Tendo uma base contábil para servir como base de cálculo para o imposto, com princípios regendo a forma de escrituração, o governo passa a reunir condições de cobrar e fiscalizar o imposto de forma mais eficiente. Assim, o lucro apurado conforme os princípios contábeis geralmente aceitos foi eleito como base de cálculo do imposto de renda e da contribuição social.

Na verdade, nem sempre o lucro apurado de acordo com os princípios contábeis é a base de cálculo do imposto de renda.

A base de cálculo do imposto de renda no Brasil é o montante real, presumido ou arbitrado, das rendas e proventos tributáveis. Em função disso, existem atualmente três modalidades de tributação para o cálculo dos tributos diretos: Lucro Real, Presumido e Arbitrado.

O Lucro Real é o lucro líquido do período apurado contabilmente ajustado pelas adições, exclusões e compensações autorizadas pela legislação. O termo "real" é utilizado em oposição aos termos presumido e arbitrado, ou 
seja, o lucro calculado a partir de receitas, custos e despesas. Esse termo não expressa o sentido de lucro verdadeiro, em função de seus ajustes arbitrários.

O lucro presumido é uma forma simplificada de apuração, na qual se presume que o lucro é um percentual da receita bruta, e sobre esse lucro é aplicada a alíquota.

O Lucro Arbitrado é utilizado pela autoridade tributária para determinação da base de cálculo dos tributos quando a pessoa jurídica não mantém escrituração na forma das leis comerciais e fiscais, mantiver escrituração com vícios, erros ou deficiências ou recusar-se a apresentar livros e documentos da escrituração comercial e fiscal à autoridade tributária.

Para a determinação do Lucro Real, é necessário fazer os ajustes na forma de adições, exclusões e compensações ao lucro contábil. Além disso, há outras regras atualmente que, na prática, podem acabar modificando o próprio lucro contábil, uma vez que a lei determina que seja feito dessa forma. É o caso do não reconhecimento dos resultados com a inflação e a possibilidade de dedução dos juros sobre capital próprio.

Devido à sua sistemática de composição da base de cálculo, não se pode dizer que a tributação atual do imposto de renda é exatamente sobre a renda. Teoricamente, quando o governo quer tributar a renda na empresa, seu objetivo é tributar o lucro que é de direito dos proprietários, ou seja, a renda obtida pelos detentores do capital da empresa. Aliás, como visto anteriormente, não há renda da empresa, mas sim renda gerada pela empresa, o que significa 
que a tributação sobre a renda na empresa, na verdade, ocorre sobre a renda do investidor.

O imposto não é sobre a renda do investidor porque a base não é o valor destinado aos proprietários, e sim uma composição de lucro com elementos que são favorecedores ao fisco com uma forma de mensuração que está próxima do custo histórico, mas tem elementos em base caixa, como é o caso de determinadas despesas que são indedutíveis quando reconhecidas contabilmente, mas dedutíveis na realização financeira.

Assim, é necessário entender como deveria funcionar um imposto efetivamente incidente sobre a renda dos proprietários.

\subsubsection{O que Deveria Ser Renda Tributável?}

Se é o indivíduo que obtém a renda, esta poderia ser tributada diretamente sobre a pessoa física, inclusive com o somatório de todos os seus rendimentos, uma vez que o indivíduo pode ter outras fontes de renda, como salário, além da renda provinda da empresa em que investe. Teoricamente, isso poderia inclusive ocorrer em base competência, e não em base caixa, como ocorre hoje - a tributação da pessoa física ocorre no recebimento da renda.

A tributação da renda do indivíduo na empresa implica em algumas diferenças. Teríamos que ter a tributação de todo tipo de renda destinada aos indivíduos: salários, aluguéis, juros e lucros. A tributação da renda na empresa 
seria apenas uma forma de realizar retenção na fonte, para simplificação e agilização do processo de cobrança.

A questão mais complicada seria a tributação da renda referente ao lucro, porque a determinação do valor dos demais tipos de renda é mais direta e normalmente realizada via contratos com valores previamente estabelecidos. A tributação da renda dos proprietários só poderia ocorrer sobre aquilo que efetivamente representa aumento no capital investido. Para ser purista, isso significa que o fisco não poderia compor bases de cálculo que the fossem convenientes, deixando, por exemplo, de admitir determinados resultados que não Ihe fossem interessantes, mesmo que politicamente, como é o caso atual da extinção da correção monetária. Além disso, não poderia haver, para efeito de tributação, resultados não-operacionais que não fossem tributáveis ou indedutíveis.

A participação de uma empresa no capital de outra cria uma dificuldade, uma vez que o lucro da investida não necessariamente pode representar renda para o indivíduo que é proprietário da investidora, e assim não poderia ser tributada na primeira. A maneira de se contornar isso, que tem sido utilizada na prática, é tributar na primeira e excluir da base de cálculo do imposto da investidora.

O importante é que não haja bitributação. Se a renda já foi tributada na empresa, o seu beneficiário não pode ser tributado novamente, seja ele o indivíduo que investiu nela, seja uma outra empresa. 


\subsubsection{O que Deveria Ser LuCro Tributável?}

A tributação do lucro não necessariamente é correspondente à tributação da renda, porque renda, apesar de determinados problemas de mensuração, só tem uma definição: é aquilo que representa aumento no valor investido pelo proprietário. O lucro, por sua vez, pode ser medido e composto segundo enfoques diferentes, como visto anteriormente.

O governo, como alternativa à tributação da renda, poderia escolher um método de mensuração e uma composição de lucro que esteja de acordo com a sua política tributária. Qualquer composição que não corresponda à renda, pode trazer efeitos diferentes.

Em relação à mensuração do lucro, a questão a ser tratada é a da avaliação do ativo. O método de avaliação do ativo não interfere no total de tributos devidos pela entidade, considerando toda a vida da empresa e desconsiderando o valor do dinheiro no tempo. Entretanto, deve interferir nos valores temporais, uma vez que a avaliação por uma ou outra forma altera o momento de reconhecimento de resultados. Por exemplo: suponhamos que a empresa tenha um estoque cujo preço de mercado aumentou e que seu ativo esteja sendo avaliado pelo método do custo histórico. Esses ganhos somente serão reconhecidos no momento da venda. Se o método de avaliação fosse o de custo corrente, esse ganho deveria ser reconhecido no momento em que a mercadoria aumentou de preço, mesmo que não tenha sido vendido, que pode ser diferente do momento de reconhecimento pelo método do custo histórico. 
Entretanto, qualquer que seja o momento de reconhecimento de receitas e despesas, o gasto com impostos será o mesmo, desconsiderando o custo do dinheiro no tempo, uma vez que a diferença será apenas temporal. O problema do valor do dinheiro no tempo será analisado com maior profundidade no próximo capítulo.

A proibição atual do reconhecimento dos resultados inflacionários representa uma mudança na forma de avaliação dos ativos, passando de custo histórico corrigido ${ }^{51}$ para simplesmente custo histórico. A intenção do governo, à época da edição do Plano Real, era claramente a de evitar a retomada de tendência de reindexação e de promover a perda da "memória inflacionária" nas empresas. $O$ efeito perverso dessa política é o risco de as empresas se descapitalizarem em função de distribuições maiores de lucro do que o devido.

Em relação à composição do lucro tributável, isso depende da visão do fisco em relação ao que é importante considerar em sua base de cálculo, uma vez que isso pode incentivar ou não determinadas atividades ou relações das empresas.

Os incentivos fiscais também são uma forma de alteração na composição do lucro que favorece as atividades sociais que o governo deseja promover ou

\footnotetext{
${ }^{51} \mathrm{Na}$ verdade, o método de correção monetária adotado pela lei 6.404/76, anterior à lei atual, leva a uma aproximação do ativo avaliado a custo histórico corrigido, embora reconheça o mesmo resultado inflacionário obtido pelo método de correção monetária integral, que efetivamente corresponde ao custo histórico corrigido.
} 
incentiva o desenvolvimento de determinadas regiões geográficas menos favorecidas.

Há também outros itens do resultado que merecem atenção. A depreciação é um deles, pois deve compor o resultado do período por representar a distribuição do consumo dos ativos de longa duração nos vários períodos, fazendo com que o resultado líquido seja o retorno obtido acima do consumo dos investimentos. Essa colocação assume importância quando tratarmos dos fluxos de caixa de investimento.

Há um item do resultado de grande relevância para efeito de tributação, que é o da despesa financeira, uma vez que há implicações sobre a definição da estrutura de capital das empresas. A respeito disso, serão discutidas as teorias que envolvem essa questão.

\subsubsection{A Teoria de Modigliani e Miller sobre Estrutura de Capital}

Modigliani e Miller $^{52}$ (MM) afirmam que o custo geral de capital da empresa, sem considerar os impostos, não pode ser reduzido com a substituição de capital próprio por capital de terceiros.

\footnotetext{
52 MODIGLIANI, Franco, MILLER, Merton $\mathrm{H}$. The cost of capital, corporation finance and the theory of investiment e MODIGLIANI, Franco, MILLER, Merton H. Corporate income taxes and cost of capital: a correction.
} 
Essa é a chamada Proposição I de MM. Eles comparam duas empresas, uma apenas com capital próprio (A) e outra com uma parte de capital de terceiros (B), sob o ponto de vista de um investidor.

Se este investir em $10 \%$ das ações de $A$, estará adquirindo também $10 \%$ do valor de $A$, esperando receber $10 \%$ dos lucros.

Entretanto, se ele investir em $10 \%$ das ações de B, o investimento será menor, assim como sua participação nos lucros, em função dos juros sobre capital de terceiros.

O investidor resolve então tomar emprestado o correspondente a $10 \%$ da dívida de $B$, à mesma taxa, e em seguida utilizar o dinheiro captado mais recursos próprios para comprar $10 \%$ das ações de A. Os recursos próprios necessários para esse investimento são menores do que se não tivesse tomado o empréstimo, assim como será menor o lucro, porque agora deve pagar juros.

Os lucros do investidor, tanto adquirindo $10 \%$ das ações de B ( $1^{\circ}$ caso), como fazendo o empréstimo e adquirindo $10 \%$ das ações de $A\left(2^{\circ}\right.$ caso), serão iguais. A diferença é que no segundo ele irá receber dividendos de A, mas terá que pagar os juros do seu empréstimo, ficando com o mesmo valor em dinheiro nos dois casos.

No primeiro caso, o investimento corresponde a $10 \%$ do PL (da diferença entre o valor da empresa B e seus passivos). No segundo caso, o investimento corresponde a $10 \%$ do valor da empresa A menos a dívida contraída pelo investidor, que corresponde a $10 \%$ dos passivos de B. Assim:

10 Caso: $0,10 \times$ (Valor de $B-$ Passivos de B)

$2^{\circ}$ Caso: $0,10 \times$ Valor de $A-0,10 \times$ passivos de $B$; ou 
$0,10 \times$ (Valor de A - Passivos de B)

Sendo os lucros iguais em ambos os casos, os retornos somente serão iguais se os investimentos também forem. Para isso, Valor de A e Valor de B nas expressões acima devem ser iguais. Assim, chegamos à Proposição I de MM: o valor da empresa sem capital de terceiros é igual ao da empresa com capital de terceiros.

À medida que a empresa acrescenta mais capital de terceiros, o capital próprio remanescente se torna mais arriscado. À medida que esse risco se eleva, o custo de capital próprio acaba aumentando. O aumento do custo do capital próprio remanescente compensa a vantagem obtida com a maior proporção da empresa financiada com capital de terceiros mais barato. MM provam que os dois efeitos compensam um ao outro exatamente, de modo que o valor da empresa e o custo geral de capital acabam sendo insensíveis ao grau de endividamento.

Essa é a chamada Proposição II de MM. Partindo da formulação do custo médio ponderado de capital e da Proposição I, MM chegam à conclusão de que o retorno exigido do capital próprio é uma função linear do quociente entre capital de terceiros e capital próprio.

A fórmula do custo médio ponderado de capital é:

$$
r_{W A C C}=\frac{B}{B+S} \cdot r_{B}+\frac{S}{B+S} \cdot r_{S}
$$

Onde:

$\mathrm{r}_{\mathrm{B}}=$ taxa de juros (custo de capital de terceiros)

$r_{\mathrm{S}}=$ retorno esperado do capital próprio

$r_{\text {WACC }}=$ custo médio ponderado de capital 
$B=$ valor das dívidas

$\mathrm{S}=$ valor das ações, ou do capital próprio

Conforme a Proposição I de MM, $r_{\text {wACC }}=r_{0}$, sendo $r_{0}=$ custo de capital de uma empresa sem capital de terceiros, ou seja, sem risco financeiro. Assim, igualando a equação do r rwacc, temos:

$$
\frac{B}{B+S} \cdot r_{B}+\frac{S}{B+S} \cdot r_{S}=r_{0}
$$

Reescrevendo a equação, obtém-se:

$$
r_{S}=r_{0}+\frac{B}{S} \cdot r_{0}\left(r_{0}-r_{B}\right)
$$

Desta equação, depreende-se que se $r_{0}$ for superior à taxa de juros $r_{B}$, então o custo de capital próprio crescerá na mesma proporção do quociente capital de terceiros/capital próprio. Isso significa também que à medida que a empresa eleva o quociente capital de terceiros/capital próprio, cada unidade monetária de capital próprio é alavancada com capital de terceiros adicional. Isto eleva o risco do capital próprio e, portanto, o retorno exigido sobre o capital próprio, $\mathrm{r}_{\mathrm{S}}$.

Essas proposições de MM são feitas sem se considerar o efeito dos impostos. Nos Estados Unidos, em cuja estrutura fiscal foi baseado o estudo, como no Brasil, as despesas financeiras são dedutíveis do imposto de renda. Isso provoca um efeito diferente sobre as conclusões obtidas nas duas proposições de MM. Como os juros são dedutíveis, há uma vantagem fiscal na utilização de capital de terceiros.

Para uma empresa sem dívidas, o lucro depois do imposto de renda é: 


$$
=\operatorname{LAJI} x(1-T c)
$$

Onde:

LAJI = Lucro antes dos juros e dos impostos

$\mathrm{T}_{\mathrm{C}}=$ Alíquota do imposto de renda

Para uma empresa com dívidas, o lucro líquido para os acionistas é dado por:

$$
\begin{aligned}
& L A J I-r_{B} B-T c x\left(L A J I-r_{B} B\right)= \\
= & \left(L A J I-r_{B} B\right) x(1-T c)
\end{aligned}
$$

onde:

$r_{B}=$ taxa de juros sobre capital de terceiros

$B=$ Capital de terceiros

Somando-se a isso os juros pagos aos credores, obtemos:

$$
\operatorname{LAJI} x(1-T c)+T c r_{B} B
$$

A diferença de (2) para (1), $T_{C} r_{B} B$, é o fluxo de caixa adicional aos investidores na empresa com dívidas, tanto acionistas como credores, também chamado de benefício fiscal do uso de capital de terceiros.

O valor de uma empresa sem dívidas é o valor presente do lucro depois do imposto de renda, expresso na fórmula (1), descontado do custo de capital de uma empresa sem dívidas, como segue:

$$
V_{A}=\frac{L A J I \cdot\left(1-T_{C}\right)}{r_{0}}
$$

Onde:

$\mathrm{V}_{\mathrm{A}}=$ valor presente de uma empresa sem dívidas

$r_{0}=$ custo de capital de uma empresa sem dívidas 
Para se chegar ao valor da empresa com dívidas, é necessário calcular também o valor presente do benefício fiscal, descontando pela taxa de juros sobre o capital de terceiros. Assim, temos:

$$
\begin{gathered}
V_{B}=\frac{L A J I .\left(1-T_{C}\right)}{r_{0}}+\frac{T_{C} r_{B} B}{r_{B}} \\
=V_{A}+T_{C} B
\end{gathered}
$$

Portanto, de acordo com a expressão, quando existe imposto de renda, o valor da empresa é uma função crescente do grau de endividamento.

A Proposição II, com impostos, ficaria do seguinte modo:

$$
r_{S}=r_{0}+\frac{B}{S} .\left(1-T_{C}\right) x\left(r_{0}-r_{B}\right)
$$

As Proposições de MM com impostos indicam que as empresas devem ter estruturas de capital compostas quase inteiramente por capital de terceiros.

Porém, há outros fatores que influenciam na determinação da estrutura de capital.

Um dos fatores que contribui para a determinação da estrutura de capital é a taxa de imposto de renda incidente sobre os dividendos e os juros recebidos pelos emprestadores.

As proposições de MM levavam em conta apenas o imposto de renda incidente sobre os juros sobre capital de terceiros, cujos resultados levariam à conclusão de que as empresas mais alavancadas teriam maior valor.

Porém, Miller apresenta um outro modelo incluindo os impostos incidentes sobre os dividendos e os juros recebidos pelas pessoas físicas.

O valor que os acionistas recebem corresponde a: 


$$
\left(L A J I-r_{B} B\right) x(1-T c) x\left(1-T_{S}\right)
$$

Os credores recebem:

$$
r_{B} B x\left(1-T_{B}\right)
$$

Onde:

$\mathrm{T}_{\mathrm{C}}=$ Alíquota do imposto de renda de pessoa jurídica

$\mathrm{T}_{\mathrm{S}}=$ Alíquota do imposto de renda de pessoa física sobre dividendos

$\mathrm{T}_{\mathrm{B}}=$ Alíquota do imposto de renda de pessoa física sobre juros recebidos

O fluxo total de caixa para os acionistas e credores, somando as duas equações, pode ser escrito da seguinte forma:

$$
\operatorname{LAJIx}(1-T c) x\left(1-T_{S}\right)+r_{B} B x\left(1-T_{B}\right) x\left[1-\frac{(1-T c) x\left(1-T_{S}\right)}{\left(1-T_{B}\right)}\right]
$$

Substituindo o primeiro termo da equação por $V_{A}$, que é o valor de uma empresa sem dívidas, e a primeira parte do segundo termo por $B$, que é o quanto o credor irá receber, temos:

$$
V_{B}=V_{A}+\left[1-\frac{(1-T c) x\left(1-T_{S}\right)}{\left(1-T_{B}\right)}\right] x B
$$

Se a taxa de imposto sobre os juros recebidos pelos credores $\left(T_{B}\right)$ for igual à taxa sobre os dividendos $\left(T_{s}\right)$, essa equação transformar-se-ia em:

$$
V_{B}=V_{A}+T_{C} B
$$

Ou seja, o mesmo resultado sem a consideração do imposto de renda pessoa física.

Se $\left(1-T_{B}\right)>\left(1-T_{C}\right) \times\left(1-T_{S}\right)$, mas com $T_{B}>T_{S}$, o ganho com 0 endividamento será menor que no resultado acima, reduzindo assim a vantagem do uso de capital de terceiros. Porém, se $\left(1-T_{B}\right)>\left(1-T_{C}\right) \times\left(1-T_{S}\right)$, 
mas com $T_{B}<T_{S}$, o ganho com o endividamento será maior que no resultado acima.

Essa vantagem somente será nula se:

$$
(1-T c) x\left(1-T_{S}\right)=\left(1-T_{B}\right)
$$

O valor da empresa com dívidas só será menor se $\left(1-\mathrm{T}_{\mathrm{B}}\right)<\left(1-\mathrm{T}_{\mathrm{C}}\right) \times(1-$ $\left.\mathrm{T}_{\mathrm{S}}\right)$.

Assim, o endividamento poderia aumentar o valor da empresa. Se considerarmos a realidade brasileira, com taxação zero para a distribuição de dividendos e uma alíquota aproximada de $34 \%$ sobre a pessoa jurídica, o endividamento teria efeito benéfico para a empresa, aumentando seu valor.

Isso, porém, se aplica quando se pressupõe que o imposto é constante sobre a renda da pessoa física, ou que todos os indivíduos estão sujeitos à mesma alíquota de imposto de renda sob a forma de juros.

Miller considerou as implicações do imposto de renda da pessoa física quando as alíquotas diferem de uma pessoa para outra, nos casos em que é progressivo, por exemplo, ou quando entidades são isentas de imposto.

Para isso, Miller partiu do raciocínio de igualdade de taxas: a que taxa de juros a empresa ficaria indiferente entre obter capital de terceiros e emitir novas ações?

A empresa ficaria indiferente quando o custo do capital de terceiros, após o imposto de renda, seja igual ao custo do capital próprio:

$$
(1-T c), r_{B}=r_{S}
$$

Onde:

$\mathrm{T}_{\mathrm{c}}=$ Alíquota do imposto de renda 
$r_{\mathrm{B}}=$ taxa de juros sobre capital de terceiros

$r_{S}=$ retorno esperado do capital próprio

Supondo que $T_{c}$ seja igual a $34 \%$ e $r_{S}$ igual a $10 \%$, a empresa poderia pagar até $15,15 \%$ de juros.

Segundo Miller, os contribuintes situados nas faixas de renda com menor percentual de imposto irão comprar os títulos de dívida por pagar menos imposto.

Damodaran ${ }^{53}$ explica da seguinte forma:

"Segundo o modelo Miller, as empresas captarão recursos de terceiros em volume suficiente para atrair indivíduos situados em todas as faixas de imposto até 34\%, inclusive. Para induzir esses investidores a comprar as obrigações, a taxa de juros competitiva será igual a 15,15\%. Nenhuma empresa ganhará com a emissão de títulos de dívida, em equilíbrio. Em vez disso, todas as empresas ficarão indiferentes entre emitir obrigações $e$ lançar novas ações quando se estiver no ponto de equilibrio".

11. Em termos agregados, as empresas emitirão títulos de dívida em quantidade suficiente para serem adquiridos pelos indivíduos situados em faixas de imposto com alíquota abaixo ou igual à alíquota de imposto de pessoa jurídica, $T_{a}$ ao passo que os indivíduos situados em faixas superiores não comprarão obrigações. Portanto, esses indivíduos aplicarão seu dinheiro em ações."

"2. Como as pessoas situadas em faixas de imposto com alíquota igual à da pessoa jurídica aplicarão em obrigações, não haverá ganho ou perda com o uso de capital de terceiros pela empresa. Portanto, a decisão de estrutura de capital será irrelevante para uma empresa específica qualquer. Embora o modelo Miller seja bastante sofisticado, esta conclusão é

${ }^{53}$ DAMODARAN, Aswath. Finanças corporativas aplicadas, p.257. 
idêntica à obtida por MM numa situação em que se supunha não haver impostos."

Damodaran ${ }^{54}$ faz considerações adicionais sobre a relevância do modelo de Miller:

"A análise de Miller introduziu pela primeira vez as alíquotas de imposto de renda de investidores, proporcionando alguma reflexão a respeito do papel das preferências do investidor em relação ao imposto de renda sobre a estrutura de capital de uma empresa. Como reparou o próprio Miller, no entanto, essa análise não restabelece a irrelevância da dívida sob todas as circunstâncias; em vez disso, ela abre a possibilidade de que a dívida ainda possa ser irrelevante, apesar de suas vantagens tributárias' 155 .

Apesar de verificadas as conseqüências sobre a estrutura de capital da empresa, é preciso considerar que, se as despesas financeiras deixassem de ser dedutíveis do IR, estaríamos beneficiando empresas que tem reduzido acesso a capital de terceiros, mas por outro lado estaríamos prejudicando as empresas mais alavancadas, inclusive podendo reduzir o seu valor de mercado.

Um outro ponto é o de há indícios de que o imposto de renda não é fator preponderante na decisão de estrutura de capital, como mostra Damodaran ${ }^{56}$ :

"Pesquisas com administradores financeiros indicam que, ao contrário do que ocorre em nossa teoria, eles levam muito em consideração a análise de opções mencionada anteriormente. Em uma pesquisa feita por Pinegar e Wilbricht (1989), foi solicitado a administradores que citassem os dados mais

\footnotetext{
${ }^{54}$ DAMODARAN, Aswath. Finanças corporativas aplicadas, p.257-8.

${ }^{55}$ DAMODARAN, Aswath. Finanças corporativas aplicadas, p.257-8.

${ }^{56}$ DAMODARAN, Aswath. Finanças corporativas aplicadas, p.257-8.
} 
importantes que orientam suas decisões sobre financiamento. Suas respostas estão classificadas segundo a ordem de importância dada a elas na tabela 7.3.".

Tabela 3.5- Dados Integrantes das Decisões sobre Estrutura de Capital ${ }^{57}$

\begin{tabular}{|c|c|c|c|c|c|c|c|}
\hline \multicolumn{8}{|c|}{ Tabela 7.3 Dados Integrantes das Decisões sobre Estrutura de Capital } \\
\hline \multirow{3}{*}{$\begin{array}{l}\text { Dados/Pressupostos por } \\
\text { Ordem de importância }\end{array}$} & \multicolumn{7}{|c|}{ Percentagem de respostas em cada classificação } \\
\hline & \multicolumn{5}{|c|}{ Menos importante ...Mais importante } & \multirow[b]{2}{*}{ Não classif. } & \multirow[b]{2}{*}{ Média } \\
\hline & 1 & 2 & 3 & 4 & 5 & & \\
\hline $\begin{array}{l}\text { 1. Fluxo de caixa projetado do } \\
\text { ativo a ser financiado }\end{array}$ & $1,7 \%$ & $1,1 \%$ & $9,7 \%$ & $29,5 \%$ & $58,0 \%$ & $0,0 \%$ & 4,41 \\
\hline $\begin{array}{l}\text { 2. Evitando a diluição de } \\
\text { direitos do capital social }\end{array}$ & $2,8 \%$ & $6,3 \%$ & $18,2 \%$ & $39,8 \%$ & $33,0 \%$ & $0,0 \%$ & 3,94 \\
\hline $\begin{array}{l}\text { 3. Risco do ativo a ser } \\
\text { financiado }\end{array}$ & $2,8 \%$ & $6,3 \%$ & $20,5 \%$ & $36,9 \%$ & $33,0 \%$ & $0,6 \%$ & 3,91 \\
\hline $\begin{array}{l}\text { 4. Cláusulas restritivas sobre } \\
\text { títulos preferenciais }\end{array}$ & $9,1 \%$ & $9,7 \%$ & $18,7 \%$ & $35,2 \%$ & $27,3 \%$ & $0,0 \%$ & 3,62 \\
\hline $\begin{array}{l}\text { 5. Evitando estabelecer um } \\
\text { preço errado de títulos a serem }\end{array}$ & & & & & & & \\
\hline emitidos & $3,4 \%$ & $10,8 \%$ & $27,3 \%$ & $39,8 \%$ & $18,7 \%$ & $0,0 \%$ & 3,60 \\
\hline $\begin{array}{l}\text { 6. Alíquota de imposto de } \\
\text { renda sobre empresas }\end{array}$ & $4,0 \%$ & $9,7 \%$ & $29,5 \%$ & $42,6 \%$ & $13,1 \%$ & $1,1 \%$ & 3,52 \\
\hline 7. Controle de voto & $17,6 \%$ & $10,8 \%$ & $21,0 \%$ & $31,2 \%$ & $19,3 \%$ & $0,0 \%$ & 3,24 \\
\hline $\begin{array}{l}\text { 8. Depreciação e outras elisões } \\
\text { de impostos }\end{array}$ & $8,5 \%$ & $17,6 \%$ & $40,9 \%$ & $24,4 \%$ & $7,4 \%$ & $1,1 \%$ & 3,05 \\
\hline $\begin{array}{l}\text { 9. Corrigindo erros no preço de } \\
\text { títulos }\end{array}$ & $27,8 \%$ & $36,4 \%$ & $14,2 \%$ & $5,1 \%$ & $1,7 \%$ & $0,0 \%$ & 2,66 \\
\hline $\begin{array}{l}\text { 10. Alíquotas de imposto de } \\
\text { renda sobre a pessoa física e } \\
\text { portadores de dívida e ações }\end{array}$ & $31,2 \%$ & $\begin{array}{l}34,1 \% \\
13,1 \%\end{array}$ & $25,6 \%$ & $\begin{array}{l}8,0 \% \\
40 \%\end{array}$ & $\begin{array}{l}1,1 \% \\
45 \%\end{array}$ & $\begin{array}{l}0,0 \% \\
23 \%\end{array}$ & $\begin{array}{l}2,14 \\
1,58\end{array}$ \\
\hline 11. Custos de falência & $69,3 \%$ & $13,1 \%$ & $6,8 \%$ & $4,0 \%$ & $4,5 \%$ & $2,3 \%$ & 1,58 \\
\hline
\end{tabular}

No Brasil, não foi encontrada pesquisa semelhante, mas é possível que o imposto de renda até tenha uma importância maior nessa decisão, em função da alta carga e do menor número de companhias abertas no mercado, embora tenda a não ser também o fator preponderante.

${ }^{57}$ Adaptado de: DAMODARAN, Aswath. Finanças corporativas aplicadas, p.257-8. 


\subsubsection{Consideraçõ̃es a ResPeito do LuCRo TRIBUtável}

Como visto, o método de mensuração do lucro e a sua estrutura de composição são objetos de política tributária do governo. A adoção de uma base de cálculo do imposto revela quais são os aspectos que o governo está levando em conta em termos de incentivo econômico e social, uma vez que a inclusão ou não de determinado item de resultado na base de cálculo pode trazer efeitos à economia como um todo.

Se o governo resolvesse, por exemplo, tornar indedutível a despesa financeira, o uso de capital de terceiros teria um atrativo menor, podendo com isso reduzir a circulação monetária e os seus efeitos.

Em uma outra hipótese, se o governo resolvesse tornar o custo do capital próprio e de terceiros dedutíveis, o efeito seria diferente. Adaptando a equação de Miller, a empresa ficaria indiferente à captação de recursos próprios ou de terceiros quando:

$$
\begin{aligned}
(1-T c) \cdot r_{B} & =(1-T c) \cdot r_{S} \\
r_{B} & =r_{S}
\end{aligned}
$$

Já o valor da empresa seria expresso da seguinte forma:

$$
\begin{aligned}
& V_{B}=\frac{L A J I \cdot\left(1-T_{C}\right)}{r_{0}}+\frac{T_{C} r_{B} B}{r_{B}}+\frac{T_{C} r_{S} S}{r_{S}} \\
& V_{B}=\frac{L A J I \cdot\left(1-T_{C}\right)}{r_{0}}+T c B+T C S
\end{aligned}
$$


Assim, se o custo de capital próprio e de terceiros fossem dedutíveis, teríamos dois efeitos interessantes:

- a empresa ficaria indiferente à captação de recursos próprios ou de terceiros se a taxa de ambos fossem iguais, e

- o valor da empresa seria uma função crescente da taxa de imposto de renda, uma vez que B e S são complementares.

Esses são apenas alguns exemplos de como a composição do lucro tributável pode trazer efeitos diversos e podem ser mecanismos de política tributária.

Dada a diversidade de efeitos que podem ser causados por mudanças na forma de mensuração e na composição do lucro, vamos basear o estudo adiante do modelo de tributação por fluxos de caixa no conceito de renda, em função deste não possuir diferentes composições que possam fazer multiplicar as abordagens. Além disso, vamos considerar que a renda é medida a partir dos ativos avaliados a custo histórico corrigido.

A seguir, será discutida a possibilidade de a tributação ser efetuada não sobre o lucro, mas sobre o fluxo de caixa. Isso não representa uma alteração na forma de mensuração do lucro tributável e nem na sua composição; é uma alteração na distribuição temporal do que é tributável, mas que traz outros efeitos em termos de política tributária. 


\subsection{TRIBUTAÇÃO SOBRE O FLUXO DE CAIXA}

\subsubsection{Composição dos FluXos de CAIXA}

Os fluxos de caixa realizados poderiam ser demonstrados de várias maneiras, inclusive sem qualquer forma de agrupá-los. Entretanto, a separação dos itens em grupos pode ajudar o leitor (ou mesmo o fisco) em sua análise.

Hendriksen e Van Breda ${ }^{58}$ fazem um levantamento dos principais grupamentos de fluxos de caixa, de acordo com o objetivo da contabilidade:

"Os investidores e credores, portanto, tenderão a ser ajudados na predição dos níveis futuros de dividendos se dispuserem de informação concernente aos seguintes tipos de fluxos:

1. Fluxos de caixa relacionados às operações básicas correntes da empresa.

2. Fluxos de caixa regulares ou eventuais, não relacionados às operações correntes, mas resultantes de eventos inesperados ou do desejo de manter um bom ambiente operacional para a empresa no futuro.

3. Fluxos de caixa necessários para ampliar as instalações operacionais e os estoques, ou obtidos com sua venda quando não são mais necessários para as operações futuras.

4. Caixa obtido de credores e acionistas, ou pago a eles, como parte do financiamento da empresa.

${ }^{58}$ HENDRIKSEN, E. S. VAN BREDA, M. F. Teoria da contabilidade, p.178. 
5. Pagamentos de juros e dividendos a investidores com direitos prioritários, tais como acionistas preferenciais".

O Fasb (Financial Accounting Standards Board) norte-americano, em sua norma contábil FAS-95, explicita os critérios para a classificação dos fluxos de caixa e recomenda dois métodos de apresentação, o Direto e o Indireto. O Iasb (International Accounting Standards Board) tem também uma norma bastante semelhante. De um modo geral, os fluxos são separados em três atividades: operacionais, de investimento e de financiamento. A diferença entre os dois métodos de apresentação está apenas nas atividades operacionais - o método Direto apresenta os fluxos por recebimentos e pagamentos e o Indireto apresenta uma conciliação entre o lucro líquido contábil e o caixa líquido gerado pelas atividades operacionais.

Os critérios de classificação são os seguintes:

- Atividades Operacionais

- Entradas de caixa referentes a:

- venda de mercadorias ou serviços;

- valores obtidos sobre empréstimos feitos a terceiros (juros) e sobre investimentos em ações (dividendos), incluindo os dividendos recebidos daqueles investimentos avaliados pelo método de equivalência patrimonial;

- todas e quaisquer transações não definidas como atividades de investimento ou financiamento, incluindo valores recebidos das decisões judiciais ou legais, valores referentes a seguros não 
pertinentes diretamente às atividades de investimento ou financiamento e devolução de pagamentos ou adiantamentos feitos a fornecedores, por exemplo.

- Saídas de caixa referentes a:

- Aquisição de materiais para produção ou para revenda;

- Salários e encargos sociais dos empregados;

- Juros sobre empréstimos;

- Impostos, multas e outras despesas legais;

- Materiais e serviços gerais;

- Todas e quaisquer transações não definidas como atividade de investimento ou financiamento, incluindo pagamentos relativos a causas judiciais, donativos e devolução de pagamentos a clientes, por exemplo.

- Atividades de Investimento:

- Saídas de caixa para:

- Aquisição de ativos imobilizados (inclusive juros e despesas capitalizadas);

- Aquisição de novos negócios e empresas;

- Aquisição de debêntures e investimentos financeiros a longo prazo;

- Aquisição de ações de outras empresas, inclusive investimentos regulados pelos métodos de equivalência patrimonial; 
- Empréstimos feitos a outras entidades;

- Compra por transferência de debêntures de outras entidades;

- Entradas de caixa de:

- Venda de ativos imobilizados;

- Venda de uma unidade de negócios como uma subsidiária ou divisão;

- Cobrança do principal relativo a empréstimos feitos a outras entidades;

- Venda, por transferência, de debêntures de outras entidades;

- Venda de debêntures ou ações de outras entidades (não inclui aplicações de caixa).

- Atividades de Financiamento:

- Saídas de caixa para:

- Remuneração aos proprietários na forma de dividendos ou outras distribuições;

- Pagamento de valores tomados por empréstimos, inclusive empréstimos de curto e longo prazo, obrigações de leasing de capital e resgate de debêntures;

- Reaquisição de ações próprias e outros títulos de emissão própria relativos ao patrimônio líquido;

- Recebimentos por:

- Emissão de ações; 
- Subscrição de debêntures, hipotecas e empréstimos de curto e longo prazo.

Percebe-se que a intenção dessa classificação é separar os fluxos entre os que são derivados das operações, com forte correspondência com os itens da $\mathrm{DRE}$, os decorrentes dos investimentos e os que estão relacionados a entradas e saídas de capital, próprio ou de terceiros. O que mostra a correspondência do fluxo de caixa operacional com a DRE é a inclusão de itens que poderiam estar classificados nos outros grupos, como é o caso de pagamento e recebimento de juros, que poderiam estar em financiamento e investimento, respectivamente. Um outro ponto interessante é que nessa classificação não entram movimentações virtuais, como a aquisição de imobilizado a prazo, que mesmo sem ter passado pelo caixa no primeiro momento, poderia ser classificada como entrada de financiamento e saída de investimento, mas entram apenas os pagamentos do financiamento, que é o que realmente movimenta caixa.

\subsubsection{Relações entre Renda tributável e fluxos de Caixa TRIBUTÁVEIS}

Tomando como base a classificação do FASB, podemos verificar que os fluxos de caixa das Atividades Operacionais têm correspondência com seus respectivos itens que compõem a renda dos proprietários, o que significa que esses fluxos podem ser tributados. Isso inclui não só os pagamentos a 
fornecedores e governo e recebimentos de clientes, mas também juros e dividendos recebidos e juros pagos sobre empréstimos. Uma única consideração deve ser feita a respeito dos dividendos recebidos: se a tributação ocorrer na empresa geradora dos dividendos, esses valores não podem estar novamente sujeitos a nova tributação. É o que ocorre atualmente no Brasil: o pagamento de dividendos é isento de imposto na fonte.

Observando a composição dos fluxos de caixa das Atividades de Investimento, verificamos que são saídas e entradas de caixa referentes a ativos de longo prazo, inclusive aos classificados no Brasil como Permanentes.

A aquisição desses ativos não representa aumento ou diminuição do patrimônio, o que significa que não há renda tributável nesse momento. A renda proveniente dessa aquisição só será observada em termos de caixa quando houver sua realização financeira.

Essa realização financeira pode ocorrer por meio da obtenção de recebimentos (e realização de pagamentos necessários para isso) com o uso desses ativos ou pela venda dos mesmos.

Recebimentos e pagamentos que ocorrem por conta do uso dos ativos são operacionais e representam renda de forma direta.

Por outro lado, é mais complicado observar a renda derivada dos ativos por meio dos fluxos de caixa na sua venda, porque o patrimônio só é afetado pela diferença entre o valor de realização e o de aquisição. No fundo, a venda é também um uso, mas de todo o ativo residual. 0 problema é verificar 0 resultado desse uso. Em base competência, isso é o ganho ou perda na venda 
do ativo. Em base caixa, é necessário verificar os pagamentos que foram realizados para adquiri-lo e contrapô-los aos recebimentos pela venda e eventuais gastos necessários para efetuar a venda.

Como os pagamentos pela aquisição ocorrem normalmente em períodos diferentes que os recebimentos, é necessário deduzir os pagamentos da base de cálculo do tributo e depois acrescentar os recebimentos pela venda.

No final das contas, seria tributada ou deduzida apenas a diferença, mas o abatimento dos pagamentos, que ocorrem normalmente antes dos recebimentos, pode provocar uma postergação do imposto a pagar. Em base competência, os ativos imobilizados são depreciados, havendo uma alocação dessa saída de caixa aos períodos de sua vida útil, o que diminui o impacto temporal sobre os tributos. Os demais investimentos têm apenas os ganhos ou perdas oferecidos à tributação, não entrando para essa base toda a saída e a entrada de caixa.

Em relação aos fluxos de caixa das Atividades de Financiamento, as entradas e saídas de capital próprio ou de terceiros não representam geração de renda por parte da empresa, não sendo desse modo sujeitos à tributação.

Entretanto, há um fluxo nesse grupo que merece atenção: o de pagamento de dividendos. Poderia-se pensar na hipótese de se tributar apenas esses valores, uma vez que a renda está relacionada ao aumento do patrimônio do investidor. Contudo, além das diferenças competência/caixa, há eventuais diferenças entre o valor tributável correspondente à renda e os dividendos pagos. Essas diferenças podem resultar de políticas de distribuição ou de 
reinvestimento. Pode ser que a política da empresa, em determinado momento, defina que os proprietários devem reinvestir seus lucros, o que reduz o fluxo de dividendos. Isso significa que, se a tributação ocorresse com base nos dividendos pagos, poder-se-ia deixar de tributar toda a renda, uma vez que o reinvestimento é a utilização da renda obtida e que não necessariamente se tornará renda no futuro. Desse modo, a melhor forma seria apurar os fluxos que correspondem à renda e formar a base de cálculo do imposto, ao invés de tributar diretamente o valor dos dividendos pagos.

Em síntese, são itens que devem compor o fluxo de caixa tributável líquido aqueles que têm correspondência com a renda, que representam efetivamente aumentos no investimento dos proprietários, mas em base caixa.

A renda apurada em base caixa perde o sentido que Hicks quis dar ao seu conceito, uma vez que o valor da renda de uma semana é o que o indivíduo poderia consumir sem se empobrecer, o que transmite a idéia de base competência.

Sem dúvida, a melhor forma de apurar a renda é calcular o lucro nessa base, porque assim é possível mostrar o que foi ganho no período, independentemente da realização financeira disso.

A apuração do valor tributável em base caixa não pode servir como referência de renda para o propósito que Hicks queria. Sua apuração atende ao objetivo de tributação porque há uma correspondência com os itens que compõem a renda, mas isso não significa que esse valor também corresponda à renda do período. 
Desse modo, o valor dos fluxos de caixa tributáveis do período não é o valor da renda do período, embora haja uma correspondência entre eles. A disparidade entre ambos é apenas temporal, mas isso faz toda a diferença para efeitos de decisão do indivíduo que investiu na empresa.

O tratamento mais detalhado dos itens que compõem o fluxo de caixa tributável será feito no próximo capítulo. 


\section{DESENVOLVIMENTO DO MODELO}

\subsection{INTRODUÇÃO}

Neste capítulo são explorados os aspectos relacionados à estruturação do modelo de tributação da renda sobre os fluxos de caixa: o que deve ser tributado, os ajustes e outros aspectos técnicos.

Os aspectos teóricos que foram abordados no capítulo anterior são aqui tratados de um modo mais aplicado, analisando o modelo atual de tributação da renda no Brasil com base no lucro e posteriormente estruturando o modelo de tributação da renda em base caixa, levando em conta determinadas características do modelo atual e os aspectos teóricos.

Para que possa ser analisada ao longo da leitura, propomos, como regra geral, que o modelo seja alicerçado nas seguintes bases:

- Todas as entradas de caixa geradas pelo ativo ou provenientes de sua realização devem ser tributadas, operacionais ou não;

- Todas as saídas de caixa necessárias para pagar um ativo adquirido devem ser dedutíveis;

- Os pagamentos de juros gerados pelos passivos devem ser dedutíveis.

Assim, no desenvolvimento do modelo, vamos procurar testar essa regra geral e explicar porque deve ser ou não dessa forma, além de definir outras questões inerentes ao modelo de tributação, como o fato gerador e a alíquota. 
Desse modo, serão analisados nos próximos tópicos a tributação atual sobre a renda no Brasil, para posteriormente se fazer a transposição para o modelo baseado nos fluxos de caixa.

\subsection{A TRIBUTAÇÃO ATUAL SOBRE A RENDA NO BRASIL}

O Imposto de Renda (IR) no Brasil é objeto de volumosa e mutável legislação. Além do IR, há também a Contribuição Social sobre o Lucro (CS), que tem praticamente a mesma base de incidência.

A base de caracterização desses tributos é o Regulamento do Imposto de Renda de 1999 (RIR/99), válido para o presente ano, somado às regulamentações posteriores e ao Código Tributário Nacional.

O objetivo deste tópico é levantar as principais características do atual modelo de tributação que possam servir como base para o desenvolvimento do modelo de tributação da renda com base nos fluxos de caixa.

\subsubsection{Competência, Função e fato Gerador}

A competência do Imposto de Renda é da União Federal. De acordo com Machado ${ }^{59}$, o tributo deve ser mesmo dessa competência:

"Justifica-se que seja esse imposto de competência federal porque só assim pode ser utilizado como instrumento de

\footnotetext{
${ }^{59}$ MACHADO, Hugo de Brito. Curso de direito tributário, p. 272.
} 
redistribuição de renda, buscando manter em equilibrio $o$ desenvolvimento econômico das diversas regiões".

O imposto de renda é atualmente a principal fonte de receita tributária da União, o que Ihe confere função fiscal. Entretanto, também é utilizado como instrumento de política econômica, por meio de incentivos fiscais regionais, o que Ihe dá também função extrafiscal.

Nas três modalidades de apuração dos tributos diretos, o fato gerador é o mesmo. A aquisição da disponibilidade econômica ou jurídica não significa necessariamente a realização em numerário. Basta que a pessoa obtenha um conjunto de bens, valores e/ou títulos que sejam passíveis de serem transformados em dinheiro.

A apuração da renda tributável, via de regra, ocorre em base competência. Assim, mesmo que não se tenha recebido pela venda do produto ou serviço, a pessoa tem sua renda reconhecida e deve ser tributada. A exceção à regra fica por conta da tributação pelo lucro presumido: a receita bruta pode ser calculada em regime caixa.

\subsubsection{Base de Cálculo}

A seguir, descrevemos com maiores detalhes as três modalidades de apuração do lucro tributável: Lucro Presumido, Lucro Arbitrado e Lucro Real. 


\section{Lucro Presumido}

O objetivo da criação da modalidade de tributação pelo Lucro Presumido foi o de facilitar a apuração da base de cálculo. As pessoas jurídicas optantes por essa modalidade estão dispensadas, para efeito de apuração do IR/CS (mas não perante o código civil e o comercial), da obrigatoriedade da escrituração contábil. Podem optar por esta modalidade empresas que têm faturamento anual de até $\mathrm{R} \$ 48$ milhões.

Uma parte da base de cálculo do Imposto de Renda é o que podemos chamar de "lucro das operações", calculado de forma presumida sobre a receita bruta. A legislação presume que esse lucro é um percentual da receita bruta, que pode variar de $1,6 \%$ a $32 \%$, dependendo da atividade realizada pela pessoa jurídica.

Na legislação tributária, há uma definição toda própria de receita bruta. Ela não inclui o IPI (Imposto sobre Produtos Industrializados), o ICMS (Imposto sobre Circulação de Mercadorias e Serviços) referente a Substituição Tributária, as vendas canceladas e as devoluções e os descontos incondicionais concedidos.

O "lucro das operações" para a CS é calculado em $12 \%$ sobre a mesma receita bruta do IR, independentemente da atividade exercida pela empresa.

Além desse "lucro das operações", incluem-se na base de cálculo do IR e da CS:

- Ganhos de capital, demais receitas e resultados positivos; 
- Rendimentos de operações de mútuo;

- Ganhos em operações de hedge;

- Receita de locação de imóvel;

- Variações monetária ativas;

- Receita financeira, quando não tributado na fonte.

Nessa modalidade de tributação, a apuração dos valores é feita trimestralmente.

\section{Lucro Arbitrado}

A base de cálculo do Lucro Arbitrado é obtida a partir da aplicação de um percentual incidente sobre a receita bruta, quando conhecida, ou, quando não conhecida, com base no valor do ativo, do capital social, do patrimônio líquido, da folha de pagamentos de empregados, das compras, do aluguel das instalações ou do lucro líquido auferido pelo contribuinte em períodos-base anteriores.

\section{Lucro Real}

A base de cálculo do Lucro Real é o lucro contábil ajustado por adições, exclusões e compensações. O lucro contábil é apurado com base na escrituração, atendendo aos princípios contábeis geralmente aceitos, com ativos avaliados a custo histórico. 
Atualmente, a empresa pode fazer duas opções para a apuração do Lucro Real: apurar em cada trimestre ou anualmente. Se a opção for pela apuração do Lucro Real trimestral, as demonstrações devem ser levantadas ao final de cada trimestre.

Na opção pelo Lucro Real anual, as PJ devem efetuar recolhimentos mensais com base em estimativas, como uma espécie de adiantamento ao governo do imposto devido, com a possibilidade de suspensão ou redução do imposto com base em balanços ou balancetes periódicos. Se o lucro apurado nos balancetes for menor que o calculado por estimativa, a PJ pode reduzir 0 imposto a ser pago. A estimativa é calculada com a aplicação de percentuais sobre a receita bruta, assim como ocorre na sistemática de Lucro Presumido. A eventual diferença entre o montante devido no ano e o valor já pago pela estimativa deve ser paga na declaração do IR.

A legislação também permite que, no cômputo do Lucro Real, sejam deduzidos os juros sobre capital próprio, calculados com a Taxa de Juros de Longo Prazo, divulgada pelo Banco Central, sobre o Patrimônio Líquido da empresa. Esse valor não pode ser maior que $50 \%$ do lucro do período ou $50 \%$ dos lucros acumulados (dos dois o maior). Essa dedução é facultativa para a empresa.

Tanto pela apuração do Lucro Real trimestral como na anual, podem existir adições, exclusões e compensações que alteram a base de cálculo.

As adições são os ajustes que se somam à base de cálculo, e referem-se a: 
- $\quad$ custos, despesas, encargos, perdas, provisões, participações e quaisquer outros valores contabilizados que não são dedutíveis do IR/CS por força da legislação tributária, tais como o resultado negativo de equivalência patrimonial, excesso de depreciação e a constituição de provisões não dedutíveis, como para devedores duvidosos, contingências, desvalorização de estoques etc.;

- resultados, rendimentos, receitas e quaisquer outros valores não incluídos na apuração do lucro contábil que, de acordo com a legislação tributária, devam ser computados na determinação do Lucro Real, como a realização da reserva de reavaliação, os valores não tributados para aumento de capital social, e o lucro inflacionário realizado;

- depreciação apurada contabilmente de bem já integralmente depreciado em virtude de incentivos fiscais previstos.

As exclusões referem-se a valores que devem ser subtraídos da base de cálculo, relacionados a:

- quantias dedutíveis que não tenham sido computados na apuração do lucro contábil, como a depreciação acelerada incentivada;

- $\quad$ resultados positivos e quaisquer outros valores incluídos na apuração do lucro contábil que, de acordo com a legislação tributária, não devem ser computados no Lucro Real, como o lucro na exportação de manufaturados amparada por Programa Befiex, resultado positivo de equivalência patrimonial e lucro inflacionário não realizado; e

- $\quad$ prejuízos de exercícios anteriores. 
As compensações de prejuízos fiscais referem-se à possibilidade de redução do Lucro Real apurado no período-base utilizando o prejuízo fiscal apurado em períodos-base anteriores, anuais ou trimestrais.

A compensação pode ser de no máximo $30 \%$ do lucro ajustado pelas adições e exclusões. No caso de apuração pelo Lucro Real trimestral, o lucro tributável apurado num trimestre só pode ser reduzido em até $30 \%$ com prejuízos fiscais anteriores e não pode compensar prejuízos de trimestres subseqüentes, mesmo dentro do próprio ano.

\subsubsection{Alíquotas}

Se a opção de tributação da empresa for Lucro Presumido ou Lucro Real, a alíquota normal do IR é a mesma, de 15\% sobre a base de cálculo.

No caso do Lucro Arbitrado, as alíquotas podem variar de acordo com a base de cálculo estabelecida e a atividade da PJ.

Além da alíquota normal de IR, há o Adicional de IR, com alíquota de $10 \%$ sobre a parcela da base de cálculo que exceder o limite do equivalente a $\mathrm{R} \$ 20.000,00$ por mês.

Na opção pelo Lucro Real, sobre a base de cálculo das estimativas mensais também são aplicadas as mesmas alíquotas.

A CS tem alíquota de $9 \%$ sobre a sua base de cálculo, sem adicional. 


\subsubsection{Valor do Imposto a PAgar}

O valor resultante da aplicação das alíquotas sobre a base de cálculo dos tributos pode ainda ser deduzido do IRRF sobre receitas, do saldo de IR pago a maior ou indevidamente em períodos anteriores e dos incentivos fiscais.

O valor dos dividendos ou lucros distribuídos é isento de imposto, não havendo qualquer retenção na fonte pagadora, qualquer que seja a opção de tributação da empresa.

\subsubsection{INCENTIVOS FISCAIS}

Os incentivos fiscais podem ser separados em três categorias: de renúncia fiscal, isenção e imunidade.

O governo faz uma renúncia fiscal quando abre mão de parte da arrecadação para incentivar determinadas atividades ou regiões geográficas. Isso pode ocorrer de duas formas: por dedução do imposto devido e por incentivos fiscais regionais.

A primeira forma consiste na dedução do valor obtido com a aplicação da alíquota do imposto sobre os gastos relacionados ao programa incentivado diretamente do imposto de renda devido, além de sua dedução como despesa operacional. Atualmente existem o Programa de Alimentação do Trabalhador (PAT), os Programas de Desenvolvimento Tecnológico Industrial (PDTI), os Programas de Desenvolvimento Tecnológico Agropecuário (PDTA), o Programa 
Nacional de Apoio à Cultura (PRONAC) e o incentivo às atividades audiovisuais. O valor total das doações aos Fundos dos Direitos da Criança e do Adolescente pode ser deduzido do imposto devido, embora não seja dedutível como despesa operacional na determinação do Lucro Real.

Em relação aos incentivos fiscais regionais, a pessoa jurídica pode aplicar parte do IRPJ nos fundos regionais - Nordeste (FINOR), Amazônia (FINAM) e ao Estado do Espírito Santo (FUNRES), dentro dos limites percentuais determinados em lei. Outro incentivo para a área do Nordeste e da Amazônia é o depósito de parte do imposto nas áreas de atuação da Sudam e da Sudene para reinvestimento. Além disso, é possível ter direito ao crédito de parte do IRRF sobre remessas ao exterior em pagamento de royalties, assistência técnica ou científica e de serviços especializados, em contratos vinculados ao PDTI ou PDTA.

Atualmente há isenções para a Zona Franca de Manaus e Amazônia Ocidental e para parte do lucro de exploração nas regiões Norte, Nordeste e Centro-Oeste. No caso da Zona Franca de Manaus e Amazônia Ocidental, as isenções se referem a imposto de importação e IPI na aquisição, do imposto de exportação nas mercadorias para o exterior e do IPI caso se destinem a consumo interno.

São imunes os partidos políticos, entidades sindicais, as instituições de educação e de assistência social sem fins lucrativos, desde que atendidos os requisitos da lei. 


\subsection{ANÁLISE DO MODELO DE TRIBUTAÇÃO ATUAL}

\subsubsection{LuCro Presumido e ARbitrado}

O Lucro Arbitrado serve como instrumento de apoio à fiscalização e como referência ao contribuinte do que pode acontecer se não atender às exigências do fisco.

O Lucro Presumido claramente atende a uma necessidade de simplificação do processo de apuração do imposto, pois não é necessário o levantamento dos custos e despesas do período, já que é apurado basicamente sobre as receitas da firma. Ele é voltado para as pequenas empresas, em função do limite de faturamento imposto pelo fisco para a sua adoção.

Por outro lado, a opção pode acabar não sendo vantajosa para empresas que têm uma lucratividade apurada contabilmente abaixo dos percentuais de presunção do lucro.

Isso pode ir contra o princípio da capacidade contributiva, uma vez que a opção deve ser feita no início do ano, sem a possibilidade de mudança durante o mesmo período. Se a empresa tiver prejuízo ou baixa lucratividade ao longo do ano, ela terá que pagar o imposto mesmo gerando renda abaixo do presumido pelo governo. 


\subsubsection{LUCRO REAL}

A opção pelo Lucro Real é obrigatória para as empresas que não podem optar pelo Presumido. Para aquelas que podem optar, o Lucro Real é vantajoso apenas para as que têm uma lucratividade média abaixo da que é presumida.

A base de cálculo do Lucro Real tem como componente principal o lucro contábil antes do IR/CS, o que significa que a sua apuração é em base competência.

Entretanto, determinados ajustes (adições e exclusões) obrigatórios revelam que há um conflito competência/caixa, como é o caso das provisões. Estas devem ser reconhecidas quando de sua incorrência, mas devem ser adicionadas nesse momento e apenas reconhecidas para efeito tributário quando ocorrer a sua realização (de acordo com as regras fiscais). Exemplo: suponha que uma empresa tenha reconhecido um passivo contingencial trabalhista. Esse valor só poderá ser deduzido do imposto quando de seu efetivo pagamento.

A razão para essa política tributária é simples: evitar manipulações que possam reduzir o imposto a pagar artificialmente. Para isso, o fisco adota o diferimento dessas deduções, colocando o reconhecimento desses gastos mais próximo da base caixa, que é mais conservadora e livre dos problemas de estimativa. Por causa disso, não é possível dizer que a base de cálculo dos tributos é inteiramente em base competência, mas apenas próximo disso. 
Além de ser apenas próximo à base competência, a atual definição de base de cálculo também impõe que a avaliação dos ativos seja pelo custo histórico, ao invés de custo histórico corrigido, como era na sistemática baseada na Lei 6.404/76, com a metodologia de Correção Monetária de Balanço, uma vez que não permite que qualquer resultado decorrente de inflação seja considerado em sua base, mesmo que positivo.

Os juros sobre capital próprio são uma dedução opcional que surgiu juntamente com a proibição da correção monetária. Foi uma forma de tentar compensar os efeitos decorrentes disso. Além do problema contábil de comparabilidade em função de ser opcional, sua sistemática de cálculo não consegue fazer paralelo com o verdadeiro sentido econômico de custo de oportunidade do capital próprio. Ademais, como visto no capítulo anterior, o custo de capital próprio não deve ser considerado no cômputo da renda tributável, por fazer parte dela.

Fora as adições e exclusões, a base também pode ser determinada pelas compensações. A atual política de permitir a compensação de apenas $30 \%$ do lucro tributável é também uma forma de não prejudicar a arrecadação, uma vez que o governo estará recebendo sempre pelo menos o imposto referente a $70 \%$ do lucro. 0 total acumulado das compensações não é reajustado pela inflação. Isso diminui, em termos reais, o valor a que tem direito o contribuinte de abater o prejuízo fiscal. O efeito disso é um aumento na carga tributária da empresa que eventualmente apresente prejuízos fiscais e que volte a apresentar lucros. 
Os incentivos fiscais são objeto de deliberação do governo, que renuncia à arrecadação em favor do desenvolvimento de determinadas regiões geográficas ou de determinadas atividades. As imunidades existem para entidades que, além do interesse público inerente, não geram renda para ser tributada, no sentido de que não são unidades economicamente produtivas. Os incentivos, portanto, não fazem parte da estrutura principal do modelo de tributação, no sentido de que, qualquer que seja a forma de apuração do tributo, os incentivos continuarão sendo objeto de deliberação do governo.

A apuração mensal de IR/CS pelo Lucro Real Anual com base nas estimativas foi a forma encontrada pelo governo de ter arrecadações durante 0 ano sem ter que obrigar o contribuinte a incorrer em maiores custos de conformidade para apurar os tributos mensalmente. Entretanto, na prática o que ocorre é que parte das empresas acaba tendo que ter esses gastos de qualquer maneira, uma vez que para conseguir a suspensão ou redução do imposto é necessário fazer a apuração contábil mês a mês. Por essa sistemática, empresas que apresentam prejuízo acabam tendo que ter maiores custos de conformidade para pagar o imposto devido.

A sistemática de ter os dividendos e os lucros distribuídos isentos de tributação está de acordo com a noção de que o lucro é a renda dos proprietários. Entretanto, essa noção não deve ter sido o guia para a estruturação dessa sistemática, porque em anos anteriores o lucro distribuído era tributado. 
Em relação às alíquotas dos tributos, cabe destacar a questão do Adicional de IR. É uma forma de trazer progressividade à tributação da pessoa jurídica, uma vez que só pagam aquelas que têm lucro superior a um patamar, o que é interessante do ponto de vista de capacidade contributiva. 0 problema é que esse patamar não é reajustado pela inflação, fazendo com que a cada ano mais empresas estejam sujeitas a pagar o adicional.

\subsection{A TRANSPOSIÇÃO PARA O MODELO DE TRIBUTAÇÃO DA RENDA COM BASE NO FLUXO DE CAIXA}

\subsubsection{Visão GeraL}

Como visto, a tributação atual sobre a renda da pessoa jurídica é baseada no lucro apurado contabilmente.

Em função dos problemas apontados no Capítulo 1, desenvolvemos, neste capítulo, um modelo de tributação da renda baseada nos fluxos de caixa, como uma alternativa ao modelo baseado no lucro.

Assim, é feita uma transposição do modelo com base em lucro para o modelo com base em caixa, acompanhando a mesma estrutura apresentada na descrição do modelo atual.

Quando necessário, estão sendo feitas relações entre o modelo proposto e o modelo atual de tributação caracterizado anteriormente. 


\subsubsection{Competência, Função e Fato Gerador}

A competência do tributo e sua função não devem ser alteradas com o modelo com base nos fluxos de caixa, porque mesmo que haja mudança para este modelo, o tributo não pode deixar de ter sua característica de redistribuição de renda, o que deve ser feito em nível nacional.

No modelo baseado em fluxos de caixa, o fato gerador deixa de ser a aquisição da disponibilidade econômica ou jurídica da renda e de proventos de qualquer natureza, como é no modelo baseado no lucro. O fato gerador passa a ser a aquisição da disponibilidade financeira da renda e de proventos de qualquer natureza. A disponibilidade financeira não deixa de ser também disponibilidade econômica ou jurídica, mas a posição no tempo pode ser diferente, tanto antes como depois.

Isso significa que, neste modelo, o fato gerador do imposto passa a ser o recebimento e o pagamento, e não a obtenção de um conjunto de bens, valores e/ou títulos que sejam passíveis de transformação em dinheiro.

Contabilmente, isso significa a troca do regime de competência pelo regime de caixa para a apuração dos tributos.

\subsubsection{Base de Cálculo}

O modelo baseado em fluxos de caixa realizados apenas se contrapõe ao modelo de tributação do Lucro Real, uma vez que os modelos de Lucro 
Presumido e Arbitrado são simplificações cuja base é a Receita Bruta. Se fôssemos transpor esses modelos para fluxos de caixa, a base passaria a ser o valor dos recebimentos operacionais, e continuaria apresentando o mesmo problema de poder não atender ao princípio da capacidade contributiva.

Assim, o modelo em base caixa é uma transposição do modelo em base competência, com base de cálculo computada a partir do lucro contábil ajustado, o Lucro Real.

As movimentações de caixa ocorridas em um período são compostas por uma série de entradas e saídas, mas nem sempre de mesma natureza. Entradas de dinheiro em função de uma venda têm implicações diferentes das entradas pela obtenção de empréstimos, por exemplo. O primeiro representa um componente da renda; a segunda não.

Apenas para reforçar, relembramos as bases da regra geral, proposta no início do capítulo:

- Todas as entradas de caixa geradas pelo ativo ou provenientes de sua realização devem ser tributadas, operacionais ou não;

- Todas as saídas de caixa necessárias para pagar um ativo adquirido devem ser dedutíveis;

- Os pagamentos de juros gerados pelos passivos devem ser dedutíveis.

Essa regra geral será testada nos próximos tópicos, procurando explicar porque deve ser ou não dessa forma, analisando os diversos tipos de fluxos e quais devem compor a base de cálculo do tributo sobre a renda. 


\subsection{FLUXOS DE CAIXA TRIBUTÁVEIS}

\subsubsection{FluXos de Caixa Operacionais}

Como visto no capítulo anterior, os fluxos de caixa que correspondem à renda podem ser tributados. Para o desenvolvimento do modelo, vamos tratar da renda como a diferença entre dois patrimônios do investidor, mas do ponto de vista do que é proveniente dos ativos e dos passivos. O motivo para isso é a relação que deve ser feita entre os fluxos de caixa tributáveis e os ativos, em função da necessidade de testar a regra geral proposta anteriormente.

Se há uma correspondência entre os Fluxos de Caixa das Atividades Operacionais (de acordo com a classificação do FASB, vista no capítulo anterior) e o lucro contábil, eles são tributáveis. A partir disso, vamos analisar se a regra geral proposta é válida.

Os recebimentos pela venda de produtos ou serviços correspondem às receitas geradas pelos ativos, em base caixa. Para realizar a venda, foi necessário o consumo e a entrega de ativos por parte da empresa. Se a venda foi realizada a prazo, foi criado um outro ativo, o Contas a Receber, que no vencimento deve se transformar em dinheiro. Desse modo, essas entradas de caixa geradas pelo ativo são tributáveis. Os juros embutidos nas vendas a prazo funcionam como receitas financeiras e os seus recebimentos também deve ser tributados. 
Os insumos adquiridos, inclusive serviços, permanecem no ativo até que sejam entregues aos clientes. Nesse meio tempo, eles podem ser transformados, beneficiados, montados ou passar por qualquer processo, mas continuam no ativo. Os pagamentos desses ativos, que podem ter sido adquiridos a vista ou a prazo, correspondem aos custos, que são reduções da renda, e devem diminuir os fluxos de caixa tributáveis.

Os pagamentos referentes a salários também são decorrentes do consumo de serviços de uma espécie de ativos que não são contabilizados na avaliação por custo histórico: os recursos humanos.

Outros fluxos negativos de caixa como os relacionados a despesas de venda e administração também são para pagar a aquisição de ativos cujo benefício ocorre no presente, para a obtenção de receitas.

O mesmo raciocínio de tributar os fluxos de caixa decorrentes dos ativos também precisa ser aplicado aos ativos de longo prazo e permanentes.

No momento da aquisição de um realizável a longo prazo com dinheiro, o fluxo negativo de caixa não aumenta nem diminui o total do ativo. Apenas eventuais juros devem aumentar a renda do período. Para que a tributação em base caixa ocorra apenas sobre esses juros, é necessário que ela seja efetuada sobre a diferença entre as entradas e saídas de caixa. Para isso, é preciso deduzir a saída de caixa pela aquisição do ativo e tributar a entrada dos juros e do recebimento do principal, mesmo que no decorrer do tempo esse valor tenha passado do longo prazo para o curto. A regra geral continua valendo para essa situação. 
Apesar de não ser uma saída de caixa que seja necessária para pagar um ativo, e sim um passivo, os juros pagos devem ser dedutíveis, pois eles representam uma redução da renda dos investidores.

\subsubsection{FluXos de Caixa de Investimentos}

No ativo imobilizado, o raciocínio é idêntico ao dos ativos de longo prazo (aliás, o imobilizado não deixa de ser um ativo de longo prazo): as saídas de caixa para a aquisição do imobilizado devem reduzir a base de cálculo do tributo. $\mathrm{O}$ uso desse ativo irá gerar receitas, cujos recebimentos irão aumentar o fluxo de caixa tributável do período.

O mesmo ocorre quando a renda tributável é calculada sobre o lucro em base competência: a depreciação é dedutível. Isso decorre do fato de que a depreciação é a alocação do caixa pago no investimento em função da não recuperabilidade dos ativos ao resultado do período, em confronto com as receitas que foram obtidas. Em termos econômicos, essa depreciação deveria corresponder à efetiva perda de capacidade de geração de benefícios futuros durante o período, cujo comportamento pode variar ao longo dos períodos, ao contrário da sistemática que normalmente se adota na prática, aplicando-se uma taxa de depreciação fixa sobre o custo histórico do ativo.

Se tomarmos, hipoteticamente, todo o ciclo de vida de um empreendimento que tenha um único ativo fixo adquirido no momento 0 , a depreciação de cada período seria uma fração do valor do custo desse ativo. Ao 
término da vida do empreendimento, todo o custo deveria ter sido alocado aos diversos períodos sejam eles quantos forem. Isso ocorre sob o princípio do custo como base de valor. No término do ciclo de vida, todo o ativo terá se transformado em caixa.

Em termos econômicos, o valor desse ativo corresponde ao que ele irá gerar de benefícios no futuro. Entenda-se isso como o que esse ativo poderá gerar de fluxos positivos de caixa no futuro. No mesmo exemplo, esse valor corresponderia às diferenças entre todos os recebimentos e pagamentos efetuados durante todo o empreendimento. O lucro do empreendimento seria a diferença do que foi investido no imobilizado e o que foi gerado por ele.

Uma saída de caixa pelo investimento em ativo imobilizado é como se fosse um "gasto antecipado", necessário para que haja recursos operacionais para gerar fluxos de caixa no futuro.

Desse modo, as saídas de caixa pelo investimento em ativo imobilizado podem ser deduzidas dos tributos diretos a pagar.

As entradas de caixa decorrentes da venda de imobilizado nada mais são do que antecipações do que se poderia obter de fluxos de caixa no futuro com o ativo. Se esses fluxos seriam tributados no futuro, a antecipação também deve ser tributada.

Como exemplo, tomemos uma empresa com os seguintes eventos:

- Abertura da empresa com imobilizado no valor de $\$ 13.000$, com vida útil de 3 períodos, com valor residual de $\$ 1.000$;

- Venda de imobilizado no final do período 2 por $\$ 5.300$; 
- Aquisição de novo imobilizado por $\$ 5.000$, com vida útil de 1 período, no início do período 3, com valor residual de $\$ 1.000$.

Seu balanço patrimonial ficaria da seguinte forma:

Tabela 4.1 - Balanço Patrimonial com Imobilizado

\begin{tabular}{lcccc} 
BP & $\mathbf{0}$ & $\mathbf{1}$ & $\mathbf{2}$ & $\mathbf{3}$ \\
\hline Caixa & & 7.000 & 19.300 & 21.300 \\
Imobilizado & 13.000 & 9.000 & - & 1.000 \\
& & & & \\
Capital & 13.000 & 13.000 & 13.000 & 13.000 \\
Lucros Acum. & & 3.000 & 6.300 & 9.300 \\
\hline
\end{tabular}

A Demonstração de Resultados evidenciaria o seguinte:

Tabela 4.2 - DRE com resultado na venda de imobilizado

\begin{tabular}{|c|c|c|c|c|c|}
\hline DRE & $\mathbf{0}$ & 1 & 2 & 3 & TOTAL \\
\hline Receitas & & 25.000 & 25.000 & 25.000 & 75.000 \\
\hline Custos & & $(18.000)$ & $(18.000)$ & (18.000) & $(54.000)$ \\
\hline Despesa Depreciação & & $(4.000)$ & $(4.000)$ & $(4.000)$ & $(12.000)$ \\
\hline Res. Venda Imobil. & & & 300 & & 300 \\
\hline Lucro Líquido & & 3.000 & 3.300 & 3.000 & 9.300 \\
\hline
\end{tabular}

$\mathrm{Na}$ Demonstração dos Fluxos de Caixa, separamos os fluxos operacionais, os de investimento e os de financiamento, mas destacamos 0 Fluxo Líquido Tributável, formado pelos fluxos operacionais e de investimento:

\begin{tabular}{|c|c|c|c|c|c|}
\hline DFC & $\mathbf{0}$ & 1 & 2 & 3 & TOTAL \\
\hline Recebimentos & & 25.000 & 25.000 & 25.000 & 75.000 \\
\hline Pagamentos & & $(18.000)$ & $(18.000)$ & $(18.000)$ & $\begin{array}{c}(54.000) \\
-\end{array}$ \\
\hline Aquisição Imobilizado & $(13.000)$ & - & - & $(5.000)$ & $(18.000)$ \\
\hline Venda Imobilizado & & - & 5.300 & - & 5.300 \\
\hline Fluxo Cx. Tributável & $(13.000)$ & 7.000 & 12.300 & 2.000 & 8.300 \\
\hline Aumento de Capital & 13.000 & - & - & - & \\
\hline Var. Líquida Caixa & - & 7.000 & 12.300 & 2.000 & 21.300 \\
\hline
\end{tabular}

Podemos observar que o fluxo de caixa tributável (FCT) não coincide com o total de lucros. A diferença de $\$ 1.000$ (\$9.300 - \$8.300) está no valor 
residual do imobilizado. O FCT somente irá corresponder ao acréscimo patrimonial (lucro) quando todos os ativos se realizarem em forma de caixa. A diferença entre FCT e lucro está nos ativos ainda não realizados, como é o caso do residual do imobilizado.

É interessante observar também um outro aspecto relacionado ao imobilizado. Suponhamos que a depreciação fosse de acordo com o valor de mercado do bem, como demonstrado abaixo:

\begin{tabular}{lccccc}
\multicolumn{5}{c}{ Tabela 4.4 - Depreciação com ativos a valor de mercado } \\
& $\mathbf{0}$ & $\mathbf{1}$ & $\mathbf{2}$ & $\mathbf{3}$ \\
\hline Valor de Mercado & 13.000 & 7.000 & 5.300 & 1.000 \\
& & & & \\
Valor Contábil & 13.000 & 13.000 & 13.000 & 13.000 \\
Depreciação Acum. & - & $(6.000)$ & $(7.700)$ & $(12.000)$ \\
\hline & 13.000 & 7.000 & 5.300 & 1.000 \\
\hline
\end{tabular}

Nessa suposição, a DRE ficaria da seguinte forma:

Tabela 4.5 - DRE com depreciação de ativos a valor de mercado

\begin{tabular}{|c|c|c|c|c|c|}
\hline DRE & $\mathbf{0}$ & 1 & 2 & 3 & TOTAL \\
\hline Receitas & & 25.000 & 25.000 & 25.000 & 75.000 \\
\hline Custos & & $(18.000)$ & $(18.000)$ & $(18.000)$ & $(54.000)$ \\
\hline Despesa Depreciação & & $(6.000)$ & $(1.700)$ & $(4.000)$ & $(11.700)$ \\
\hline Res. Venda Imobil. & & & - & & - \\
\hline Lucro Líquido & & 1.000 & 5.300 & 3.000 & 9.300 \\
\hline
\end{tabular}

Pode-se observar que no momento 2 não há um resultado na venda de imobilizado, em função da forma como fora calculada a despesa de depreciação. Por outro lado, a DFC ficará exatamente igual ao anterior, porque o recebimento pela venda do imobilizado continuará o mesmo.

Isso mostra que qualquer que seja o método de depreciação, o fluxo de caixa tributável será o mesmo. Além disso, verifica-se que ganhos ou perdas na 
venda do imobilizado são operacionais, pois se o método de depreciação for diferente, o resultado na venda também será diferente.

Desse modo, a regra geral continua valendo, porque a saída de caixa para pagar o ativo imobilizado deve ser dedutível, assim como as entradas pela venda do ativo devem ser tributáveis, do mesmo modo como são as receitas operacionais geradas pelo uso do imobilizado.

Vamos analisar agora uma outra situação: o ativo imobilizado não foi adquirido à vista, mas com financiamento do próprio fornecedor. Nesse caso, a geração de caixa positivo continua da mesma forma. Entretanto, as saídas de caixa só ocorrerão no pagamento das parcelas do financiamento, mas não deixam de ser dedutíveis, uma vez que a depreciação desse imobilizado ocorreria da mesma forma, independentemente da forma de pagamento. No modelo de DFC do FASB, esses pagamentos são classificados como fluxos de caixa das atividades de financiamento. Contudo, neste modelo de tributação, essas saídas devem estar contidas no cômputo da base de cálculo. Isso demonstra que a regra geral é também válida para essa situação, embora implique na modificação da forma de classificação dos fluxos dentro da DFC.

Se a empresa tomar um financiamento em dinheiro para a aquisição de imobilizado, apenas a saída de caixa para a compra é que deverá ser dedutível. Os pagamentos do financiamento não poderão ser novamente dedutíveis. Do financiamento, apenas os juros pagos devem ser dedutíveis.

O FCT também corresponderá ao lucro quando todos os ativos se realizarem em caixa no caso de Investimentos, no Ativo Permanente. Quando 
os investimentos estão avaliados pelo método de equivalência patrimonial, há o reconhecimento do resultado na controladora em função da variação no patrimônio líquido da controlada.

No seguinte exemplo, uma subsidiária é controlada em 100\% por uma empresa, e distribui $75 \%$ do lucro do período anterior. O balanço e a DRE da controlada ficam desta forma:

Tabela 4.6 - Balanço e DRE de Controlada $100 \%$

\begin{tabular}{lcccc} 
BP Controlada 100\% & $\mathbf{0}$ & $\mathbf{1}$ & $\mathbf{2}$ & $\mathbf{3}$ \\
\hline Caixa & & 4.000 & 5.000 & 6.000 \\
Imobilizado & 10.000 & 10.000 & 10.000 & 10.000 \\
& & & & \\
Capital & 10.000 & 10.000 & 10.000 & 10.000 \\
Lucros Acum. & & 4.000 & 5.000 & 6.000 \\
\hline & & & \\
DRE Controlada 100\% & & 6.000 & 6.000 & 6.000 \\
Receitas & & $(2.000)$ & $(2.000)$ & $(2.000)$ \\
Custos Mão-de-Obra & & 4.000 & 4.000 & 4.000 \\
Lucro Líquido & & &
\end{tabular}

O balanço e a DRE da controladora ficam da seguinte forma:

Tabela 4.7 - Balanço da controladora

\begin{tabular}{lcccc} 
BP Controladora & $\mathbf{0}$ & $\mathbf{1}$ & $\mathbf{2}$ & $\mathbf{3}$ \\
\hline Caixa & & 7.000 & 17.000 & 27.000 \\
Investimentos & 10.000 & 14.000 & 15.000 & 16.000 \\
Imobilizado & 30.000 & 30.000 & 30.000 & 30.000 \\
& & & & \\
Capital & 40.000 & 40.000 & 40.000 & 40.000 \\
Lucros Acum. & & 11.000 & 22.000 & 33.000 \\
\hline
\end{tabular}

\section{Tabela 4.8 - DRE da controladora}

\begin{tabular}{lccccc} 
DRE Controladora & $\mathbf{0}$ & $\mathbf{1}$ & $\mathbf{2}$ & $\mathbf{3}$ & TOTAL \\
\hline Receitas & 12.000 & 12.000 & 12.000 & 36.000 \\
Custos Mão-de-Obra & & $(5.000)$ & $(5.000)$ & $(5.000)$ & $(15.000)$ \\
Res. Equivalência Patr. & 4.000 & 4.000 & 4.000 & 12.000 \\
Lucro Líquido & 11.000 & 11.000 & 11.000 & 33.000 \\
\hline
\end{tabular}


Na DFC da controladora, apresentada abaixo, é possível verificar o recebimento de dividendos, classificado aqui dentro do FCT, assim como a aquisição dos investimentos.

\begin{tabular}{lccccc}
\multicolumn{7}{c}{ Tabela 4.9 - DFC da controladora } \\
DFC Controladora & $\mathbf{0}$ & $\mathbf{1}$ & $\mathbf{2}$ & $\mathbf{3}$ & TOTAL \\
\hline Recebimentos & & 12.000 & 12.000 & 12.000 & 36.000 \\
Pagamentos & & $(5.000)$ & $(5.000)$ & $(5.000)$ & $(15.000)$ \\
Dividendos Recebidos & & & 3.000 & 3.000 & 6.000 \\
& & & & & \\
Aquisição Investimentos & $(10.000)$ & - & - & - & $(10.000)$ \\
$\begin{array}{l}\text { Aquisição Imobilizado } \\
\text { Fluxo Cx. Tributável }\end{array}$ & $(30.000)$ & - & - & - & $(30.000)$ \\
\cline { 2 - 7 } & $\mathbf{( 4 0 . 0 0 0 )}$ & $\mathbf{7 . 0 0 0}$ & $\mathbf{1 0 . 0 0 0}$ & $\mathbf{1 0 . 0 0 0}$ & $\mathbf{( 1 3 . 0 0 0 )}$ \\
$\begin{array}{l}\text { Aumento de Capital } \\
\text { Var. Líquida Caixa }\end{array}$ & 40.000 & - & - & - & 40.000 \\
& - & $\mathbf{7 . 0 0 0}$ & $\mathbf{1 0 . 0 0 0}$ & $\mathbf{1 0 . 0 0 0}$ & $\mathbf{2 7 . 0 0 0}$
\end{tabular}

Nota-se que o FCT também não coincide com o lucro líquido total. A diferença de $\$ 43.000$ [\$33.000 - (-13.000)] está nos dividendos não recebidos, que aumentaram a conta de investimentos via resultado de equivalência patrimonial, e nos saldos iniciais de investimentos e imobilizado, que não se realizaram em caixa. Isso significa que, enquanto esses ativos de longo prazo não se realizarem em caixa, o FCT não coincidirá com o lucro.

No caso de investimentos, não faria diferença se a empresa estivesse fazendo a contabilização pelo método de custo, porque no fluxo de caixa entram apenas os recebimentos de dividendos e os pagamentos pela aquisição das participações.

Do mesmo modo, o Diferido, composto por gastos que serão amortizados no futuro em função de seus benefícios ainda não obtidos, deve ter os pagamentos que o formam dedutíveis no período em que são efetuados. As receitas derivadas são operacionais, e tributáveis normalmente. 


\subsubsection{Movimentações ViRTUAis de CAIXA}

Agora, analisaremos alguns problemas para o modelo de tributação com base no fluxo de caixa: determinadas situações em que a regra geral não é válida. São algumas das movimentações virtuais de caixa: transações que não representam entradas ou saídas de dinheiro.

Vamos imaginar uma situação em que o proprietário tenha aberto o capital da empresa com imobilizado, ao invés de dinheiro. Esse imobilizado irá depreciar normalmente, gerando despesas dedutíveis. Entretanto, não houve e não haverá futuras saídas de caixa por conta do ativo adquirido. Isso significa que, pela regra geral, esse ativo poderia não ser dedutível, apenas pelo fato de ter sido originado dos recursos do proprietário, o que está errado.

Uma outra situação que ocorre de modo invertido: devolução de capital com entrega de imobilizado. Sem esse ativo, a empresa tenderá a ter uma geração operacional de caixa menor e ficará sem a possibilidade de obter receita com a venda do residual. Assim, a empresa teria a dedução do imposto na aquisição, mas não seria tributado na entrega ao proprietário que está se retirando da sociedade.

Qualquer transação que envolva o aumento ou diminuição de um ativo não-caixa com contrapartida em uma conta de Patrimônio Líquido torna inválida a regra geral. São transações do seguinte tipo: aumento de capital com estoques, bens obtidos por doações, devolução de capital com entrega de estoques ou imobilizado etc. 
Nesses casos, a única saída para fazer com que o valor desses ativos seja dedutível ou tributável é fazer um ajuste na base de cálculo do tributo. Isso pode ser feito de duas maneiras:

- Evidenciar a movimentação virtual na própria DFC que sirva de base para a tributação. Assim, na transação de aumento de capital com imobilizado, haveria uma entrada de caixa nas atividades de financiamento e uma saída de mesmo valor nas atividades de investimento, sendo que este último comporia a base de cálculo do tributo;

- Manter a DFC apenas com as movimentações reais e fazer ajustes em livro separado, a exemplo do que acontece com o Lalur (Livro de Apuração do Lucro Real).

Há outras movimentações virtuais de caixa, mas elas não estão envolvidas no reconhecimento da renda por meio dos fluxos de caixa. São as movimentações entre ativos não-caixa e entre passivos não-caixa. Exemplo: um ativo imobilizado é vendido a prazo, gerando um contas a receber. Essa transação pode provocar o reconhecimento de um ganho ou perda em base competência, mas em base caixa isso só irá se concretizar quando houver uma outra transação: o recebimento, que é tributável. Do lado do passivo, pode haver uma conversão de debêntures em ações. Essa transação não representa aumento nem diminuição do patrimônio dos investidores, apenas a proporção capital de terceiros/próprio irá se alterar. 


\subsubsection{INFLAÇÃo}

Atualmente, a legislação tributária não permite o reconhecimento dos efeitos inflacionários sobre o resultado tributável. Certamente isso provoca distorções, podendo levar a uma despesa com IR/CS maior ou menor em relação ao que deveria ser com o reconhecimento, em função dos montantes de itens monetários expostos à inflação durante o período.

Sendo permitido ou não o reconhecimento dos efeitos inflacionários, é necessário verificar como eles deveriam ser reconhecidos nesse modelo de tributação por fluxos de caixa.

Primeiramente é necessário analisar a sistemática que deveria ser aplicada para o reconhecimento da inflação nesse modelo.

A inflação somente teria efeito sobre o Fluxo de Caixa Tributável se fossem aplicados os conceitos de correção monetária integral sobre o caixa. A sistemática de correção monetária de balanço não produziria o reconhecimento necessário dos resultados com a inflação. Isso ocorre porque esta sistemática reconheceria os efeitos inflacionários pela contraposição da correção das contas de ativo permanente e patrimônio líquido. O resultado dessa contraposição aparece em uma única linha na DRE, ajustando o lucro do período. Todas as demais contas de resultado e as contas patrimoniais que não de ativo permanente e patrimônio líquido não sofreriam qualquer tipo de ajuste em função da inflação. 
Pela sistemática de correção integral, todas as contas patrimoniais e de resultado seriam corrigidas e os resultados decorrentes de ganhos ou perdas nos itens monetários, expostos à inflação, seriam apurados.

Com os tributos sendo calculados a partir do FCT, há a necessidade de serem reconhecidos os efeitos inflacionários sobre a movimentação de caixa.

Para mostrar isso, suponhamos o seguinte exemplo, com estas premissas:

- A empresa foi aberta com capital de $\$ 8.000$, com receitas de $\$ 7.000$ a receber em 1 período, durante dois períodos, e custos/despesas de $\$ 3.900$ a vista;

- Não será considerado o ajuste a valor presente do contas a receber.

Abaixo, estão o Balanço Patrimonial nos quatro períodos e a DRE, sem considerar a inflação dos períodos:

Tabela 4.10 - Balanço e DRE sem inflação

Balanço sem Inflação

\begin{tabular}{lcllc}
\hline & $\mathbf{0}$ & $\mathbf{1}$ & $\mathbf{2}$ & $\mathbf{3}$ \\
\cline { 2 - 5 } Caixa & 8.000 & 4.100 & 7.200 & 14.200 \\
C. Receber & & 7.000 & 7.000 & \\
Capital & 8.000 & 8.000 & 8.000 & 8.000 \\
Lucros Ac. & & 3.100 & 6.200 & 6.200 \\
\hline
\end{tabular}

\begin{tabular}{lcccc} 
DRE sem Inflação & \multicolumn{5}{c}{} \\
\hline & $\mathbf{0}$ & $\mathbf{1}$ & $\mathbf{2}$ & $\mathbf{3}$ \\
\cline { 2 - 5 } Receitas & - & 7.000 & 7.000 & - \\
Custos/Desp. & - & $(3.900)$ & $(3.900)$ & - \\
\cline { 2 - 5 } & - & 3.100 & 3.100 & - \\
\hline
\end{tabular}

Agora, serão aplicados os seguintes índices de inflação para reconhecer os ganhos e perdas nos itens monetários: 


\begin{tabular}{cc} 
Tabela 4.11 - Índices de inflação aplicados \\
Final Período 0 & 1,00 \\
Final Período 1 & 1,10 \\
Final Período 2 & 1,21 \\
Final Período 3 & 1,33 \\
\hline
\end{tabular}

A seguir, é apresentada a apuração de cada período, em moeda de final do próprio, com suas respectivas DRE's. Para apurar o ganho ou perda, foi refeita toda a movimentação em moeda constante de Caixa e Contas a Receber, que são os itens monetários do exemplo. A partir disso, foi calculado o saldo que deveria existir (SQDE), que, comparado ao saldo existente (SE), resulta nos ganhos ou perdas.

\begin{tabular}{|c|c|c|}
\hline & Caixa & C. Receber \\
\hline Saldo Inicial & 8.800 & - \\
\hline Vendas & & 7.000 \\
\hline Custos/Desp. & $(3.900)$ & \\
\hline SQDE & 4.900 & 7.000 \\
\hline SE & 4.100 & 7.000 \\
\hline Ganho (Perda) & $(800)$ & - \\
\hline
\end{tabular}

Tabela 4.13 - DRE do Período 1 em CMI

\begin{tabular}{lc} 
& Período 1 \\
\cline { 2 - 2 } Receitas & 7.000 \\
Custos/Desp. & $(3.900)$ \\
Perdas Caixa & $(800)$ \\
G/P C. Receber & - \\
\cline { 2 - 2 } Lucro Líquido & $\mathbf{2 3 0 0}$ \\
\hline
\end{tabular}

Tabela 4.14 - Ganhos e Perdas do Período 2 em Moeda de Final de 2

\begin{tabular}{lcc} 
& Caixa & C. Receber \\
\cline { 2 - 3 } Saldo Inicial & 4.510 & 7.700 \\
Recebimentos & 7.000 & $(7.000)$ \\
Vendas & & 7.000 \\
Custos/Desp. & $(3.900)$ & \\
\cline { 2 - 3 } SQDE & 7.610 & 7.700 \\
SE & 7.200 & 7.000 \\
\cline { 2 - 3 } Ganho (Perda) & $\mathbf{( 4 1 0 )}$ & $\mathbf{( 7 0 0 )}$ \\
\hline
\end{tabular}


Tabela 4.15 - DRE do Período 2 em CMI

\begin{tabular}{lc} 
& Período 2 \\
\cline { 2 - 2 } Receitas & 7.000 \\
Custos/Desp. & $(3.900)$ \\
Perdas Caixa & $(410)$ \\
G/P C. Receber & $(700)$ \\
\cline { 2 - 2 } Lucro Líquido & $\mathbf{1 9 9 0}$ \\
\hline
\end{tabular}

Tabela 4.16 - Ganhos e Perdas do Período 3 em Moeda de Final de 3

\begin{tabular}{lrc} 
& Caixa & C. Receber \\
\cline { 2 - 3 } Saldo Inicial & 7.914 & 7.694 \\
Recebimentos & 7.000 & $(7.000)$ \\
Vendas & & \\
Custos/Desp. & & \\
\cline { 2 - 3 } SQDE & 14.914 & 694 \\
SE & 14.200 & - \\
Ganho (Perda) & $\mathbf{( 7 1 4 )}$ & $\mathbf{( 6 9 4 )}$ \\
\hline
\end{tabular}

Tabela 4.17 - DRE do Período 3 em CMI

\begin{tabular}{lc} 
& Período 3 \\
\cline { 2 - 2 } Receitas & - \\
Custos/Desp. & - \\
Perdas Caixa & $(714)$ \\
G/P C. Receber & $(694)$ \\
\cline { 2 - 2 } Lucro Líquido & $\mathbf{( 1 . 4 0 8 )}$ \\
\hline
\end{tabular}

Convertendo as DRE's em moeda do final do Período 3, temos:

Tabela 4.18 - DRE em Moeda de Final do Período 3

\begin{tabular}{lcccc} 
& Período 1 & Período 2 & Período 3 & Total \\
\cline { 2 - 5 } Receitas & 8.464 & 7.694 & - & 16.158 \\
Custos/Desp. & $(4.715)$ & $(4.287)$ & - & $(9.002)$ \\
Perdas Caixa & $(967)$ & $(451)$ & $(714)$ & $(2.132)$ \\
G/P C. Receber & - & $(769)$ & $(694)$ & $(1.464)$ \\
\cline { 2 - 5 } Lucro Líquido & $\mathbf{2 . 7 8 1}$ & $\mathbf{2 . 1 8 7}$ & $\mathbf{( 1 . 4 0 8 )}$ & $\mathbf{3 . 5 6 0}$
\end{tabular}

Elaborando as DFC's dos três períodos, já em moeda constante do final do período 3, temos o seguinte: 


\begin{tabular}{lcccccc} 
Tabela 4.19 - DFC dos Três Períodos em Moeda de Final do Período 3 \\
& & Período 0 & Período 1 & Período 2 & Período 3 & \multicolumn{1}{c}{ Total } \\
\cline { 2 - 6 } Recebimentos & - & - & 7.694 & 7.000 & 14.694 \\
Pagamentos & - & $(4.715)$ & $(4.287)$ & - & $(9.002)$ \\
Perdas Caixa & & $(967)$ & $(451)$ & $(714)$ & $(2.132)$ \\
\cline { 2 - 6 } Geração Op. Cx. & - & $\mathbf{( 5 . 6 8 3 )}$ & $\mathbf{2 . 9 5 7}$ & $\mathbf{6 . 2 8 6}$ & $\mathbf{3 . 5 6 0}$ \\
& & & & & \\
Abertura Capital & 10.640 & - & - & - & 10.640 \\
& & & & & \\
Saldo Inicial & - & $\mathbf{1 0 . 6 4 0}$ & $\mathbf{4 . 9 5 7}$ & $\mathbf{7 . 9 1 4}$ & \\
Saldo Final & $\mathbf{1 0 . 6 4 0}$ & $\mathbf{4 . 9 5 7}$ & $\mathbf{7 . 9 1 4}$ & $\mathbf{1 4 . 2 0 0}$ & \\
\hline
\end{tabular}

Pode-se observar que a Geração Operacional de Caixa Total de \$3.560 é igual ao lucro líquido total, em moeda constante. Eles são iguais porque o lucro apurado periodicamente acaba se transformando em caixa. Os ganhos ou perdas no Contas a Receber que são reconhecidos no lucro tem também reflexo no fluxo de caixa, mas por meio de recebimentos maiores ou menores em termos reais. Do mesmo modo, isso aconteceria com os custos e despesas, se eles fossem pagos a prazo.

Da mesma forma acontece com os itens monetários dos fluxos de investimento, como as aplicações financeiras, que têm seus ganhos e perdas computados com o recebimento das receitas financeiras e pela diferença entre os valores aplicados e resgatados.

Assim, apenas as perdas inflacionárias no caixa é que aparecem de forma destacada na DFC, resultantes dos saldos intermediários mantidos no caixa.

Se forem feitos ajustes a valor presente em itens monetários pré-fixados, a DFC continuará a mesma porque esses ajustes são apenas temporais, para 
atendimento ao princípio de competência na alocação dos juros embutidos aos períodos, e também irão se realizar em caixa.

Se houvesse algum fluxo de caixa de investimentos, como visto anteriormente, ele teria que ser também somado à geração operacional de caixa para coincidir com o lucro líquido.

Entretanto, a geração operacional de caixa total e o fluxo de caixa de investimentos só irão coincidir com o Lucro Líquido se houver plena correspondência entre os itens considerados no resultado e os itens desses fluxos de caixa.

Isso não vai acontecer quando houver resultados inflacionários decorrentes de itens que têm pagamentos e recebimentos classificados no fluxo de caixa de financiamento, como é o caso de empréstimos. Os juros pagos estão classificados no fluxo de caixa operacional, mas os ganhos ou perdas inflacionários com os empréstimos são observados na DFC apenas pela diferença entre as entradas e saídas de caixa.

Isso pode ser verificado no seguinte exemplo: suponha que ao invés de capital próprio, a empresa do exemplo anterior tenha começado com um financiamento de $\$ 8.000$, que será pago em uma única vez no final do período 3, e que os juros nominais pagos já estejam contidos nos custos e despesas de $\$ 3.900$.

Apurados os ganhos e perdas em cada período, chegamos ao seguinte resultado nos três períodos, já em moeda do final do período 3. 
Tabela 4.20 - DRE dos Três Períodos em Moeda de Final do Período 3

\begin{tabular}{lcccc} 
& Período 1 & Período 2 & Período 3 & Total \\
\cline { 2 - 5 } Receitas & 8.464 & 7.694 & - & 16.158 \\
Custos/Desp. & $(4.715)$ & $(4.287)$ & - & $(9.002)$ \\
Perdas Caixa & $(967)$ & $(451)$ & $(714)$ & $(2.132)$ \\
G/P C. Receber & - & $(769)$ & $(694)$ & $(1.464)$ \\
Ganho Financ. & 967 & 879 & 793 & 2.640 \\
\cline { 2 - 5 } Lucro Líquido & $\mathbf{3 . 7 4 8}$ & $\mathbf{3 . 0 6 7}$ & $\mathbf{( 6 1 5 )}$ & $\mathbf{6 . 2 0 0}$
\end{tabular}

O fluxo de caixa dessas operações é o seguinte, já em moeda do final do período 3 e com as perdas no caixa:

Tabela 4.21 - DFC dos Quatro Períodos e Com Perdas no Caixa DFC em Moeda de Final de 3

\begin{tabular}{lccccc} 
& Período 0 & Período 1 & Período 2 Período 3 & Total \\
\cline { 2 - 6 } Recebimentos & - & - & 7.694 & 7.000 & 14.694 \\
Pagamentos & - & $(4.715)$ & $(4.287)$ & - & $(9.002)$ \\
Perdas Caixa & & $(967)$ & $(451)$ & $(714)$ & $(2.132)$ \\
\cline { 2 - 6 } Geração Op. Cx. & - & $\mathbf{( 5 . 6 8 3 )}$ & $\mathbf{2 . 9 5 7}$ & $\mathbf{6 . 2 8 6}$ & $\mathbf{3 . 5 6 0}$ \\
& & & & & \\
Empréstimos & 10.640 & - & - & $(8.000)$ & 2.640 \\
& & & & & \\
Saldo Inicial & - & $\mathbf{1 0 . 6 4 0}$ & $\mathbf{4 . 9 5 7}$ & $\mathbf{7 . 9 1 4}$ & \\
Saldo Final & $\mathbf{1 0 . 6 4 0}$ & $\mathbf{4 . 9 5 7}$ & $\mathbf{7 . 9 1 4}$ & $\mathbf{6 . 2 0 0}$ & \\
\hline
\end{tabular}

Nessa DFC, estamos considerando que os pagamentos de juros, que estão contidos nos pagamentos dentro da geração operacional de caixa, estão pelos seus valores nominais, uma vez que foi assim que passaram pelo caixa. Assim, o ganho inflacionário sobre os empréstimos não poderia estar sendo computado dentro do operacional, mesmo que ele fosse apurado, porque não há um fluxo de recebimento ou pagamento disso. No fluxo de caixa, esse ganho será reflexo de um pagamento menor, em termos reais, do empréstimo. No exemplo, o ganho total em financiamentos de $\$ 2.640$, observado na DRE, corresponde à diferença entre o valor obtido com a dívida $(\$ 10.640)$ e o seu pagamento (\$8.000), observado na DFC. 
Se somarmos os $\$ 3.560$ de geração operacional de caixa com os $\$ 2.640$ da diferença de caixa do financiamento, obtemos $\$ 6.200$, que corresponde ao lucro líquido.

Se esse ganho ou perda com os itens monetários que serão pagamentos classificados no fluxo de caixa de financiamento não for considerado, o fluxo de caixa tributável não irá corresponder ao lucro tributável. Com isso, é necessário fazer um ajuste nesse fluxo com o valor desse ganho ou perda.

Se não forem reconhecidos os resultados com a inflação, assim mesmo o caixa e o lucro seriam iguais ao final das atividades da empresa, como constata Martins $^{60}$.

Entretanto, isso acontece quando se considera que os recebimentos e pagamentos têm o mesmo valor em qualquer forma de avaliação dos lucros. Quando o imposto de renda é calculado com base no lucro sem correção, evidentemente ele terá valor diferente do calculado sobre o lucro que tem como base o método de avaliação dos ativos a custo histórico corrigido. Assim, a correspondência Caixa/Lucro é válida quando há consistência na metodologia de cálculo dos valores.

No caso da tributação pelos fluxos de caixa, o não reconhecimento dos efeitos inflacionários tem como resultado a efetiva modificação da base de cálculo do tributo, podendo ser maior ou menor que a base sem os efeitos inflacionários, dependendo da composição dos itens monetários.

${ }^{60}$ MARTINS, Eliseu (org.). Avaliação de empresas: da mensuração contábil à econômica, p. $340-1$. 
O problema de não serem reconhecidos os efeitos inflacionários sobre a base de cálculo dos tributos está na sua forma de apuração, que é periódica. Os resultados ocorrem ao longo de um período, e no seu final é apurado o tributo devido. Se não forem ajustados pela inflação, a base de cálculo será formada pelo somatório de valores obtidos em datas diferentes, com moedas de poder aquisitivo diferentes. A situação é piorada quanto maior for o período de apuração.

\subsection{FLUXOS DE CAIXA NÃO-TRIBUTÁVEIS}

Definidos os fluxos tributáveis do modelo, devemos definir os nãotributáveis. Seguindo o mesmo raciocínio, não devem ser tributáveis quaisquer valores que não representam aumento do patrimônio do investidor.

Assim, em base competência, apenas o que não representa lucro não deveria ser tributado. Todo o resto deveria entrar para a base de cálculo.

Sob o ponto de vista de caixa, não deveriam ser tributadas as entradas de caixa referentes a capital de terceiros e próprio, como obtenção de empréstimos e aumento de capital. Do mesmo modo, saídas de caixa referentes a amortização de empréstimos, devoluções de capital, juros sobre capital próprio, também não podem ser dedutíveis.

Isso não significa que não possam ser criados mecanismos alternativos que sirvam como instrumento de política tributária, como é o caso dos juros sobre capital próprio. Se fossem dedutíveis, a exemplo do que acontece 
atualmente, isso poderia favorecer empresas mais capitalizadas, dependendo da taxa utilizada, podendo tornar indiferente a forma de captação de recursos.

\subsection{ALÍQUOTA}

Há algumas considerações a fazer sobre a alíquota que deve ser aplicada sobre a base de cálculo dos tributos.

Como visto anteriormente, se for aplicada a mesma alíquota sobre bases de cálculo equivalentes em termos de lucro e fluxo de caixa, o total de tributos arrecadados sobre todo o empreendimento é igual em ambos os métodos.

Há ainda uma consideração importante a fazer a respeito da alíquota, que é a do valor do dinheiro no tempo.

É da natureza dos empreendimentos que os investimentos (saídas de caixa) ocorram antes das entradas de caixa que representam o retorno do investimento. Com as saídas ocorrendo antes das entradas, haverá um acúmulo de tributos a compensar no início do empreendimento, com pagamentos maiores no seu final. Considerando o valor do dinheiro no tempo, é preferível para o governo ter recebimentos de tributos antes a depois. Em função disso, a alíquota poderia até aumentar, na razão das taxas de juros vigentes. 


\subsection{DEDUÇÕES DO IMPOSTO A PAGAR}

Nesse modelo de tributação da renda, há cinco tipos de ajustes a se fazer para o cômputo dos tributos a pagar. São eles:

- o valor dos tributos pagos no período - o valor pago referente ao período anterior deve ser adicionado à base de cálculo, pois se isso não ocorrer, a alíquota precisa ser maior para igualar a arrecadação. Além disso, o valor do imposto, ao longo do tempo, tende a se estabilizar em torno de uma média, supondo uma geração de caixa constante, mas nunca será um valor constante;

- os fluxos de caixa não-tributáveis, desde que já não tenham sido desconsiderados no cômputo da base de cálculo;

- saídas de caixa não dedutíveis em função de penalidades fiscais - multas por infração tributária têm sido consideradas indedutíveis pela legislação atual;

- incentivos fiscais - há duas formas atualmente. A primeira ocorre na forma de ajustes na base de cálculo, como os incentivos regionais (FINOR, FINAM e FUNRES) ou à exportação. A segunda se dá com ajustes sobre o valor do tributo, como é o caso dos incentivos à cultura.

- Compensação de fluxos negativos anteriores - o valor dos tributos a pagar deve ser descontado dos fluxos negativos acumulados, para que 0 contribuinte não seja sobretaxado nos retornos sobre os investimentos realizados no passado que provocaram os fluxos negativos ou prejudicado 
em ciclos de alta que compensam ciclos de baixa produção. Pode haver deliberação do fisco em permitir compensar apenas parte do acumulado em cada período, para aumentar a arrecadação nos primeiros períodos.

Em função desses ajustes, é necessário existir um livro em que eles fiquem registrados, a exemplo do LALUR, como existe na atual sistemática.

\subsection{CAIXA E EQUIVALENTES CAIXA}

Para a elaboração do fluxo de caixa realizado, é preciso determinar a composição do que se deve considerar nos saldos iniciais e finais da DFC. Se considerarmos apenas caixa mesmo, ou seja, disponibilidade em espécie, toda a movimentação contida na DFC deve tomar como referência essa conta. Assim, depósitos e saques bancários também seriam fluxos a serem destacados. Se os saldos iniciais e finais da DFC forem compostos por caixa e bancos, os depósitos e saques não iriam aparecer.

Se os saldos da DFC forem compostos apenas por dinheiro em espécie, apenas as movimentações com essa conta é que irão compor a DFC, diminuindo a relevância da informação (e também a base de cálculo do imposto), pois normalmente a maior parte da movimentação da empresa ocorre por movimentação bancária.

Se os saldos da DFC forem compostos por caixa e bancos, toda a movimentação de aplicações e resgates de curtíssimo prazo irá aparecer no fluxo, sendo também questionável a relevância dessa informação. 
A vantagem adicional de ter os saldos compostos por caixa, bancos e aplicações financeiras de curtíssimo prazo é que eles são conciliáveis com os saldos apresentados no balanço. Além disso, os juros creditados na conta de aplicação financeira irão aparecer destacados, não havendo a necessidade, com isso, de apurar esses ganhos por diferença entre aplicações e resgates.

\subsection{EXEMPLO DE TRIBUTAÇÃO POR FLUXOS DE CAIXA}

Neste tópico, foi elaborado um exemplo de tributação pelos fluxos de caixa com o objetivo de reunir as partes do modelo analisadas até agora.

Primeiramente, é apresentada a forma como se tributa atualmente pelo Lucro Real. Depois, é demonstrada a base de cálculo do imposto por fluxos de caixa e o imposto devido com ajustes.

No exemplo, foram feitas as seguintes considerações e realizaram-se os seguintes eventos:

- A empresa realizou suas atividades em 4 períodos;

- as vendas realizadas são recebidas sempre no período seguinte;

- as compras de fornecedores são pagas no período seguinte;

- os estoques iniciais são todos vendidos no período;

- as despesas administrativas são pagas no próprio período em que são incorridas;

- no período 0 foi feita uma aplicação financeira, que rendeu juros nos períodos 1 e 2 de $10 \%$ e foi resgatada no período 4. Essa aplicação 
financeira não está considerada no saldo de Caixa e Equivalente Caixa, por não ser de curtíssimo prazo;

- foi tomado um empréstimo em 0 , a ser pago em 3 parcelas, com juros pagos no período de $5 \%$ sobre o saldo inicial de empréstimos;

- metade da depreciação do período refere-se à produção, sendo considerados como custos do período. O restante foi considerado como despesa, destacada em conta própria;

- A alíquota de imposto de renda é de $15 \%$ e a de contribuição social é de 9\% sobre o LAIR/CS, considerando que não houve adições ou exclusões no Lucro Real.

Inicialmente, vamos comparar a tributação pelo lucro com a tributação pelo fluxo de caixa sem considerar a inflação. Depois, vamos realizar a apuração dos tributos a partir dos fluxos tributáveis corrigidos monetariamente, considerando os ganhos e perdas com o caixa e com os itens monetários dos fluxos não-tributáveis.

A movimentação do estoque fica da seguinte forma:

\begin{tabular}{lcccc} 
Tabela 4.22 & Movimentação de & Estoques nos Quatro Períodos \\
ESTOQUES & $\mathbf{0}$ & $\mathbf{1}$ & $\mathbf{2}$ & $\mathbf{3}$ \\
\hline Estoque Inicial & - & 2.500 & 2.500 \\
Compras & 2.500 & 2.500 & - \\
Depreciação & & 1.500 & 1.500 \\
Saídas & & $(4.000)$ & $(4.000)$ \\
Estoque Final & 2.500 & 2.500 & - \\
\hline
\end{tabular}

A partir disso, é possível montar a seguinte DRE, com o imposto calculado com base no lucro: 
Tabela 4.23 - Impostos Calculados com Base no Lucro dos Quatro Periodos

\begin{tabular}{|c|c|c|c|c|}
\hline DRE & 0 & 1 & 2 & 3 \\
\hline Receita de Vendas & & 15.000 & 15.000 & \\
\hline Custos & & $(4.000)$ & $(4.000)$ & \\
\hline Despesas Administr. & & (800) & (800) & \\
\hline Receitas Financeiras & & 100 & 110 & \\
\hline Despesas Financ. & & (150) & $(100)$ & \\
\hline Despesas Deprec. & & $(1.500)$ & $(1.500)$ & \\
\hline LAIR/CS & & 8.650 & 8.710 & \\
\hline IR/CS $15 \%+9 \%$ & & $(2.076)$ & $(2.090)$ & \\
\hline Lucro Líquido & & 6.574 & 6.620 & \\
\hline
\end{tabular}

Já o Balanço teria os seguintes números:

Tabela 4.24 - Balanço dos Quatro Períodos

\begin{tabular}{lcrcc} 
BP & $\mathbf{0}$ & $\mathbf{1}$ & $\mathbf{2}$ & $\mathbf{3}$ \\
\hline Caixa & 5.000 & 550 & 9.074 & 22.194 \\
Aplic. Financeiras & 1.000 & 1.100 & 1.210 & - \\
Contas Receber & & 15.000 & 15.000 & \\
Estoques & 2.500 & 2.500 & - & \\
Imobilizado & 6.000 & 6.000 & 6.000 & 6.000 \\
Deprec. Acumulada & & $(3.000)$ & $(6.000)$ & $(6.000)$ \\
\cline { 2 - 5 } & $\mathbf{1 4 . 5 0 0}$ & $\mathbf{2 2 . 1 5 0}$ & $\mathbf{2 5 . 2 8 4}$ & $\mathbf{2 2 . 1 9 4}$ \\
& & & & \\
Fornecedores & 2.500 & 2.500 & - & - \\
IR/CS a Pagar & & 2.076 & 2.090 & - \\
Empréstimos & 3.000 & 2.000 & 1.000 & - \\
Capital & 9.000 & 9.000 & 9.000 & 9.000 \\
Lucros Acumulados & & 6.574 & 13.194 & 13.194 \\
\cline { 2 - 5 } & $\mathbf{1 4 . 5 0 0}$ & $\mathbf{2 2 . 1 5 0}$ & $\mathbf{2 5 . 2 8 4}$ & $\mathbf{2 2 . 1 9 4}$ \\
\hline
\end{tabular}

Apenas para fechar a forma como ficaria a empresa se a tributação fosse pelo lucro, demonstramos a DFC de toda essa movimentação: 
Tabela 4.25 - DFC dos Quatro Períodos

\begin{tabular}{|c|c|c|c|c|c|}
\hline DFC & 0 & 1 & 2 & 3 & TOTAL \\
\hline \multicolumn{6}{|l|}{ Atividades Operac. } \\
\hline Recebimento Vendas & & & 15.000 & 15.000 & 30.000 \\
\hline Recebimento Juros & & & & 210 & 210 \\
\hline Pagamento Fornec. & & $(2.500)$ & $(2.500)$ & & $(5.000)$ \\
\hline Pagto. Desp. Adm. & & $(800)$ & $(800)$ & & $(1.600)$ \\
\hline Pagto. IR / CS & & & $(2.076)$ & $(2.090)$ & $(4.166)$ \\
\hline \multirow[t]{2}{*}{ Pagto de Juros } & & $(150)$ & $(100)$ & & $(250)$ \\
\hline & - & $(3.450)$ & 9.524 & 13.120 & 19.194 \\
\hline \multicolumn{6}{|l|}{ Atividades Investim. } \\
\hline Aplic.Financ. /Resg. & $(1.000)$ & & & 1.000 & - \\
\hline \multirow[t]{2}{*}{ Aquis. Imobilizado } & $(6.000)$ & & & & $(6.000)$ \\
\hline & $(7.000)$ & - & - & 1.000 & $(6.000)$ \\
\hline \multicolumn{6}{|l|}{ Atividades Financ. } \\
\hline Empréstimos & 3.000 & $(1.000)$ & $(1.000)$ & $(1.000)$ & - \\
\hline \multirow[t]{2}{*}{ Capital } & 9.000 & & & & 9.000 \\
\hline & 12.000 & $(1.000)$ & $(1.000)$ & $(1.000)$ & 9.000 \\
\hline Variação Líq. Caixa & 5.000 & $(4.450)$ & 8.524 & 13.120 & 22.194 \\
\hline Saldo Inicial & - & 5.000 & 550 & 9.074 & - \\
\hline Saldo Final & 5.000 & 550 & 9.074 & 22.194 & 22.194 \\
\hline
\end{tabular}

Adaptando toda essa movimentação para a tributação com base nos fluxos de caixa, teríamos a seguinte apuração: 
Tabela 4.26 - Apuração dos Tributos com Base nos Fluxos de Caixa Tributáveis

DFC

\section{Fluxo Caixa Tribut.}

Recebimento Vendas

Recebimento Juros

Pagamento Fornec.

Pagto. Desp. Adm.

Pagto. IR / CS

Pagto de Juros

Aplic.Financ. /Resg.

Aquis. Imobilizado

Ajustes

FI.Caixa Tribut.Aj.

IR/CS Devido

IR/CS a Compensar

IR/CS a Pagar
0 1 2

4 TOTAL

(n)

.

-
-
$(2.500)$
$(800)$
-

(1.000)

(6.000)

(7.000)

15.000

15.000

210

(2.500)

(800)

(100)
30.000

210

(5.000)

(276) (3.890)
(6.000)

1.000

13.194

\begin{tabular}{rrrrrr} 
& & - & 276 & 3.890 & 4.166 \\
\hline $\mathbf{( 7 . 0 0 0 )}$ & $\mathbf{( 3 . 4 5 0 )}$ & $\mathbf{1 1 . 6 0 0}$ & $\mathbf{1 6 . 2 1 0}$ & - & $\mathbf{1 7 . 3 6 0}$ \\
\hline
\end{tabular}

\begin{tabular}{cccccc}
$(1.680)$ & $(828)$ & 2.784 & 3.890 & - & 4.166 \\
1.680 & 2.508 & - & - & - & - \\
- & - & 276 & 3.890 & - & 4.166 \\
\hline
\end{tabular}

FI.Caixa Não Tribut.

Empréstimos

Capital

\begin{tabular}{rrrrrr}
3.000 & $(1.000)$ & $(1.000)$ & $(1.000)$ & - & - \\
9.000 & - & - & - & - & 9.000 \\
\hline 12.000 & $(1.000)$ & $(1.000)$ & $(1.000)$ & - & 9.000 \\
& & & & & \\
- & 5.000 & 550 & 11.150 & $\mathbf{2 6 . 0 8 4}$ & - \\
5.000 & 550 & $\mathbf{1 1 . 1 5 0}$ & $\mathbf{2 6 . 0 8 4}$ & $\mathbf{2 2 . 1 9 4}$ & $\mathbf{2 2 . 1 9 4}$ \\
\hline
\end{tabular}

Saldo Inicial 5.000 550 11.150 26.084

É possível observar que essa DFC foi modificada, ficando separada em dois fluxos: os Fluxos de Caixa Tributáveis (FCT) e os Fluxos de Caixa Não Tributáveis. Dentro do FCT, foi feito o único ajuste do exemplo, que é o próprio imposto pago, referente ao período anterior, resultando no Fluxo de Caixa Tributável Ajustado.

Sobre esse valor, foi aplicada a alíquota do IR/CS, a mesma de $24 \%$. $(15 \%+9 \%)$, resultando no IR/CS devido. Quanto este valor está negativo, acumula-se ao IR/CS a compensar. Só irá haver IR/CS a pagar quando o IR/CS devido for maior que o valor a compensar acumulado. 
Assim, é possível verificar que a empresa só terá IR/CS devido quando tem geração positiva de caixa tributável: $\$ 516$ no período 2 e $\$ 3.600$ no período 3, totalizando os mesmos $\$ 4.116$ de imposto pagos pela sistemática de tributação pelo lucro.

Para a elaboração do mesmo exemplo com inflação, foram feitas as seguintes considerações:

- Os eventos e os valores do exemplo sem inflação continuam os mesmos, à exceção do IR/CS, que será recalculado conforme as perdas inflacionárias no caixa;

- Os eventos ocorrem no final de cada período;

- Os índices de inflação utilizados são os seguintes:

Tabela 4.27 - Índices de Inflação Considerados

\begin{tabular}{ll}
\hline Período 0 & $\mathbf{2 , 0 0}$ \\
Período 1 & $\mathbf{2 , 2 0}$ \\
Período 2 & $\mathbf{2 , 4 2}$ \\
Período 3 & $\mathbf{2 , 6 6}$ \\
Período 4 & $\mathbf{2 , 9 3}$ \\
\hline
\end{tabular}

Com isso, foi refeita a movimentação de caixa período a período, para a identificação dos saldos finais de caixa, já levando em conta o pagamento de IR/CS calculado com a inflação, que será demonstrado adiante: 
Tabela 4.28 - Movimentação de Caixa Sem Inflação com Impostos Apurados com

\begin{tabular}{lcccccc} 
& \multicolumn{7}{c}{ Correção } & \multicolumn{2}{c}{} & \multicolumn{1}{c}{} \\
\cline { 2 - 7 } & $\mathbf{0}$ & $\mathbf{1}$ & $\mathbf{2}$ & $\mathbf{3}$ & $\mathbf{4}$ & Total \\
Saldo Inicial & - & $\mathbf{5 . 0 0 0}$ & $\mathbf{5 5 0}$ & $\mathbf{1 1 . 1 5 0}$ & $\mathbf{2 6 . 3 6 0}$ & \\
1Recebimento Vendas & - & - & 15.000 & 15.000 & - & 30.000 \\
Recebimento Juros & & & & 210 & & 210 \\
Pagamento Fornec. & - & $(2.500)$ & $(2.500)$ & - & - & $(5.000)$ \\
Pagto. Desp. Adm. & - & $(800)$ & $(800)$ & - & - & $(1.600)$ \\
Pagto. IR / CS & - & - & - & - & $(3.797)$ & $(3.797)$ \\
Pagto de Juros & - & $(150)$ & $(100)$ & - & - & $(250)$ \\
Aplic.Financ. /Resg. & $(1.000)$ & & & 1.000 & & - \\
Aquis. Imobilizado & $(6.000)$ & - & - & - & - & $(6.000)$ \\
& & & & & & - \\
Empréstimos & 3.000 & $(1.000)$ & $(1.000)$ & $(1.000)$ & - & - \\
Capital & 9.000 & - & - & - & - & 9.000 \\
Saldo Final & $\mathbf{5 . 0 0 0}$ & $\mathbf{5 5 0}$ & $\mathbf{1 1 . 1 5 0}$ & $\mathbf{2 6 . 3 6 0}$ & $\mathbf{2 2 . 5 6 3}$ & \\
\hline
\end{tabular}

A partir dessa movimentação, é possível apurar os ganhos e perdas inflacionárias com os itens monetários. Para isso, é necessário refazer a movimentação em moeda constante, inclusive o próprio IR/CS pago no período, para apurar o Saldo que Deveria Existir (SQDE) e compará-la ao saldo existente (o saldo final do quadro anterior). A seguinte demonstração da apuração das perdas inflacionárias no caixa já está toda em moeda do final do período 4:

\begin{tabular}{lcccccc}
\multicolumn{7}{c}{ Tabela 4.29 - Apuração das Perdas Inflacionárias no Caixa } \\
& $\mathbf{0}$ & $\mathbf{1}$ & $\mathbf{2}$ & $\mathbf{3}$ & $\mathbf{4}$ & TOTAL \\
\cline { 2 - 7 } Saldo Inicial & - & $\mathbf{7 . 3 2 1}$ & $\mathbf{7 3 2}$ & $\mathbf{1 3 . 4 9 2}$ & $\mathbf{2 8 . 9 9 6}$ & \\
Recebimento Vendas & - & - & 18.150 & 16.500 & - & 34.650 \\
Recebimento Juros & & & & 231 & & 231 \\
Pagamento Fornec. & - & $(3.328)$ & $(3.025)$ & - & - & $(6.353)$ \\
Pagto. Desp. Adm. & - & $(1.065)$ & $(968)$ & - & - & $(2.033)$ \\
Pagto. IR / CS & - & - & - & - & $(3.797)$ & $(3.797)$ \\
Pagto de Juros & - & $(200)$ & $(121)$ & - & - & $(321)$ \\
Aplic.Financ. /Resg. & $(1.464)$ & & & 1.100 & & $(364)$ \\
Aquis. Imobilizado & $(8.785)$ & - & - & - & - & $(8.785)$ \\
Empréstimos & 4.392 & $(1.331)$ & $(1.210)$ & $(1.100)$ & - & 751 \\
Capital & 13.177 & - & - & - & - & 13.177 \\
SQDE & $\mathbf{7 . 3 2 1}$ & $\mathbf{1 . 3 9 8}$ & $\mathbf{1 3 . 5 5 8}$ & $\mathbf{3 0 . 2 2 3}$ & $\mathbf{2 5 . 1 9 9}$ & \\
SE & $\mathbf{7 . 3 2 1}$ & $\mathbf{7 3 2}$ & $\mathbf{1 3 . 4 9 2}$ & $\mathbf{2 8 . 9 9 6}$ & $\mathbf{2 2 . 5 6 3}$ & \\
Perda no Caixa & - & $\mathbf{( 6 6 6 )}$ & $\mathbf{( 6 7 )}$ & $\mathbf{( 1 . 2 2 7 )}$ & $\mathbf{( 2 . 6 3 6 )}$ & \\
\hline
\end{tabular}


Essas perdas no Caixa foram consideradas na base de cálculo dos tributos, período a período.

Do mesmo modo, foram apurados os ganhos inflacionários com empréstimos, que abaixo já estão em moeda de final do período 4:

Tabela 4.30 - Apuração dos Ganhos e Perdas Inflacionários nos Empréstimos

Saldo Inicial

Obtenção Empréstim.

Despesa Financeira

Pgto. de Juros

Amortiz. Empréstim.

SQDE

SE

Ganho/Perda

\begin{tabular}{cccccc}
\multicolumn{1}{c}{} & $\mathbf{1}$ & $\mathbf{2}$ & $\mathbf{3}$ & $\mathbf{4}$ & TOTAL \\
\hline- & 4.392 & 2.662 & 1.210 & \\
4.392 & & & & 4.392 \\
& 200 & 121 & & \\
& $(200)$ & $(121)$ & & \\
& $(1.331)$ & $(1.210)$ & $(1.100)$ & $(3.641)$ \\
\hline 4.392 & 3.061 & 1.452 & 110 & \\
4.392 & 2.662 & 1.210 & - & $\mathbf{7 5 1}$
\end{tabular}

Com esses ganhos e perdas inflacionários, é possível apurar o imposto devido. Período a período, foi-se apurando o fluxo de caixa tributável. Sobre isso, foram feitos os ajustes dos ganhos com empréstimos e dos valores dos impostos pagos no período.

A tabela a seguir mostra a apuração do IR/CS a pagar e a compensar em cada um dos períodos, a partir dos fluxos de caixa tributáveis ajustados pelos ganhos e perdas com itens monetários das atividades de financiamento e pelo IR/CS pago no período: 
Tabela 4.31 - Apuração de IR/CS por Fluxo de Caixa Com Inflação

\begin{tabular}{|c|c|c|c|c|c|c|}
\hline & 0 & 1 & 2 & 3 & 4 & TOTAL \\
\hline \multicolumn{7}{|l|}{ Fluxo Caixa Tribut. } \\
\hline Recebimento Vendas & - & - & 18.150 & 16.500 & - & 34.650 \\
\hline Recebimento Juros & - & - & - & 231 & - & 231 \\
\hline Pagamento Fornec. & - & (3.328) & $(3.025)$ & - & - & $(6.353)$ \\
\hline Pagto. Desp. Adm. & - & (1.065) & (968) & - & - & (2.033) \\
\hline Pagto. IR / CS & - & - & - & - & (3.797) & (3.797) \\
\hline Pagto de Juros & - & (200) & $(121)$ & - & - & (321) \\
\hline Perdas Caixa & - & (666) & $(67)$ & $(1.227)$ & $(2.636)$ & $(4.595)$ \\
\hline Aplic.Financ. /Resg. & $(1.464)$ & - & - & 1.100 & - & (364) \\
\hline \multirow{2}{*}{ Aquis. Imobilizado } & $(8.785)$ & - & - & - & - & $(8.785)$ \\
\hline & $(10.249)$ & $(5.257)$ & 13.969 & 16.605 & $(6.433)$ & 8.635 \\
\hline \multicolumn{7}{|l|}{ Ajustes } \\
\hline G/P Empréstimos & - & 399 & 242 & 110 & - & 751 \\
\hline IR/CS Pagos & & & & - & 3.797 & 3.797 \\
\hline FI.Caixa Tribut.Aj. & $(10.249)$ & $(4.858)$ & 14.211 & 16.715 & $(2.636)$ & 13.183 \\
\hline IR/CS Devido & $(2.460)$ & (1.166) & 3.411 & 4.011 & (633) & 3.164 \\
\hline IR/CS a Compensar & 2.460 & 3.626 & 215 & - & 633 & - \\
\hline IR/CS a Pagar & - & - & - & 3.797 & - & - \\
\hline \multicolumn{7}{|l|}{ FI.Caixa Não Tribut. } \\
\hline Empréstimos & 4.392 & (1.331) & $(1.210)$ & $(1.100)$ & - & 751 \\
\hline \multirow[t]{2}{*}{ Capital } & 13.177 & - & - & - & - & 13.177 \\
\hline & 17.569 & (1.331) & $(1.210)$ & $(1.100)$ & - & 13.928 \\
\hline Saldo Inicial & - & 7.321 & 732 & 13.492 & 28.996 & \\
\hline Saldo Final & 7.321 & 732 & 13.492 & 28.996 & 22.563 & \\
\hline
\end{tabular}

Apesar de os ganhos inflacionários com empréstimos representarem reduções das despesas financeiras, eles não constituem recebimentos efetivos, mas são observados pela diferença no valor do empréstimo pago. Assim, eles não foram classificados dentro dos fluxos de caixa tributáveis, mas como ajustes, uma vez que isso torna conciliável o total dos fluxos tributáveis e não tributáveis com a variação efetiva de caixa. Para simplificar, poder-se-ia considerar como dedutíveis apenas os juros reais pagos.

Percebe-se que foi considerado também um item monetário da atividade de investimento: uma aplicação financeira. Não foi necessária a apuração dos 
ganhos ou perdas com essa aplicação, uma vez que eles já estão embutidos nos recebimentos de juros e na diferença entre o valor da aplicação e do seu resgate. Isso acontece porque toda sua movimentação está considerada dentro dos fluxos tributáveis, ao contrário dos itens monetários dos fluxos de financiamento.

Como se pode verificar na DRE a seguir em correção integral, elaborada com a consideração de todos os ganhos e perdas nos itens monetários, os recebimentos de juros mais a diferença entre aplicação e resgate na DFC (231 $+-364=-133)$ é igual à Receita Financeira mais os Ganhos e Perdas com Aplicações Financeiras da DRE $(266+-399=-133)$ :

Tabela 4.32 - DRE dos Cinco Períodos em CMI

\begin{tabular}{lcccccc} 
DRE & $\mathbf{0}$ & $\mathbf{1}$ & $\mathbf{2}$ & $\mathbf{3}$ & $\mathbf{4}$ & TOTAL \\
\hline Receita de Vendas & & 19.965 & 18.150 & & & 38.115 \\
Custos & & $(5.856)$ & $(5.524)$ & & & $(11.380)$ \\
Despesas Administr. & & $(1.065)$ & $(968)$ & & & $(2.033)$ \\
Receitas Financeiras & & 133 & 133 & & & 266 \\
Despesas Financ. & & $(200)$ & $(121)$ & & & $(321)$ \\
Perdas Caixa & - & $(666)$ & $(67)$ & $(1.227)$ & $(2.636)$ & $(4.595)$ \\
G/P Aplic. Fin. & - & $(133)$ & $(133)$ & $(133)$ & - & $(399)$ \\
G/P C. Receber & - & - & $(1.815)$ & $(1.650)$ & - & $(3.465)$ \\
G/P Fornecedores & - & 333 & 303 & - & - & 635 \\
G/P Empréstimos & - & 399 & 242 & 110 & - & 751 \\
Despesas Deprec. & & $(2.196)$ & $(2.196)$ & & & $(4.392)$ \\
LAIR/CS & & 10.715 & 8.004 & $(2.900)$ & $(2.636)$ & 13.183 \\
IR/CS 15\% + 9\% & & $(2.571)$ & $(1.921)$ & 696 & 633 & $(3.164)$ \\
Lucro Líquido & & $\mathbf{8 . 1 4 3}$ & $\mathbf{6 . 0 8 3}$ & $\mathbf{( 2 . 2 0 4 )}$ & $\mathbf{( 2 . 0 0 3 )}$ & $\mathbf{1 0 . 0 1 9}$ \\
\hline
\end{tabular}

Resumindo, para se calcular o IR/CS devido considerando a inflação, é necessário levantar as perdas inflacionárias no caixa e os ganhos ou perdas nos itens monetários que resultam no fluxo de caixa de financiamento. Os ganhos ou perdas nos demais itens monetários já estão considerados dentro da movimentação contida nos fluxos tributáveis. 


\section{IMPLICAÇÕES DO MODELO}

\subsection{INTRODUÇÃO}

Neste capítulo, vamos discutir quatro pontos fundamentais para a análise do modelo de tributação por fluxos de caixa proposto no capítulo anterior: suas implicações sobre a capacidade de pagamento do contribuinte, sobre os princípios contábeis, sobre os custos de conformidade, tanto do lado do contribuinte como do lado do governo, e sobre a arrecadação.

\subsection{CAPACIDADE CONTRIBUTIVA}

\subsubsection{Conceito de Capacidade Contributiva}

Segundo Rezende ${ }^{61}$, a teoria da tributação está baseada em dois princípios fundamentais: Neutralidade e Equidade.

O princípio da Neutralidade refere-se à não-interferência do sistema tributário sobre as decisões de alocação de recursos tomadas com base no mecanismo de mercado, uma vez que essa interferência implica em redução no nível geral de bem-estar que poderia ser atingido com os recursos disponíveis.

\footnotetext{
${ }^{61}$ REZENDE, Fernando. Finanças públicas, p.158.
} 
Além de o imposto ser neutro, o imposto ideal deveria ainda ser justo, no sentido de garantir uma distribuição eqüitativa do ônus tributário pelos indivíduos. Essa eqüidade poderia ser vista sob duas ópticas: o ônus poderia ser atribuído a cada indivíduo de acordo com o benefício que ele usufrui dos programas governamentais ou em função das respectivas capacidades individuais de contribuição.

O princípio da Neutralidade diz respeito à seleção do tipo de tributo de acordo com o seu efeito sobre a alocação de recursos. Rezende ${ }^{62}$ demonstra que há argumentos que contestam a superioridade dos impostos sobre a renda em relação aos impostos sobre consumo, mas essa discussão não faz parte deste trabalho, uma vez que tomamos como dada a existência de tributação sobre a renda.

Assim, o princípio em questão é o da Equidade e seus dois critérios: o do benefício e o da capacidade de contribuição. 0 critério do benefício, como o próprio Rezende ${ }^{63}$ argumenta, tem restrições de ordem prática à sua aplicação, sendo principal a dificuldade de se quantificar os benefícios que cada indivíduo atribui ao consumo de diferentes quantidades de bens públicos, o que torna praticamente impossível a aplicação de tal critério.

Desse modo, a discussão recai sobre o critério da capacidade de contribuição.

\footnotetext{
${ }^{62}$ REZENDE, Fernando. Finanças públicas, p.159-62.

${ }^{63}$ REZENDE, Fernando. Finanças públicas, p.163-4.
} 
Conti $^{64}$ vê a capacidade contributiva de dois ângulos: o estrutural e o funcional. Pelo estrutural, a capacidade contributiva é a aptidão de arcar com a despesa de determinado tributo. Pelo funcional, a capacidade contributiva é um critério destinado a diferenciar as pessoas, a identificar quem são os desiguais e em que medida e montante se desigualam.

Em outras palavras, a capacidade contributiva pode ser vista sob dois aspectos: quem pode pagar mais, proporcionalmente, tem maior capacidade contributiva; não a possui aquele que não tem condições de efetuar 0 pagamento do tributo. Isso nos remete aos conceitos de progressividade e capacidade econômica.

Tem esta última qualquer indivíduo que disponha de alguma riqueza ou de aptidão para obtê-la. Essa diferenciação tem uma razão: um indivíduo pode ter capacidade econômica, mas não capacidade contributiva, como é o caso de um cidadão rico, apenas de passagem pelo país. Seus rendimentos são suficientes para pagar tributos, mas não há nenhuma relação jurídica que o vincule ao Fisco do país pela qual transita. Do mesmo modo, um sujeito pode possuir renda que lhe permita somente um mínimo vital, que é intributável. Ele é capaz economicamente, mas não tem capacidade contributiva.

64 CONTI, José M. Princípios tributários da capacidade contributiva e da progressividade, p. 33-7. 


\subsubsection{A Capacidade Financeira}

Ainda em relação à capacidade contributiva, Conti ${ }^{65}$ também discute um outro aspecto além da capacidade econômica (e para nós bastante importante), que é a capacidade financeira:

"Há ainda a menção à expressão 'capacidade financeira', que pode ser encontrada em Agostinho Toffoli Tavolaro. Entende ele como sendo capacidade financeira a disponibilidade para liquidação de suas obrigações no tempo e forma contratados. Nota-se, assim, ser conceito voltado para o aspecto da liquidez".

O referido autor considera que a capacidade financeira, ligada ao aspecto da liquidez, é mais um ângulo da capacidade contributiva.

Assim, podemos dizer que têm capacidade contributiva aqueles que são capazes econômica e financeiramente em nível suficiente para serem tributados, na medida de suas desigualdades, e que estão sob a abrangência da hipótese de incidência prevista em lei.

Para reforçar o entendimento de capacidade financeira e para diferenciála de capacidade econômica, Conti $^{66}$ dá um exemplo:

"A distinção entre capacidade econômica e capacidade financeira também pode ser esclarecida por meio de um exemplo. Supor determinado contribuinte, proprietário de um imóvel de alto valor que, por qualquer razão, encontre-se em dificuldades materiais. O Município estabelece um valor legítimo

65 CONTI, José M. Princípios tributários da capacidade contributiva e da progressividade, p. 35.

66 CONTI, José M. Princípios tributários da capacidade contributiva e da progressividade, $\mathrm{p} .36$. 
para a cobrança do IPTU. O contribuinte, no entanto, não tem como dispor de recursos para arcar com o tributo. Neste caso, o que vemos é um indivíduo que tem capacidade contributiva, sendo sujeito passivo de uma imposição tributária legítima haja vista ser proprietário de um bem valioso, que é indicador de riqueza -, e também capacidade econômica, pois, como já mencionado, dispõe de riqueza sob a forma de um imóvel de alto valor. Não tem, no entanto, capacidade financeira, dada a falta absoluta de liquidez para obter recursos com a finalidade de pagar o tributo que deve".

Entretanto, ele exemplifica a questão com uma situação que é a falta de disponibilidade diante da obrigação de pagar um tributo cuja base de incidência é o seu patrimônio.

A capacidade financeira também abrange a tributação sobre a renda e, em particular, o lucro das empresas, foco de nosso estudo. É possível que uma empresa tenha capacidade econômica para ser tributada, ou seja, tenha auferido lucro durante um período, mas ainda não tenha capacidade financeira no momento do vencimento do tributo.

Em parte, isso pode ser explicado pelo fato de que o vencimento pode ocorrer antes do prazo médio de recebimento de vendas. É o que mostramos no Capítulo 1, conforme quadro abaixo, reproduzido apenas para nova ilustração, elaborado a partir do prazo médio de recebimento de vendas de empresas brasileiras e do prazo de vencimento atual do IR:

Figura 5.1 - Prazos com IR Anual e Pagamento por Estimativa

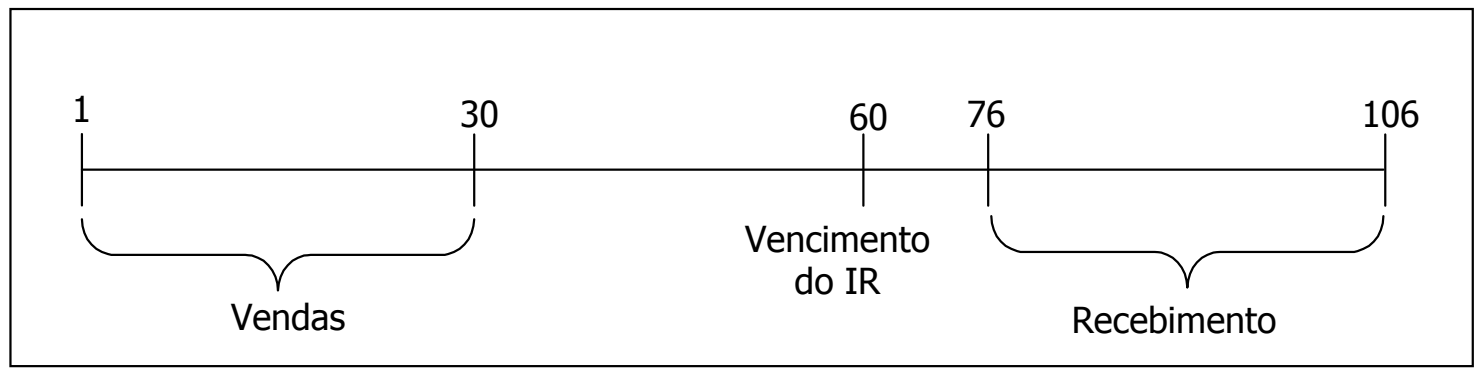


Assim, o imposto é pago, em média, antes que a receita de vendas que gerou o lucro base do mesmo tributo tenha sido recebida. Com isso, não há entradas de caixa dessas operações para dar suporte a um pagamento que só será efetuado porque há lucro.

É óbvio que, se a empresa acaba pagando o tributo na data de vencimento, o dinheiro tem outra origem que não a própria operação que gerou a dívida tributária, que pode ser:

1. saldo anterior de caixa;

2. redução de outros ativos;

3. financiamento com capital de terceiros;

4. financiamento com capital próprio.

Uma quinta alternativa seria atrasar o pagamento dos tributos. Essa alternativa tem sido utilizada pelas empresas brasileiras, como mostra a seguinte tabela:

Tabela 5.1 - Valores da União em Cobrança

\begin{tabular}{|l|c|c|}
\hline \multicolumn{3}{|c|}{ Valores em R\$ Milhões } \\
\hline $\begin{array}{l}\text { Arrecadação da Receita Administrada pela } \\
\text { SRF em 2002 }\end{array}$ & 243.005 & - \\
\hline $\begin{array}{l}\text { Total de Passivos Tributários em Cobrança na } \\
\text { SRF em 31/12/2002 }\end{array}$ & 334.995 & $64,9 \%$ \\
\hline $\begin{array}{l}\text { Estoque da Dívida Ativa da União em } \\
\text { Cobrança na Procuradoria-Geral da Fazenda } \\
\text { Nacional em 31/12/2002 }\end{array}$ & 180.993 & $35,1 \%$ \\
\hline Total em Cobrança da União em 31/12/2002 & 515.988 & $100,0 \%$ \\
\hline Total em Cobrança / Arrecadação da SRF & 2,12 & - \\
\hline
\end{tabular}

Entretanto, o atraso no pagamento também tem um custo. Apenas para ilustrar, atualmente os tributos federais têm multa de $0,33 \%$ ao dia até o limite de $20 \%$. No mês seguinte ao vencimento, é acrescido $1 \%$ de juros. Do terceiro 
mês em diante, é acrescida a taxa Selic (Sistema Especial de Liquidação e Custódia) divulgada pelo COPOM (Comitê de Política Monetária) do Banco Central.

Além disso, há outros custos implícitos além das multas e dos juros. 0 débito tributário impede a emissão de Certidão Negativa de Débito, o que dificulta a tomada de crédito e impede a participação em licitações e alterações societárias. Além disso, pode haver penhora do faturamento pela Procuradoria da Fazenda. O custo do passivo tributário só é zero enquanto se está dentro do vencimento.

Voltando às quatro primeiras alternativas, o saldo anterior de caixa pode ter provindo das próprias operações ou das demais alternativas acima.

O saldo de caixa advindo das operações existe apenas na hipótese de que tenha havido geração operacional positiva de caixa anteriormente. Entretanto, mesmo que a empresa esteja em marcha e tenha gerado caixa operacional no período decorrente de lucros passados, presentes ou futuros, a empresa pode não ter dinheiro no momento do vencimento do tributo.

Na verdade, essa é uma questão de manter ou não saldo em caixa, porque se ela não tem dinheiro, mesmo tendo lucro e geração de caixa, é porque ela investiu em alguma coisa ou devolveu capital a terceiros ou aos proprietários. 
Keynes $^{67}$ aponta três motivos que explicam a manutenção de recursos em caixa:

- O motivo-transação, que pode ser separado em dois - o motivo-renda e os motivos-negócios. O primeiro está relacionado à manutenção de disponibilidade entre o momento do recebimento dos lucros e o seu desembolso. O segundo, ligado à operação, decorre da necessidade de assegurar o intervalo do ciclo de caixa;

- O motivo-precaução, que decorre da possível necessidade de atender às contingências inesperadas e às oportunidades imprevistas de realizar compras vantajosas e os de conservar um ativo fixo no pagamento de uma obrigação;

- O motivo-especulação, que está relacionado com as variações na taxa de juros, decorrentes das variações no preço dos títulos e das dívidas de vencimentos diversos.

Considerando que o pagamento do IR é decorrente das operações, a empresa até teria motivos e condições para efetuá-lo, mas incentivos decorrentes de oportunidades ou taxas de juros podem levá-la a efetuar desembolsos em outras aplicações.

Assim, ter lucro e geração de caixa operacional não garante que a empresa irá efetivamente pagar seus tributos, mas certamente ela tem capacidade econômica e financeira para fazê-lo.

\footnotetext{
${ }^{67}$ KEYNES, John M. A teoria geral do emprego, do juro e da moeda, p. 157-9.
} 
Se a empresa teve lucro, mas não geração de caixa operacional no período, o recurso necessário para se efetuar o pagamento do tributo também deve vir das mesmas quatro fontes apontadas anteriormente.

Na verdade, essas fontes são três: as próprias operações, o capital de terceiros e o capital próprio. O saldo anterior de caixa pode ter sido formado pela composição dessas três fontes, assim como os ativos adquiridos que podem sofrer redução.

Resta saber, dessas três, qual é a fonte mais adequada. Das formas de financiamento em geral, a preferida pelas empresas é a dos lucros acumulados, como mostra Damodaran ${ }^{68}$ :

Tabela 5.2 - Formas Preferidas de Financiamento em Geral

\begin{tabular}{|l|l|l|l|}
\hline Classificação & \multicolumn{1}{|c|}{ Fontes } & $\begin{array}{c}\text { Linha de Planejamento } \\
\text { Financeiro Citado }\end{array}$ & Pontuação \\
\hline 1 & Lucros Acumulados & Nenhum & 5,61 \\
\hline 2 & Dívida Pura & Maximizar o Preço das Ações & 4,88 \\
\hline 3 & Dívida Conversível & Fluxo de Caixa e Sobrevivência & 3,02 \\
\hline 4 & Patrimônio Líquido Externo & Evitar Diluição Acionária & 3,42 \\
\hline 5 & Ações Preferenciais & Comparação & 2,22 \\
\hline 6 & Conversíveis Preferenciais & Nenhum & 1,72 \\
\hline
\end{tabular}

De acordo com o mesmo autor ${ }^{69}$, as demais fontes de capital reduzem a flexibilidade para futuros financiamentos e reduzem o controle (em função de cláusulas dos títulos e a possibilidade de redução da participação percentual dos controladores). Além disso, os lucros acumulados custam menos que endividamento externo e menos ainda que capital próprio externo.

\footnotetext{
${ }^{68}$ DAMODARAN, Aswath. Finanças corporativas aplicadas, p. 265.

${ }^{69}$ DAMODARAN, Aswath. Finanças corporativas aplicadas, p. 264-6.
} 
Se os lucros acumulados são a fonte preferencial de financiamento, é natural que os recursos para o pagamento dos tributos sejam provenientes dessa fonte, devendo estar compondo o saldo de caixa ou estarem investidos em outros ativos.

O problema é que voltamos ao problema inicial, porque ter lucro não significa necessariamente ter capacidade financeira.

Embora lucro e geração de caixa das operações mais investimento sejam correspondentes, como visto anteriormente, o que está mais próximo da capacidade financeira é a geração de caixa, porque ocorrem em tempos diferentes.

Na prática, dificilmente o lucro de um período corresponde à geração de caixa do mesmo período, em função dos prazos de recebimento e pagamento. Isso provoca diferenças entre os montantes de lucro e geração de caixa em um mesmo período.

Essas diferenças podem ser observadas em uma Demonstração dos Fluxos de Caixa, segundo as normas do FASB (e também do IASB), elaborado pelo método indireto. Ela tem, nos fluxos operacionais, uma conciliação entre o lucro líquido e a geração de caixa operacional, que mostra justamente o quanto do lucro se transformou em caixa das operações, por meio de ajustes ao lucro líquido de itens que não afetam o caixa no período e das variações em ativos e passivos operacionais. 
A seguir, apresentamos um exemplo de uma DFC pelo método indireto, da empresa Embraer Empresa Brasileira de Aeronáutica S/A, retirado de seu relatório anual ${ }^{70}$ de 2.000 :

Tabela 5.3 - Demonstração do Fluxo de Caixa - Embraer S/A

\begin{tabular}{|lcc|}
\hline & \multicolumn{2}{c|}{ Consolidado } \\
FLUXO DE CAIXA & $\mathbf{1 9 9 9}$ & $\mathbf{2 0 0 0}$ \\
& & \\
Atividades Operacionais & & \\
Lucro Líquido do Exercício & 412.152 & 645.179 \\
Itens que não Afetam o caixa & & \\
Depreciações e amortizações & 127.495 & 150.156 \\
Provisão para Devedores Duvidosos & 17.690 & 8.408 \\
Ganhos (Perdas) na Alienação AP & 1.495 & 1.767 \\
Baixa do Diferido & 31.288 & 1.182 \\
Reversão de Resultado Ex. Futuros & $(817)$ & $(12)$ \\
Provisão para Perdas & 7.297 & 14.058 \\
IR e CS Diferidos & $(162.966)$ & $(67.275)$ \\
Juros s/ parc.impostos, deb., financ. e outros & 87.436 & 80.760 \\
Provisão (Reversão) contingências & 6.492 & $(107)$ \\
Variações Cambiais Líquidas & 308.462 & 76.194 \\
Ganho na conversão dos invest. Controladas & - & - \\
Participação dos minoritários & - & 5.299 \\
Baixa de investimentos & - & 46 \\
Ganho na participação acionária & - & - \\
Equivalência patrimonial & 254 & $(1.472)$ \\
& $\mathbf{9 1 4 . 1 8 3}$ \\
Mudanças nos Ativos e Passivos Circulantes & $\mathbf{8 3 6 . 2 7 8}$ & \\
Contas a Receber & $(405.320)$ & 214.934 \\
Estoques & $(598.784)$ & 159.496 \\
Despesas pagas antecipadamente & $(291)$ & $(8.193)$ \\
Impostos diferidos e a recuperar & $(9.795)$ & 21.306 \\
Outras contas a receber & $(15.740)$ & $(245)$ \\
Fornecedores & 109.246 & 162.948 \\
Impostos a recolher & 47.984 & 51.877 \\
Provisões diversas & 59.027 & 237.578 \\
Adiantamentos de clientes & 215.544 & 176.636 \\
IR e CS a recolher & 23.514 & 112.799 \\
Outros & 16.398 & 72.597 \\
Mudanças nos Ativos e Passivos de Longo Prazo & $\mathbf{( 5 5 8 . 2 1 7 )}$ & $\mathbf{1 . 2 0 1 . 7 3 3}$ \\
Contas a Receber & $(3.076)$ & $(17.631)$ \\
Impostos a Recuperar & $(7.720)$ & $(1.083)$ \\
\hline
\end{tabular}

${ }^{70}$ Disponível em www.embraer.com. 


\begin{tabular}{|c|c|c|}
\hline Outras contas a receber & 22.202 & 20.781 \\
\hline Fornecedores & $(4.509)$ & - \\
\hline Contas a Pagar & 24.856 & 242.001 \\
\hline Adiantamentos de clientes & 83.823 & $(42.743)$ \\
\hline Resultado de exercícios futuros & - & $(1)$ \\
\hline Provisões diversas & $(15.882)$ & $(10.096)$ \\
\hline Impostos a recolher & - & $(35.920)$ \\
\hline \multirow[t]{2}{*}{ Participação minoritária } & - & 10.690 \\
\hline & 99.694 & 165.998 \\
\hline Caixa Gerado pelas Atividades Operacionais & 377.755 & 2.281.914 \\
\hline \multicolumn{3}{|l|}{ Atividades de Investimento } \\
\hline Venda de imobilizado & 279 & 1.859 \\
\hline Depósitos e empréstimos compulsórios & 285 & $(4.134)$ \\
\hline Adições ao imobilizado & $(87.114)$ & $(195.953)$ \\
\hline Adições ao diferido & $(25.560)$ & $(105.008)$ \\
\hline Adições ao investimento & $(19)$ & 4.160 \\
\hline Redução de capital de controlada & - & - \\
\hline Caixa Usado nas Atividades de Investimento & $(112.129)$ & $(299.076)$ \\
\hline \multicolumn{3}{|l|}{ Atividades Financeiras } \\
\hline Resgate de ações classe "B" & $(9.549)$ & - \\
\hline Financiamentos pagos & $(1.709 .106)$ & $(2.087 .260)$ \\
\hline Novos financiamentos obtidos & 1.625 .782 & 1.689 .807 \\
\hline Pagamento de parcelamentos de impostos & $(5.314)$ & (5.698) \\
\hline Depósitos em garantia & $(23.556)$ & $(13.728)$ \\
\hline Dividendos pagos & $(70.887)$ & $(224.629)$ \\
\hline Pagamento de encargos sobre debêntures & $(3.436)$ & $(3.730)$ \\
\hline Emissão de debêntures & 164.507 & - \\
\hline Aumento de capital & - & 439.824 \\
\hline Caixa Usado nas Atividades Financeiras & $(31.359)$ & $(205.414)$ \\
\hline Aumento Líquido do Disponível & 234.267 & 1.777 .424 \\
\hline Disponível no Início do Exercício & 313.888 & 548.155 \\
\hline Disponível no Final do Exercício & 548.155 & 2.325 .579 \\
\hline
\end{tabular}

É possível verificar que o Lucro Líquido de 2.000 , de $\$ 645$ milhões, com seus ajustes de itens que não afetam o caixa, gerou $\$ 914$ milhões. Esses ajustes se referem a resultados que não têm efeito caixa no período de 2.000, mas que já tiveram impacto (como é o caso das depreciações e amortizações) ou terão impacto no futuro (no caso de IR e CS diferidos). No total, houve uma 
geração operacional de $\$ 2.282$ milhões, proporcionada principalmente por reduções líquidas no Ativo Circulante e aumentos líquidos no Passivo Circulante, da ordem de $\$ 1.202$ milhões.

Em suma, a empresa tem capacidade contributiva quando tem lucro (capacidade econômica) e disponibilidade (capacidade financeira) para o pagamento do tributo, sendo que a geração operacional de caixa é a fonte natural dessa disponibilidade, porque as demais fontes reduzem a capacidade econômica, em função dos custos financeiros envolvidos, mesmo que de oportunidade.

\subsubsection{Implicações do Modelo sobre a Capacidade Contributiva}

O imposto de renda sobre o lucro das empresas é considerado por muitos como uma forma de tributação que atende ao critério da capacidade contributiva, uma vez que o lucro representa a renda dos proprietários, o que significa aumento do seu patrimônio. Assim, o lucro demonstra capacidade econômica, podendo ser tributado.

Entretanto, em relação ao aspecto da capacidade financeira, não necessariamente a empresa a tem, mesmo tendo lucro, como visto anteriormente. Ela só terá se houver geração operacional de caixa, financiamento de terceiros ou de capital próprio.

Vamos agora contrapor o modelo de tributação por lucro ao modelo de tributação por fluxos de caixa. 
O modelo proposto no capítulo anterior está baseado na tributação do somatório da geração/consumo de caixa operacional e da geração/consumo de caixa de investimentos. Esse somatório, com seus ajustes, é o fluxo de caixa tributável. Esse modelo foi desenvolvido com base na sua correspondência com o lucro, conforme discutido no capítulo 2 .

A questão que se coloca agora é a seguinte: pelo modelo de tributação por fluxos de caixa, a empresa tem capacidade econômica e financeira? 0 motivo dessa questão está relacionado ao fato de que o fluxo de caixa de um período dificilmente corresponde ao lucro do mesmo período.

A capacidade econômica está ligada à existência de riqueza ou aptidão para obtê-la. No caso do imposto de renda, a tributação ocorre sobre a renda dos proprietários, o que significa que a capacidade econômica está ligada ao aumento da riqueza, medida pelo lucro. Assim, a geração caixa operacional mais investimentos não é uma medida de capacidade econômica, muito embora seja correspondente ao lucro. Ela é, sim, uma medida de capacidade financeira.

A empresa pode ter capacidade econômica em um determinado momento, mas não financeira, e vice-versa. Podemos separar essa questão em quatro situações, colocadas na seguinte tabela:

Tabela 5.4 - Capacidade Econômica e Financeira

\begin{tabular}{|c|c|c|}
\hline & $\begin{array}{c}\text { Geração } \\
\text { de Caixa }\end{array}$ & $\begin{array}{c}\text { Consumo } \\
\text { de Caixa }\end{array}$ \\
\hline Lucro & $\begin{array}{c}\text { Cap. Econômica } \\
\text { Cap. Financeira }\end{array}$ & Cap. Econômica \\
\hline Prejuízo & Cap. Financeira & - o - \\
\hline
\end{tabular}

Embora não se possa dizer que o modelo baseado em caixa não represente capacidade econômica, comparando com o modelo baseado no lucro 
é possível dizer que a empresa pode ter maior capacidade econômica, porque com esse modelo ela pode ter menor necessidade de incorrer em custos financeiros em função da redução do descompasso entre lucro e geração de caixa.

Se o lucro é a forma preferida de financiamento por parte das empresas, principalmente porque é a mais barata, a geração de caixa aumenta a possibilidade de se financiar dessa forma.

A empresa pode até utilizar o recurso da geração de caixa em outra aplicação, mas ela já teve em algum momento a disponibilidade em caixa.

Assim, a tributação por fluxos de caixa proporciona maior capacidade econômica e maior capacidade financeira, o que, juntos, representam maior capacidade contributiva.

\subsection{PRINCÍPIOS CONTÁBEIS}

\subsubsection{A INTERfERÊNCIA dAS NoRMAS TributáRIAS SOBRE OS PCGA}

Como visto no Capítulo 1, a tributação do lucro tem provocado, não só no Brasil, mas em diversos países, a interferência sobre a forma de contabilização dos eventos, basicamente porque o fisco sente a necessidade de definir o lucro tributável de forma diferente do lucro contábil. 
Essa necessidade deriva principalmente da crença de que o contribuinte pode se utilizar de artifícios para manipular os resultados contábeis e reduzir o valor do tributo a pagar no período.

De fato, se o contribuinte estiver mal intencionado, ele pode, por exemplo, criar provisões, com medidas subjetivas, reduzindo o lucro e ficando por prazo indeterminado no passivo, sem que jamais efetivamente passe pelo caixa.

Uma outra forma, que apenas posterga o pagamento do imposto, é reduzir, "no papel", a vida útil de um bem do imobilizado, aumentando o valor da despesa de depreciação dos primeiros períodos e reduzindo o lucro tributável.

Assim, para evitar a sonegação ou a postergação do imposto a pagar, o fisco estabelece regras próprias de reconhecimento e mensuração do lucro tributável.

Além desses objetivos, o fisco também edita normas que têm por objetivo atender a políticas econômicas e facilitar procedimentos fiscais. No primeiro caso, se enquadram a proibição do não reconhecimento dos resultados inflacionários e a instituição dos juros sobre capital próprio. No segundo caso, pode-se classificar a definição do ano-calendário como período de tributação, independentemente do ciclo operacional da empresa.

Mesmo que haja a possibilidade de se fazer a contabilização correta, de acordo com os princípios contábeis geralmente aceitos (PCGA), e posteriormente ajustar o lucro contábil no LALUR (Livro de Apuração do Lucro 
Real) de forma a se apurar o lucro tributável, na prática esse não é um procedimento usual.

A principal dificuldade encontrada para se efetuar isso é que há a necessidade de se ter praticamente dois registros contábeis: um com a contabilidade de acordo com os PCGA e outro com a movimentação em paralelo (ou pelo menos dos lançamentos diferentes) do que seria de acordo com as normas tributárias, para então se fazer os ajustes. Evidentemente, um único registro é mais fácil, evita erros pela redundância e é mais barato.

Ainda que essa seja uma possibilidade que resolveria todos esses problemas, não há incentivos para que isso efetivamente ocorra. De um lado, usuários (talvez a maioria) pouco preparados para ler uma demonstração contábil acabam aceitando os relatórios de acordo com as normas tributárias; de outro, as normas contábeis editadas por profissionais de contabilidade (Ibracon e CFC) não tem força impositiva e as que têm (CVM) não abrangem todas as empresas (apenas as sociedades anônimas abertas). Assim, restam as normas editadas em forma de lei, como a 6.404/76 (Lei das Sociedades Anônimas), que por vez ou outra sofrem alterações que se confundem com as tributárias.

Contudo, não há o que discutir a respeito da importância da Contabilidade, principalmente como instrumento de avaliação e de tomada de decisões pelos vários tipos de usuários. Os relatórios contábeis elaborados segundo as normas tributárias podem até servir para o usuário governo, mas 
não necessariamente se prestam às diversas decisões que podem tomar investidores, clientes, fornecedores, empregados etc.

Assim, uma redução na interferência das normas tributárias sobre a contabilidade poderia ser feita de duas formas.

A primeira é fazer com que as normas contábeis prevaleçam sobre as tributárias, o que inclui a possibilidade de fazer com que a base de cálculo do tributo seja a mesma apurada contabilmente, como ocorre em alguns países. Dada a cultura brasileira, essa é uma hipótese pouco provável e que até poderia ter sido implantada anteriormente. Ainda dentro dessa hipótese, uma outra possibilidade seria estabelecer mecanismos, como a auditoria externa para todas as empresas, que promovam maior força impositiva às normas contábeis, o que é inviável economicamente para a maioria das empresas.

Uma segunda forma seria alterar o modelo de tributação, tanto no sentido de reduzir ou eliminar essa interferência, como no sentido de se trocar a estrutura de tributação. A redução ou eliminação pode contrariar os objetivos da administração fiscal, e a troca da estrutura não influencia apenas esse aspecto. Esta proposta da tributação por fluxos de caixa vai nesse sentido, e é por isso que estão sendo analisados vários aspectos neste trabalho. 


\subsubsection{A Interferência das Normas Tributárias com o Modelo de POR FLUXOS DE CAIXA}

Com o modelo proposto de tributação por fluxos de caixa, os problemas decorrentes da interferência da legislação tributária sobre a prática contábil se reduzem.

Isso ocorre porque não há o problema de alocação dos fluxos de caixa no tempo, como ocorre com o modelo de tributação baseado no lucro, uma vez que são recebimentos e pagamentos efetivamente ocorridos em datas determinadas.

Isso elimina a possibilidade de manipulação por meio de criação de provisões "fantasmas" e não há a necessidade de definir parâmetros para alocação dos custos dos ativos no tempo, como é o caso da depreciação.

Assim, a empresa pode seguir qualquer norma contábil, porque isso não irá interferir na forma como o tributo é calculado. A empresa não precisa fazer ajustes no LALUR por ter obedecido aos princípios contábeis para depois calcular o tributo, o que significa que não é necessário ter as quase "duas contabilidades", uma vez que o fluxo de caixa tributável independe de qualquer forma de contabilização dos resultados.

Mesmo assim, o modelo baseado em fluxos de caixa prevê a necessidade de alguns ajustes à base de cálculo, como os apontados no Capítulo 3: do valor do próprio tributo pago, dos fluxos de caixa não-tributáveis, dos fluxos não dedutíveis, dos incentivos e das compensações. Os ajustes do tributo pago, dos 
não-tributáveis e dos não dedutíveis podem ser controlados via classificação em plano de contas, não necessitando de controle extra. Os incentivos e as compensações são controlados diretamente em livro de ajuste, também não necessitando de outro tipo de controle.

Isso mostra que o modelo leva a uma maior facilidade na sua apuração, pois não há necessidade de controle extra a não ser o do próprio livro de ajuste.

Contudo, o modelo não consegue eliminar, embora não impede que sejam contornadas, as dificuldades em procedimentos fiscais, como o caso do ano-calendário.

Além disso, esse modelo não é completamente auto-aplicável, uma vez que é necessário regulamentação de alguns pontos, como se pode observar no Capítulo 3:

- Definir se as movimentações virtuais de caixa devem entrar na movimentação dos fluxos tributáveis ou ajustados em livro;

- O reconhecimento das perdas inflacionárias no caixa e os ganhos com capital de terceiros;

- Definir se os fluxos de caixa não-tributáveis devem ser um ajuste da base de cálculo do tributo;

- Definir a composição dos saldos de caixa e equivalentes-caixa.

Ainda assim, percebe-se que essa regulamentação apenas diz respeito a pontos relacionados ao fluxo de caixa em si, não interferindo em nenhum momento na forma de contabilização do patrimônio e dos resultados. 
O modelo permite, ainda, certa liberdade do fisco em definir regras para a definição da base de cálculo, como de dedutibilidade de fluxos, limites de compensação e incentivo fiscal, além das alíquotas e dos períodos de apuração.

\subsection{CUSTOS DE CONFORMIDADE}

\subsubsection{Os Custos de Conformidade}

Como visto no Capítulo 1, além da magnitude dos custos de conformidade por parte do contribuinte, verificou-se que eles são fortemente regressivos, ou seja, empresas menores têm maiores custos que as grandes.

Neste tópico, analisamos mais a fundo os motivos que levam à existência de custos por parte do contribuinte e o comportamento dos custos de conformidade com a possível alteração da apuração do IR por lucro para a apuração em base caixa.

\subsubsection{Uma explicação para os Custos de Conformidade: a ASSIMETRIA DE INFORMAÇÃo}

A existência de custos de conformidade poderia ser explicada com argumentos como o formato da estrutura do tributo que exige a execução de atividades que envolvem custos ou até mesmo a edição de leis que não levam 
em conta o quanto isso irá custar para o contribuinte, mas buscamos a essência dessa existência na Microeconomia.

A análise microeconômica básica supõe a existência de informações completas por parte de produtores e consumidores a respeito das variáveis econômicas relevantes em suas decisões, partindo do pressuposto de racionalidade plena dos agentes.

Entretanto, analisaremos a questão de um outro ponto de vista, que é o do comportamento de mercado com informações assimétricas. Isso ocorre quando algumas partes possuem mais informações que outras.

A existência de informações assimétricas explica a razão de diversos arranjos institucionais. Ela explica, por exemplo, por que as montadoras oferecem garantias para veículos novos ou por que acionistas devem monitorar o comportamento de administradores.

Um exemplo de problema que pode ocorrer quando há informações assimétricas é apresentado por Pindyck e Rubinfeld ${ }^{71}$. Suponhamos um mercado de automóveis usados, que poderia ser separado em dois: o de alta qualidade e o de baixa. Se os compradores soubessem identificar claramente a qualidade dos veículos, haveria efetivamente os dois mercados. Entretanto, na realidade, o vendedor sabe mais sobre a qualidade do automóvel que o comprador. O resultado disso pode ser observado por meio dos seguintes gráficos:

\footnotetext{
${ }^{71}$ PINDYCK, Robert S., RUBINFELD, Daniel L. Microeconomia, p. 602-4.
} 
Figura 5.2 - Demanda por Automóveis de Alta e Baixa Qualidade

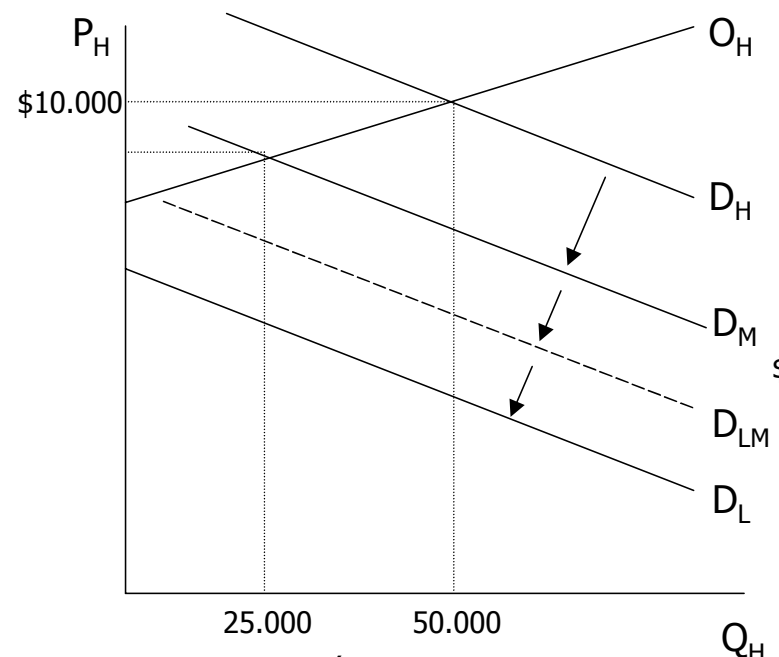

(a) Automóveis de alta qualidade

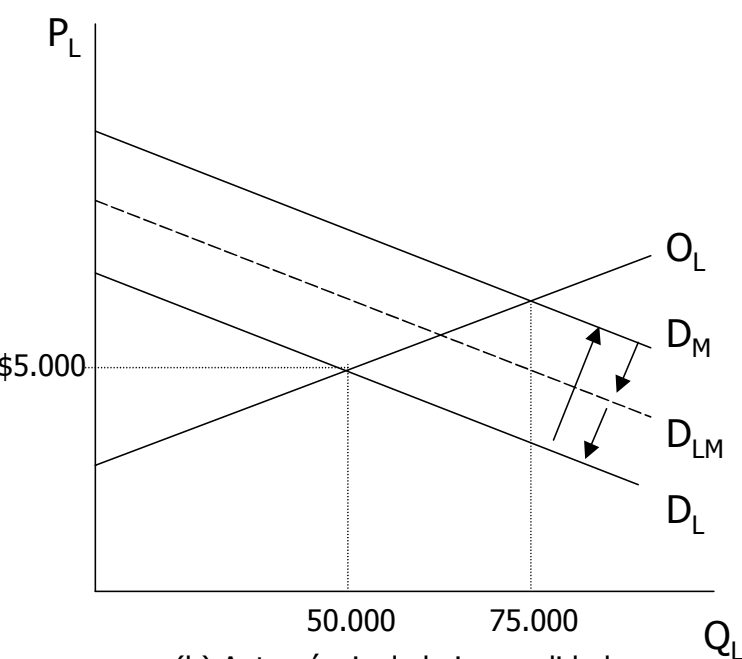

(b) Automóveis de baixa qualidade

Se os compradores soubessem a qualidade dos automóveis, em (a) a curva da demanda por automóveis de melhor qualidade seria $D_{H}$ e em (b) seria $D_{L}$, ambos com equilíbrio em 50.000 unidades. Entretanto, com informação assimétrica, ao fazer uma aquisição os compradores estão estimando que todos os automóveis tenham qualidade "média", cuja curva de demanda é $D_{M}$ em ambos os gráficos, reduzindo a quantidade demandada de (a) e aumentando a de (b). À medida que os compradores começam a perceber que a maioria dos veículos vendidos é de baixa qualidade, a curva da demanda percebida se desloca para $D_{L M}$. Essa sucessão de deslocamentos continua até que apenas automóveis de baixa qualidade sejam vendidos, em um ponto em que o preço de mercado estará baixo demais para ofertar automóveis de alta qualidade, quando a curva da demanda passa a ser $D_{L}$.

É como explicam os autores:

"Pelo fato de haver informações assimétricas, as mercadorias de baixa qualidade expulsam as de alta qualidade do mercado. 
Esse fenômeno é às vezes conhecido como problema dos produtos de qualidade duvidosa (emons problem)".

A falha de mercado ocorre quando donos de automóveis de alta qualidade os avaliam por um preço abaixo da própria avaliação dos potenciais compradores. Esse é um fenômeno conhecido como seleção adversa, conforme explicam Pindyck e Rubinfeld ${ }^{72}$ :

"A seleção adversa surge quando produtos de qualidades distintas são vendidos ao mesmo preço, porque compradores e vendedores não estão suficientemente informados para determinar a qualidade real do produto no momento da compra. Como resultado, muitos produtos de baixa qualidade $e$ poucos de alta são vendidos no mercado".

A respeito do termo seleção adversa, Milgrom e Roberts ${ }^{73}$ dizem que:

"O modelo foi cunhado na indústria de seguros. A seleção de pessoas que adquirem seguros não é uma amostra aleatória da população, mas principalmente de um grupo de pessoas com informações particulares sobre suas situações pessoais que fazem com que provavelmente eles recebam um nível acima da média de pagamentos de benefícios de acordo com a política de seguros".

No mercado de crédito, o mesmo fenômeno da seleção adversa ocorre porque o credor não consegue distinguir devedores de alta qualidade dos de baixa qualidade. Com isso, os credores devem cobrar a mesma taxa de juros de todos os devedores. Isso atrai mais devedores de baixa qualidade, exigindo uma elevação da taxa de juros.

\footnotetext{
72 PINDYCK, Robert S., RUBINFELD, Daniel L. Microeconomia, p. 604.

${ }^{73}$ MILGROM, P.R., ROBERTS, J. Economics, organization and management, p. 149.
} 
Para reduzir o problema da informação assimétrica na seleção adversa, os credores desenvolvem mecanismos para melhorar o nível de informação que Ihes permitam fazer uma melhor distinção dos devedores e evitar perdas com inadimplentes.

Pinheiro e Moura ${ }^{74}$ descrevem como isso acontece nos bancos brasileiros. As pessoas físicas e pequenas empresas (o chamado mercado de varejo), em geral, têm suas solicitações tratadas por métodos estatísticos com base nas informações fornecidas pelo cliente e/ou disponíveis em registros públicos. Já nos empréstimos para os demais mercados, o método tradicional é o estabelecimento de limites de crédito por cliente, para restringir a exposição do credor a um devedor específico. Para isso, o credor se utiliza de informações dos Bureaus de Informação de Crédito, de dados coletados por meio de análise de balanços e visitas às empresas.

A assimetria de informação traz problemas pré-contratuais porque as partes não têm informações suficientes sobre o negócio que estão realizando. De acordo com Milgrom e Roberts ${ }^{75}$ :

"A seleção adversa é um problema de oportunismo précontratual; ele surge por causa da informação particular que os consumidores têm antes de adquirir o contrato, quando estão avaliando se a compra é benéfica".

74 PINHEIRO, Armando C., MOURA, Alkimar. Segmentação e uso de informação nos mercados de crédito brasileiros, p. 12-5.

${ }^{75}$ MILGROM, P.R., ROBERTS, J. Economics, organization and management, p. 150. 
Após a realização do contrato, um outro problema pode acontecer, que é o do risco moral. Isso pode acontecer quando as ações de uma parte, provocadas por uma mudança no seu comportamento, não podem ser monitoradas pela outra parte, mas essas ações podem prejudicar a segunda. Se uma pessoa faz um seguro residencial, por exemplo, ela pode se descuidar de trancar as portas ao sair ou não instalar um sistema de alarme.

Com a existência de risco moral, as seguradoras podem se ver obrigadas a aumentar o prêmio cobrado ou mesmo deixar de oferecer determinada modalidade de seguro em função do aumento de seus custos.

\subsubsection{A AsSimetria de INFORMAÇÃo NO IMPOSTO de RENDA}

No caso do imposto de renda, temos que ver o problema em dois momentos: antes de instituir o tributo e depois. Na situação pré-instituição, podemos verificar que há o problema da assimetria de informação entre o governo e o contribuinte.

Do lado do contribuinte, podemos dizer que ele sabe mais que o governo sobre a sua própria renda, base do imposto. Pelo lado do governo, este não consegue distinguir entre aquele que tem renda tributável e deve o imposto e o que não deve imposto.

Por causa disso, o governo tem que criar mecanismos para melhorar o nível de informação sobre a renda periódica do contribuinte. Há alguns problemas nisso, porque é uma informação que deve ser atualizada a cada 
período, deve ser obtida de todos, contribuintes ou não, e deve-se ao menos obter uma estimativa de valor devido, sendo desejável o valor exato.

Desse modo, essas informações poderiam ser apuradas pelo próprio governo ou apuradas pelo contribuinte. Na primeira opção, o governo teria que arcar com os custos da obtenção dessa informação, que poderia ser feita via censo ou um controle centralizado das operações de toda a economia, o que parece inviável, dado o custo necessário para mantê-los eficientes.

Nessa opção, o contribuinte apura a sua renda, o imposto a pagar e faz a declaração ao fisco. Esta é a opção preferida pela maior eficiência do processo, em relação à que poderia ser realizada pela apuração do governo. Com a informação, o governo pode identificar quem deve imposto, e assim pode cobrá-lo.

Depois de instituir o imposto, aparece o problema do risco moral. Como a apuração da informação fica por conta do próprio contribuinte e o governo não tem mecanismos para monitorar todas as suas ações, o contribuinte pode se aproveitar de forma oportunista da situação e realizar ações que possam distorcer ou omitir dados, resultando em redução no imposto a pagar. Essas ações, que podem ser traduzidas como sonegação, fazem com que a arrecadação seja menor.

Com isso, o governo se vê obrigado a aumentar alíquotas, tornando o sistema economicamente ineficiente porque os que pagam corretamente pagam uma parcela maior por conta dos que não o fazem. 
Para minimizar o problema, o governo realiza trabalhos de auditoria fiscal nas informações dos contribuintes e aplica sanções quando verifica irregularidades ou ações que distorçam as informações. Tudo isso envolve custos no processo.

Essas são, portanto, as razões econômicas para a existência dos custos de conformidade, tanto do lado do contribuinte, como do lado do fisco.

\subsubsection{Os Mecanismos de Obtenção da Informação e Seus Custos}

Vamos analisar melhor o mecanismo utilizado para a obtenção de informações por parte do governo e os custos envolvidos nesse processo.

Para contornar o problema da seleção adversa, o governo se utiliza de suas prerrogativas para elaborar e aprovar leis que estabelecem regras para a apuração do valor periódico da renda por parte do contribuinte, como visto, além de regras para a realização do pagamento do tributo e para a declaração de informações.

Para contornar o problema do risco moral, o governo estabelece regras para a realização de auditoria fiscal, cria normas anti-elisão e anti-evasão, além de estabelecer penalidades e sanções para aqueles que descumprirem as normas estabelecidas para contornar o problema da seleção adversa.

Com as informações sendo apuradas pelo contribuinte, uma parte dos custos é sua, justamente o de levantamento dessas informações. A outra parte 
cabe ao governo, que precisa ter recursos para captar essas informações e processá-las.

Na prática, os mecanismos utilizados para a apuração da renda podem ser separados em dois: os para apuração do lucro real e os para apuração do lucro presumido (em que podemos também incluir o lucro arbitrado).

O mecanismo utilizado pelo governo para a apuração do lucro real é a apuração do lucro contábil. O governo elegeu a apuração contábil do lucro porque é um mecanismo já instituído com princípios contábeis definidos e leis exigindo a elaboração da escrituração. Com isso, se aproveita a informação já levantada, reduzindo o custo de adaptação em relação a alguma outra forma de apuração da renda tributável.

Além disso, o governo se utiliza de mecanismos para definir qual é a informação que precisa, estabelecendo regras de escrituração contábil e ajustes ao lucro apurado, que é feito por meio do LALUR.

Como a apuração do lucro real envolve a escrituração contábil, há consigo todos os gastos inerentes: com pessoal em termos de salários, treinamento e atualização, com a aquisição de ativos, com materiais e serviços externos e outros impostos.

Entretanto, o processo de pagar o imposto não se resume apenas à atividade de escrituração contábil. As atividades envolvidas em todo o processo podem ser vistas na tabela apresentada por Bertolucci e Nascimento ${ }^{76}$ :

\footnotetext{
${ }^{76}$ BERTOLUCCI, Aldo V. NASCIMENTO, Diogo T. Quanto custa pagar tributos?, p. 57.
} 
Tabela 5.5- Quanto Custa Pagar Imposto?

\begin{tabular}{|l|c|c|c|}
\hline \multicolumn{4}{|c|}{ (Valores em milhares de reais) } \\
\hline \multicolumn{3}{|c|}{ Todas as empresas } \\
\hline \multicolumn{3}{|c|}{ Receita bruta total das empresas: R\$ $\mathbf{4 8 . 1 3 1 . 8 4 0}$} & \multicolumn{1}{c|}{ Empresas: $\mathbf{2 5}$} \\
\hline Área da empresa & Valor & \% Parcial & \% Total \\
\hline Conselho de Administração & 4.007 & 3,24 & 2,56 \\
\hline Conselho Fiscal & 70 & 0,06 & 0,04 \\
\hline Diretoria & 5.494 & 4,45 & 3,51 \\
\hline Controladoria & 33.487 & 27,12 & 21,42 \\
\hline Jurídico & 10.598 & 8,58 & 6,78 \\
\hline Informática & 8.813 & 7,14 & 5,64 \\
\hline Arquivo & 1.872 & 1,52 & 1,20 \\
\hline Impostos indiretos & 37.848 & 30,65 & 24,20 \\
\hline Custos & 1.718 & 1,39 & 1,10 \\
\hline Recursos Humanos & 4.619 & 3,74 & 2,95 \\
\hline Preços de Transferência & 2.394 & 1,94 & 1,53 \\
\hline Impostos de Importação & 6.752 & 5,47 & 4,32 \\
\hline Tesouraria & 1.375 & 1,11 & 0,88 \\
\hline Auditoria Interna & 1.282 & 1,04 & 0,82 \\
\hline Registros & 3.154 & 2,55 & 2,02 \\
\hline Total Custos Internos & $\mathbf{1 2 3 . 4 8 3}$ & $\mathbf{1 0 0 , 0 0}$ & $\mathbf{7 8 , 9 7}$ \\
\hline Incidência sobre a receita bruta & $0,26 \%$ & & \\
\hline Auditores e consultores & 4.069 & 12,37 & 2,60 \\
\hline Advogados & 11.608 & 35,30 & 7,42 \\
\hline Diversos & 2.401 & 7,30 & 1,54 \\
\hline Arquivos Terceirizados & 605 & 1,84 & 0,39 \\
\hline Despachantes Aduaneiros & 3.341 & 10,16 & 2,14 \\
\hline Informática & 10.864 & 33,03 & 6,95 \\
\hline Total Custos Externos & $\mathbf{3 2 . 8 8 8}$ & $\mathbf{1 0 0 , 0 0}$ & $\mathbf{2 1 , 0 3}$ \\
\hline Incidência sobre a receita bruta & $0,07 \%$ & & \\
\hline Total Custos de Conformidade & 156.371 & & 100,00 \\
\hline Incidência sobre a receita bruta & $\mathbf{2 5 . 5 6 4}$ & & \\
\hline Economia prevista & $16,35 \%$ & & \\
\hline Redução \% & $0,05 \%$ & & \\
\hline Incidência sobre a receita bruta & & & \\
\hline
\end{tabular}

Essa tabela foi elaborada pelos referidos autores com base em pesquisa com 25 empresas. Os custos são referentes apenas aos decorrentes do cumprimento de obrigações tributárias em cada uma das atividades listadas. 0 item denominado Economia Prevista se refere ao que poderia ser economizado caso a legislação não mudasse mais. 
Esses custos apresentados se referem ao cumprimento das obrigações de todos os tributos, ou seja, não é possível isolar o custo do IR. Entretanto, isso dá uma melhor idéia de que os custos que ficam por conta do contribuinte não se restringem apenas ao custo da apuração do lucro tributável, mas envolve uma série de atividades.

\subsubsection{Os Custos de Conformidade do Contribuinte no Modelo de Tributação por FluXos de CaIXA}

Adaptando essa listagem da Tabela 5.5, podemos descrever o processo de pagar qualquer tributo da seguinte forma (podendo diferir de empresa para empresa):

Tabela 5.6 - As Fases do Processo de Pagar Tributo

\begin{tabular}{|l|l|l|}
\hline Fase Pré-Apuração do Tributo & Fase de Apuração do Tributo & Fase Pós-Apuração do Tributo \\
\hline - Conhecimento das normas tributárias & - Identificação dos Fatos & - Pagamento do Tributo \\
- Treinamento & - Mensuração dos Fatos & - Procedimentos Tesouraria \\
- Consultoria & - Registro dos Fatos & - Controles \\
- Análise de Planej. Tributário & - Cálculo do tributo & - Contábeis \\
- Preparação sistema de informação & - Apuração base cálculo & - Extra-contábeis \\
- Elaboração do sistema & - Ajustes & - Arquivo \\
- Adaptações no sistema & - Apuração do tributo & - Auditoria Interna e Externa \\
& & - Consultoria \\
& & - Assessoria Jurídica \\
\hline
\end{tabular}

Assim, podemos ter uma visão mais completa dos custos de conformidade com a apuração do lucro real, que passa também, com maior ou menor intensidade dependendo da empresa, por esse mesmo processo. 
A apuração do lucro presumido tem por base a receita de vendas, a receita financeira e outras receitas. A princípio, por ser mais simplificado, os custos de conformidade seriam menores em relação à apuração pelo lucro real.

De fato, essa sistemática agiliza a apuração do tributo porque depende basicamente da apuração apenas das receitas em base competência, o que dispensaria a apuração dos custos e despesas, que demandam um número maior de horas de mão-de-obra. Além disso, essa base está menos sujeita a alterações de legislação, além de ser mais simples e menos volumosa.

Com isso, determinados custos que estão relacionados diretamente com a forma de apuração do tributo se reduzem. Aproveitando o processo de pagar tributos, descrito acima, pode haver reduções nas seguintes atividades: treinamento, consultoria na Fase Pré-Apuração, análise do planejamento tributário, elaboração do sistema e suas adaptações, cálculo do tributo, controles, auditoria, consultoria na Fase Pós-Apuração e assessoria jurídica.

Os custos só não se reduzem mais porque para as empresas têm, além de ter que apurar outros tributos, a obrigação da escrituração contábil por parte de outras leis: da legislação comercial, da legislação civil, da legislação trabalhista e previdenciária e da lei das sociedades anônimas. Isso a obriga a incorrer nos custos que envolvem a contabilidade. Além disso, pode ocorrer o problema da indivisibilidade dos recursos geradores dos custos, diminuindo a possibilidade de sua redução.

No modelo de tributação por fluxos de caixa, o que muda em relação ao imposto de renda apurado pelo lucro real é a sua forma de apuração. 
O fluxo de caixa não depende necessariamente da contabilidade, embora também possa ser feito por esse método. Ele pode utilizar a mesma base de qualquer sistema de tesouraria, apenas com adaptações em termos de estrutura de informação, realizando a classificação dos fluxos com um plano de contas direcionado a esse fim.

Dentro do processo de pagar o tributo, diversas atividades tendem a ter seus custos reduzidos em relação à tributação pelo lucro, pelos seguintes motivos:

- o fluxo de caixa é mais objetivo e demanda menor regulamentação, o que reduz o custo de treinamento, consultoria e planejamento tributário;

- o fluxo de caixa, em termos de sistema de informação, pode ser adaptado de um sistema de tesouraria, presente na maioria das empresas;

- para elaborá-lo, não se requer conhecimento contábil, o que reduz o custo de treinamento;

- o cálculo, incluindo a apuração da base de cálculo, os ajustes e a apuração do tributo, é mais ágil;

- a auditoria pode ser mais simples porque há menos exames a realizar, embora seja necessária a criação de novos procedimentos.

Outras atividades desse processo podem não ter seus custos reduzidos com o modelo de tributação por fluxos de caixa, em função da agregação de mais uma atividade que é a apuração dos fluxos de caixa e a apuração dos tributos respectivos à própria atividade de escrituração contábil. 


\subsubsection{Custos de Conformidade do Governo}

Tomando agora o ponto de vista do governo enquanto arrecadador de imposto de renda, a única informação que ele precisa de fato para resolver o problema da seleção adversa é o imposto devido de cada contribuinte.

Porém, para isso é necessário ter todo um aparato para captar a informação, processá-la, identificar os devedores, realizar a cobrança, receber, confrontar o devido com o recebido e iniciar um novo processo de cobrança dos restantes.

No caso do IR, a ordem desse processo é diferente. A cobrança não é realizada após a identificação dos devedores por parte do governo, mas antes mesmo de captar a informação, pois o contribuinte sabe se é devedor ou não antes do governo. Com isso, ele mesmo efetua o recolhimento e só depois é que faz a declaração, que é processada pelo governo e o processo continua com as demais etapas.

Para minimizar o problema do risco moral, o governo realiza ações de fiscalização por diversos meios, para saber se o contribuinte realizou ações que pudessem modificar a informação cuja incumbência o governo passou para ele apurar.

Assim, podemos classificar as atividades de arrecadação do IR da seguinte forma: 
Tabela 5.7 - As Fases do Processo de Arrecadação do Tributo

\begin{tabular}{|l|l|l|}
\hline \multicolumn{1}{|c|}{ Fase Pré-Recebimento } & \multicolumn{1}{|c|}{ Fase de Recebimento } & \multicolumn{1}{c|}{ Fase Pós-Recebimento } \\
\hline - Elaboração e aprovação de & - Processamento cobrança & - Recebimento de declarações \\
normas tributárias & - Registro das receitas & - Processamento das declarações \\
- Treinamento de funcionários & - Identificação dos pagadores & - Identificação dos devedores \\
- Preparação sistemas informação & & - Cobrança dos devedores \\
- Atendimento de contribuintes & & - Auditoria fiscal \\
- Processos administrativos & & - Processos administrativos \\
- Processos judiciais & & - Processos judiciais \\
& & - Atendimento de contribuintes \\
\hline
\end{tabular}

Com o modelo de tributação por fluxos de caixa, na Fase de Prérecebimento, pode haver reduções nas seis atividades, em função da menor necessidade de regulamentação e maior simplicidade do modelo, em comparação com a tributação por lucro. Em relação aos processos administrativos e judiciais que ocorrem nessa fase, principalmente de caráter preventivo por parte do contribuinte, podem se reduzir também em função da menor margem de aspectos ligados à regulamentação que podem ser contestados.

Na Fase de Recebimento, é possível que não haja modificações, porque o processo é semelhante.

Na Fase Pós-Recebimento, pode haver reduções nas atividades relacionadas às declarações, uma vez que não é necessário incluir na declaração as demonstrações contábeis, mas apenas a demonstração dos fluxos de caixa tributáveis, o que reduz em muito o volume de dados a serem processados e analisados.

O mesmo pode não acontecer com as atividades de identificação e cobrança dos devedores, porque o processo também é semelhante. 
Em relação à atividade de auditoria fiscal, não podemos dizer que poderia haver redução significativa nos custos, porque atualmente, segundo a Secretaria de Receita Federal, essa atividade tem sido fortemente realizada com o auxílio de sistemas informatizados de apoio à seleção de contribuintes, de apoio à execução fiscal e da chamada malha fiscal.

Com esse auxílio, é realizada a seleção dos contribuintes suspeitos, normalmente por cruzamento de informações. A partir disso, a fiscalização investiga os pontos específicos apontados na seleção, o que faz com que exames completos em registros contábeis sejam feitos excepcionalmente. Por conta disso, a atividade de auditoria não teria alterações relevantes nos custos com uma eventual mudança para o modelo com base no fluxo de caixa.

Ainda assim, em um exame completo de auditoria fiscal, o principal objeto passaria a ser a movimentação de caixa, ao invés do exame de todas as contas patrimoniais e de resultado, necessário pela sistemática do lucro real. A movimentação de caixa deve ser checada com a documentação de origem, para se verificar se os pagamentos e recebimentos compõem o fluxo tributável ou não. Há um complicador nesse processo, que são as movimentações virtuais de caixa tributáveis, que demandam procedimentos alternativos para que sejam checadas mesmo que o contribuinte não as declare.

As disputas administrativas e judiciais também tendem a ter uma redução em função da menor necessidade de normatização e conseqüente diminuição na margem de discussão de direitos. 
Com tudo isso, há possibilidade de redução dos custos de conformidade também por parte do governo, apenas com a mudança na forma de apuração do imposto de renda, passando da base lucro para a base fluxo de caixa.

\subsection{ARRECADAÇÃO}

\subsubsection{A ArRecadação com o Modelo de Tributação sobre fluxos de CAIXA}

Uma preocupação pertinente em relação ao modelo de tributação sobre fluxos de caixa é a arrecadação.

Em uma análise simplista, poder-se-ia pensar na possibilidade de 0 governo ficar um determinado tempo sem arrecadação pelo fato de que os investimentos normalmente são realizados antes e os fluxos de caixa vêm depois, o que postergaria o recebimento dos impostos por parte do governo.

Entretanto, se o modelo fosse implantado neste exato momento, os contribuintes não estariam todos iniciando suas atividades agora; a grande maioria estaria com seus empreendimentos em marcha, eventualmente realizando novos investimentos, e uma outra parte efetivamente iniciando suas operações.

A passagem do modelo baseado em lucro para o baseado em caixa não resulta necessariamente, na prática, na postergação do recebimento dos impostos. Na verdade, o que ocorre é o deslocamento do fato gerador do 
período de competência dos lucros para o período de geração de caixa, o que não significa que o governo estará deixando de arrecadar durante um tempo, porque no mesmo período de ocorrência dos lucros há também geração de caixa. Essa questão somente é ponto de discussão quando o assunto é a fase de transição de um modelo para outro.

\subsubsection{Estudo sobre Diferenças de ArRecadação}

Para a fase pós-implementação do modelo, a preocupação deve ser apenas em relação ao volume de arrecadação, ou seja, se o governo pode arrecadar mais ou menos em relação ao que é arrecadado com o IR em base competência, e em quanto, para poder definir alíquotas e outros mecanismos de compensação de eventuais perdas ou excesso de carga tributária.

Para realizar um estudo detalhado sobre isso, seria necessário fazer uma simulação da arrecadação a partir dos dados de todos os contribuintes, comparando o valor recolhido com o valor que seria a partir da geração de caixa. Contudo, essa simulação só seria possível com os dados da Secretaria da Receita Federal do Ministério da Fazenda, os quais não tivemos acesso.

Mesmo assim, é possível pelo menos verificar se a arrecadação seria significativamente diferente, a partir de dados contábeis publicados. Para isso, realizamos um teste estatístico de hipótese de diferença de médias a partir da base de dados da Economática Ltda, com conteúdo obtido a partir de demonstrações contábeis. 
Foram selecionadas empresas brasileiras com ações na Bovespa (Bolsa de Valores do Estado de São Paulo), sendo que para a amostra foram obtidos os números de apenas uma ação ou observação por empresa. Foram utilizados os dados ajustados pela inflação (índice IGPDI/FGV Acumulado) até $31 / 12 / 2002$.

O objetivo do teste é verificar se o lucro líquido tem correspondência com os fluxos de caixa das operações mais os de investimento. Isso já foi demonstrado em termos teóricos neste trabalho, mas o intuito aqui é observar o comportamento real das empresas, porque não necessariamente eles são iguais em períodos intertemporais. Sendo correspondentes, a arrecadação com a tributação do imposto de renda por lucro ou por caixa seria equivalente.

Assim, foi utilizada a "Ferramenta de Análise Teste-T: Duas Amostras em Par para Médias" do software MS-Excel 2000, que executa o teste de hipótese de diferença de médias, utilizado quando se quer saber se os valores de uma amostra são, em média, iguais aos valores de outra, ou seja, se a média das diferenças entre as amostras difere significativamente ou não de zero.

Foi realizado um teste bi-caudal, com o número de graus de liberdade igual ao tamanho da amostra (n) menos 1 , com $5 \%$ de nível de confiança. A hipótese nula é de que a diferença de médias é igual a zero, e a hipótese alternativa é a de que a diferença de médias é diferente de zero:

$$
\begin{aligned}
& H_{o}: \mu_{d}=0 \\
& H_{a}: \mu_{d} \neq 0
\end{aligned}
$$


Para esse teste, foram obtidos os valores dos Lucros Líquidos dessas empresas de 1998 a 2002 (5 anos) e a Geração de Caixa Operacional mais Investimentos.

Os valores dos Lucros Líquidos foram obtidos diretamente da base de dados.

Já a geração de caixa operacional mais investimentos precisou de cálculos adicionais porque na base de dados da Economática não há dados da Demonstração dos Fluxos de Caixa (até porque no Brasil essa demonstração ainda não é obrigatória). Na geração de caixa operacional mais de investimento, não entram os relacionados às atividades de financiamento, que são os referentes a venda de ações emitidas, a empréstimos obtidos no mercado, a recebimento de contribuições ou doações, a pagamento de dividendos, pagamento de empréstimos obtidos (exceto juros) e pagamento do principal referente a imobilizado adquirido a prazo. Esses fluxos estão relacionados a transações com contrapartida em Patrimônio Líquido e Passivos Onerosos (compostos por empréstimos e financiamentos que geram despesas financeiras). Desse modo, foram excluídas do cálculo as movimentações que pudessem estar relacionadas com essas contas.

Para chegar, então, ao Fluxo de Caixa Operacional mais Investimentos, utilizou-se a seguinte fórmula:

Fluxo de Caixa Operacional + Investimentos $=$ Lucro/prejuízo Líquido

(+) Ajustes de itens que não afetam o caixa

(-) Variações nos ativos não-caixa

$(+)$ Variações nos passivos não-onerosos 
O lucro/prejuízo líquido do período foi ajustado pelos itens que não afetam o caixa para não se efetuar a dupla contagem de parte dos fluxos de caixa de investimentos que são computados no lucro.

Ele foi ajustado também pelas variações nos ativos e passivos circulantes e de longo prazo (exceto os passivos onerosos) porque isso representa a geração/consumo de caixa das operações. A variação do ativo permanente representa a geração/consumo de caixa em investimentos, em termos líquidos. Desse modo, o ajuste do lucro pode ocorrer pelas variações nos ativos nãocaixa e nos passivos não-onerosos.

A partir disso, foram levantadas as seguintes variáveis da base de dados da Economática:

- Lucro Líquido, de 1998 a 2002, que consta da DRE;

- Itens Que Não Afetam o CCL, de 1998 a 2002. Na Economática, esse número é composto por:

- Depreciação e Amortização

- Variações Monetárias de LP

○ Provisões Itens não Circulantes

- Venda de Ativo Fixo

- Amortização de Deságio em Investimentos

- Ganhos em Participações Societárias

○ Equivalência Patrimonial

- Ajustes de Exercícios Anteriores

- Credito Tributário a Recuperar 
○ Imposto Renda Diferido

- Mútuo com Controladas

○ Provisão para Perdas em Investimentos

- Participações dos Minoritários

- Provisões Diversas

- Outros Fluxos de Cx Operacionais

- Total do Ativo no final dos anos de 1997 a 2002;

- Valor da Reserva de Reavaliação no final dos anos de 1997 a 2002;

- Saldo de Disponibilidades no final dos anos de 1997 a 2002;

- Total do Passivo Circulante no final dos anos de 1997 a 2002;

- Total do Exigível a Longo Prazo no final dos anos de 1997 a 2002;

- Valor dos Financiamentos de Curto Prazo no final dos anos de 1997 a 2002;

- Valor dos Financiamentos de Longo Prazo no final dos anos de 1997 a 2002. Assim, para se chegar à geração de caixa operacional mais investimentos a partir do lucro líquido, foi necessário ajustá-lo da seguinte forma:

- somar o valor dos Itens Que Não Afetam o $\mathrm{CCL}$, obtido da DOAR (Demonstração das Origens e Aplicações de Recursos). Esse dado corresponde ao ajuste dos itens que não afetam o caixa;

- subtrair as variações nos ativos não-caixa. Para isso, foram subtraídos do Total do Ativo o Valor da Reserva de Reavaliação (cuja contrapartida no ativo imobilizado pode nunca se realizar em caixa, se não for vendido, e mesmo que seja, o resultado já está considerado no lucro líquido) e o 
próprio Saldo de Disponibilidades. A variação é a diferença desses valores do final de um período a outro;

- somar as variações nos passivos não-onerosos. Para isso, foram somados o Total do Passivo Circulante e do Exigível a Longo Prazo, e subtraídos disso o valor dos Financiamentos de Curto e de Longo Prazos. A variação é dada pela diferença desses valores do final de um período a outro.

Com isso, chegou-se às duas variáveis de comparação: Lucro Líquido e Geração de Caixa Operacional mais Investimentos.

Primeiramente, o objetivo foi verificar em um prazo mais longo se as médias dessas duas variáveis seriam equivalentes, porque poderia haver uma tendência maior de se igualarem, principalmente em função de a geração de caixa incluir os fluxos de investimentos, que são computados como depreciação e outras amortizações.

Assim, foi realizado o teste de hipótese para o período de 1998 a 2002 (5 anos), com os seguintes resultados obtidos com o MS Excel 2000:

Tabela 5.8 - Geração de Caixa e Lucro Líquido Período 1998-2002 Teste-t: duas amostras em par para médias

\begin{tabular}{lrr}
\hline & Ger.Caixa & Lucro Líquido \\
& $1998-2002$ & $1998-2002$ \\
\hline Média & 1179872,517 & 576360,5464 \\
Variância & $4,17737 \mathrm{E}+13$ & $1,00556 \mathrm{E}+13$ \\
Observações & 302 & 302 \\
Correlação de Pearson & 0,791394161 & \\
Hipótese da diferença de média & 0 & \\
gl & 301 & \\
Stat $\mathrm{t}$ & 2,381804586 & \\
$\mathrm{P}(\mathrm{T}<=\mathrm{t})$ uni-caudal & 0,008924638 & \\
$\mathrm{t}$ crítico uni-caudal & 1,649932528 & \\
$\mathrm{P}(\mathrm{T}<=\mathrm{t})$ bi-caudal & 0,017849276 & \\
$\mathrm{t}$ crítico bi-caudal & 1,967878234 & \\
\hline
\end{tabular}


A média de geração de caixa é estatisticamente igual à média de lucro líquido quando a Estatística t (Stat $t$ ) está entre $-1,9679$ e $+1,9679$, que são as extremidades da curva com $95 \%$ de confiança.

Verifica-se que o Stat $t$ não está dentro do intervalo, rejeitando-se a hipótese.

Em uma primeira análise, poder-se-ia dizer que as médias não são iguais e portanto a arrecadação pelo modelo de fluxos de caixa seria diferente da por lucro.

Entretanto, é preciso analisar porque ocorreu esse resultado diferente do esperado. Para isso, foram elaborados outros cinco testes, um para cada ano do período. As tabelas estão reproduzidas a seguir, com os anos identificados nas colunas da tabela:

Tabela 5.9 - Geração de Caixa e Lucro Líquido de 1998 Teste-t: duas amostras em par para médias

\begin{tabular}{lrr}
\hline & Ger.Caixa & Lucro Líquido \\
& \multicolumn{1}{c}{1998} & 1998 \\
\hline Média & $-172053,5762$ & 103179,1391 \\
Variância & $2,78769 \mathrm{E}+12$ & $3,33337 \mathrm{E}+11$ \\
Observações & 302 & 302 \\
Correlação de Pearson & 0,124146285 & \\
Hipótese da diferença de média & 0 & \\
gl & 301 & \\
Stat $\mathrm{t}$ & $-2,817608191$ & \\
$\mathrm{P}(\mathrm{T}<=\mathrm{t})$ uni-caudal & 0,002579206 & \\
$\mathrm{t}$ crítico uni-caudal & 1,649932528 & \\
$\mathrm{P}(\mathrm{T}<=\mathrm{t})$ bi-caudal & 0,005158411 & \\
$\mathrm{t}$ crítico bi-caudal & 1,967878234 & \\
\hline
\end{tabular}


Tabela 5.10 - Geração de Caixa e Lucro Líquido de 1999

Teste-t: duas amostras em par para médias

\begin{tabular}{lrr}
\hline & Ger.Caixa & \multicolumn{2}{c}{ Lucro Líquido } \\
& \multicolumn{1}{c}{1999} & 1999 \\
\hline Média & 332804,3377 & 71445,32781 \\
Variância & $3,81677 \mathrm{E}+12$ & $1,52665 \mathrm{E}+11$ \\
Observações & 302 & 302 \\
Correlação de Pearson & 0,406091146 & \\
Hipótese da diferença de média & 0 & \\
gl & 301 & \\
Stat $\mathrm{t}$ & 2,481722458 & \\
$\mathrm{P}(\mathrm{T}<=\mathrm{t})$ uni-caudal & 0,00681024 & \\
$\mathrm{t}$ crítico uni-caudal & 1,649932528 & \\
$\mathrm{P}(\mathrm{T}<=\mathrm{t})$ bi-caudal & 0,013620479 & \\
$\mathrm{t}$ crítico bi-caudal & 1,967878234 & \\
\hline
\end{tabular}

Tabela 5.11 - Geração de Caixa e Lucro Líquido de 2000

Teste-t: duas amostras em par para médias

\begin{tabular}{lrr}
\hline & Ger.Caixa & \multicolumn{2}{c}{ Lucro Líquido } \\
& 2000 & 2000 \\
\hline Média & 276145,003 & 178086,8874 \\
Variância & $2,6654 \mathrm{E}+12$ & $8,82564 \mathrm{E}+11$ \\
Observações & 302 & 302 \\
Correlação de Pearson & 0,8376725 & \\
Hipótese da diferença de média & 0 & \\
gl & 301 & \\
Stat $\mathrm{t}$ & 1,72277434 & \\
$\mathrm{P}(\mathrm{T}<=\mathrm{t})$ uni-caudal & 0,04297821 & \\
$\mathrm{t}$ crítico uni-caudal & 1,64993253 & \\
$\mathrm{P}(\mathrm{T}<=\mathrm{t})$ bi-caudal & 0,08595643 & \\
$\mathrm{t}$ crítico bi-caudal & 1,96787823 & \\
\hline
\end{tabular}


Tabela 5.12 - Geração de Caixa e Lucro Líquido de 2001

Teste-t: duas amostras em par para médias

\begin{tabular}{lrr}
\hline & \multicolumn{1}{c}{ Ger.Caixa } & Lucro Líquido \\
& 2001 & \multicolumn{1}{c}{2001} \\
\hline Média & 272211,8874 & 156845,7947 \\
Variância & $5,80013 \mathrm{E}+12$ & $8,73217 \mathrm{E}+11$ \\
Observações & 302 & 302 \\
Correlação de Pearson & 0,810716193 & \\
Hipótese da diferença de média & 0 & \\
gl & 301 & \\
Stat t & 1,152839695 & \\
$\mathrm{P}(\mathrm{T}<=\mathrm{t})$ uni-caudal & 0,124945441 & \\
t crítico uni-caudal & 1,649932528 & \\
$\mathrm{P}(\mathrm{T}<=\mathrm{t})$ bi-caudal & 0,249890881 & \\
t crítico bi-caudal & 1,967878234 & \\
\hline
\end{tabular}

Tabela 5.13 - Geração de Caixa e Lucro Líquido de 2002

Teste-t: duas amostras em par para médias

\begin{tabular}{lrr}
\hline & \multicolumn{1}{c}{$\begin{array}{c}\text { Ger.Caixa } \\
\text { 2002 }\end{array}$} & $\begin{array}{r}\text { Lucro Líquido } \\
\text { 2002 }\end{array}$ \\
\hline Média & 470764,8642 & 66803,39735 \\
Variância & $2,04971 \mathrm{E}+12$ & $5,90748 \mathrm{E}+11$ \\
Observações & 302 & 302 \\
Correlação de Pearson & 0,162223627 & \\
Hipótese da diferença de média & 0 & \\
gl & 301 & \\
Stat $\mathrm{t}$ & 4,645669784 & \\
$\mathrm{P}(\mathrm{T}<=\mathrm{t})$ uni-caudal & $2,53691 \mathrm{E}-06$ & \\
$\mathrm{t}$ crítico uni-caudal & 1,649932528 & \\
$\mathrm{P}(\mathrm{T}<=\mathrm{t})$ bi-caudal & $5,07383 \mathrm{E}-06$ & \\
$\mathrm{t}$ crítico bi-caudal & 1,967878234 & \\
\hline
\end{tabular}

Um último teste foi realizado, pegando todo o período de 1998 a 2001 (4 anos) e o resultado é o seguinte: 
Tabela 5.14 - Geração de Caixa e Lucro Líquido Período 1998-2001

Teste-t: duas amostras em par para médias

\begin{tabular}{lrr}
\hline & $\begin{array}{r}\text { Ger.Caixa } \\
\text { Lédia }\end{array}$ & \multicolumn{1}{c}{ Lucro Líquido } \\
Variância & $7098-2001$ & $1998-2001$ \\
\hline Observações & $3,38028 \mathrm{E}+13$ & $6,30184 \mathrm{E}+12$ \\
Correlação de Pearson & 302 & 302 \\
Hipótese da diferença de média & 0,807985248 & \\
gl & 0 & \\
Stat $\mathrm{t}$ & 301 & \\
$\mathrm{P}(\mathrm{T}<=\mathrm{t})$ uni-caudal & 0,853220158 & \\
$\mathrm{t}$ crítico uni-caudal & 0,197107836 & \\
$\mathrm{P}(\mathrm{T}<=\mathrm{t})$ bi-caudal & 1,649932528 & \\
$\mathrm{t}$ crítico bi-caudal & 0,394215671 & \\
\hline
\end{tabular}

Para facilitar a verificação e a análise, elaboramos um quadro resumo com os principais valores dessas tabelas, a seguir:

\begin{tabular}{|c|c|c|c|}
\hline \multirow[b]{2}{*}{ Anos } & \multirow[b]{2}{*}{ Stat $\mathbf{t}$} & \multicolumn{2}{|c|}{ Média } \\
\hline & & $\begin{array}{c}\text { Geração de } \\
\text { Caixa }\end{array}$ & $\begin{array}{l}\text { Lucro } \\
\text { Líquido }\end{array}$ \\
\hline 1998 & $-2,8176$ & $(172.054)$ & 103.179 \\
\hline 1999 & 2,4817 & 332.804 & 71.445 \\
\hline 2000 & 1,7228 & 276.145 & 178.087 \\
\hline 2001 & 1,1528 & 272.212 & 156.846 \\
\hline 2002 & 4,6457 & 470.765 & 66.803 \\
\hline 1998 a 2001 & 0,8532 & 709.108 & 509.557 \\
\hline 1998 a 2002 & 2,3818 & 1.179 .873 & 576.361 \\
\hline Idal & 1,9679 & & \\
\hline
\end{tabular}

Pode-se observar que, dos cinco anos, apenas 2000 e 2001 estão dentro do intervalo de igualdade. Isso também acontece com o teste realizado para o período de 1998 a 2001. Além disso, pode-se verificar também que, à exceção de 1998, em todos os anos a geração de caixa teve uma média maior que o lucro, assim como no período de 1998 a 2002. 
Disso tudo, o que se pode inferir é que não há um comportamento regular na relação entre lucro e caixa nem em um prazo curto e nem em um alongado.

Isso se explica pelo comportamento errático da geração de caixa e pelo próprio comportamento do lucro, que caminha de acordo com as diversas condições do mercado.

Além disso, pode-se afirmar que a geração de caixa pode ter um comportamento com desvios maiores em relação à média que o lucro, como pode ser visto no seguinte gráfico, que mostra a evolução de ambas as variáveis ao longo dos cinco anos do estudo:

Figura 5.3- Comportamento Geração de Caixa e Lucro Líquido

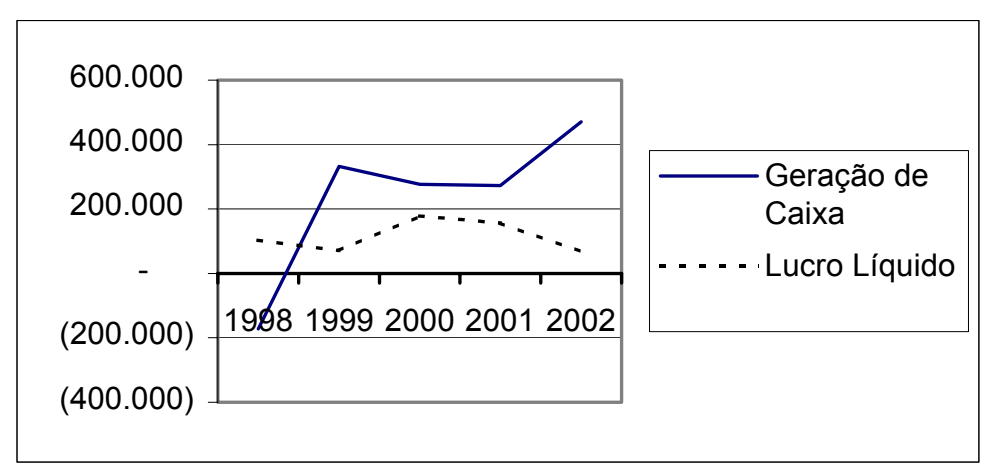

Isso significa que não é possível prever com segurança, nesta metodologia, qual deve ser a arrecadação no futuro, mas ao mesmo tempo é possível afirmar que a arrecadação até pode ser equivalente em determinados períodos ou mesmo ao longo de vários períodos. 


\subsubsection{EvasÃo e ElisÃo FisCAL}

Em relação à evasão e elisão fiscal, vamos analisar essas questões apenas do ponto de vista das diferenças entre o modelo baseado em lucro e o baseado em fluxo de caixa, principalmente porque outras formas de evasão e elisão não ligadas a essas diferenças podem continuar existindo porque o que muda é apenas a forma de apuração do valor tributável. As diferenças dos dois modelos, para efeito de evasão e elisão, estão relacionadas à questão de competência/caixa.

Em relação à elisão fiscal no modelo baseado em lucro, o que pode acontecer é o reposicionamento dos resultados no tempo. Isso pode ser feito com a postergação de receitas e/ou antecipação de custos e despesas, que resultam na postergação do imposto.

No modelo de tributação por fluxos de caixa, esse tipo de artifício só vai ocorrer se a empresa efetivamente postergar o recebimento ou antecipar 0 pagamento, mas há um incentivo menor nessa forma de elisão, porque o benefício do recebimento é maior que o ônus do pagamento do tributo.

No modelo lucro, um exemplo de elisão com reposicionamento dos resultados é o leasing. Ao invés de adquirir o ativo, se faz o arrendamento financeiro, postergando-se o valor do imposto pelo fato de as despesas serem os pagamentos das parcelas e não a depreciação, que ocorreria ao longo de um período normalmente maior. No modelo caixa, fazer o leasing pode ser até pior que adquirir o ativo, dependendo do prazo de pagamento. 
Justamente pelo motivo de os investimentos serem dedutíveis do imposto, poder-se-ia pensar em outras formas de elisão relacionadas a isso, como aumentar o nível de investimentos para pagar menos imposto. Isso de fato pode ocorrer, porque se os investimentos são dedutíveis, há grandes chances de, em determinados momentos, a empresa ficar sem pagar o tributo por conta dos desembolsos efetuados, acima da geração operacional de caixa e de outros fluxos tributáveis, mantendo a base de cálculo negativa ou reduzida.

Nesse momento, o sacrifício do desembolso pelo investimento é maior que o sacrifício do desembolso do imposto. Entretanto, a percepção da empresa é que o investimento tende a trazer um retorno maior que o pagamento do imposto. Isso faz com que haja um incentivo maior à aquisição de ativos do que ao pagamento dos tributos.

Para o governo, isso representa realmente uma postergação do imposto, mas há outros fatores que podem amenizar o problema:

- a geração de caixa no futuro provavelmente tende a ser maior do que sem os investimentos, o que é saudável para a economia como um todo;

- a decisão de investimentos depende de uma série de variáveis, e não apenas da questão tributária;

- durante todo o ciclo de vida da empresa, não é a todo momento que ela realiza investimentos;

- o estudo realizado anteriormente sobre arrecadação mostra que a geração de caixa, mesmo com investimentos, pode ser até igual ao lucro, na média das empresas. 
Em relação à evasão, o que pode acontecer relacionado à apuração do lucro é a redução fictícia do lucro via omissão de receitas ou aumento de despesas.

Por fluxos de caixa, isso também pode ocorrer porque podem ser omitidos recebimentos ou criados de forma fictícia determinados pagamentos.

Entretanto, como a principal base documental do imposto sobre o lucro é a nota fiscal e a do imposto sobre fluxo de caixa é o recibo de pagamento, pode ocorrer um problema de assimetria de informação favorável ao governo.

A omissão de receitas pode acontecer porque 0 vendedor, com 0 consentimento do comprador, não emite a nota fiscal. Com isso, o comprador também não pode deduzir esse valor de sua base de cálculo do tributo.

Contudo, é mais difícil o comprador consentir com a não emissão do recibo, porque esse é o documento que comprova a quitação da dívida e que evita nova cobrança.

Se o vendedor emitir o recibo e não registrar o valor no fluxo de caixa, mesmo que com acordo com o comprador, este pode, de forma oportunista, registrá-lo como pagamento no seu fluxo. Isso pode ocorrer porque há aí uma assimetria de informação: o vendedor normalmente não tem acesso aos registros do comprador e não pode saber se efetivamente ele irá cumprir com o acordo ou não.

Se o comprador registrar de fato o pagamento em seu fluxo tributável, um simples exame de circularização da auditoria fiscal pode identificar a fraude com facilidade. 
O comprador só vai consentir com a não emissão de recibo quando puder abrir mão do benefício do mesmo, seja porque não pode deduzi-lo de seu imposto a pagar, seja porque a probabilidade de ser cobrado novamente pela mesma compra seja pequena.

Um outro problema que pode ocorrer em termos de evasão é a manipulação via transações virtuais de caixa, o que deve ser objeto de regulamentação para que seja evitado.

Desse modo, é possível que haja uma redução das práticas de elisão e evasão apenas com a mudança da forma de apuração do valor tributável para a base geração de caixa, embora o modelo proposto não seja capaz de cobrir todos os problemas inerentes à própria tributação da renda. 


\section{CONCLUSÃO}

Este trabalho procurou desenvolver e analisar os impactos de um modelo de tributação da renda por fluxos de caixa, tendo em vista três motivos:

- $\quad$ problemas na capacidade de pagamento do contribuinte, em função de o vencimento do IR ocorrer, em média, antes do recebimento das vendas;

- a interferência da legislação tributária na aplicação dos princípios contábeis, o que pode distorcer as informações e prejudicar os usuários da informação;

- a magnitude e a regressividade dos custos de conformidade por parte do contribuinte e a magnitude dos custos administrativos, pelo lado do fisco.

Em função desses motivos, o problema analisado foi o impacto da adoção de um modelo de tributação da renda com base em fluxos de caixa realizados sobre os pontos acima e sobre um adicional: a arrecadação.

Para isso, foram levantadas as bases teóricas para a elaboração do modelo proposto, que por sua vez contou com conceitos contábeis para o seu desenvolvimento.

Para a elaboração do modelo, foram levantados e desenvolvidos os conceitos de renda e de lucro e suas relações. Foi analisada a composição do lucro, sua mensuração e a avaliação de ativos e passivos, chegando ao conceito de caixa. Isso tudo foi analisado sob o ponto de vista da tributação: o que é atualmente o lucro tributável e o que deveria ser, e como deve ser a tributação com base nos fluxos de caixa. 
O modelo proposto é caracterizado pela apuração da base de cálculo a partir dos recebimentos e pagamentos operacionais e de investimentos. Entretanto, também foram analisados aspectos das movimentações virtuais de caixa, da inflação, dos fluxos de caixa não-tributáveis, da alíquota, das deduções do imposto a pagar e a composição do caixa e equivalentes caixa.

A partir do modelo elaborado, foram analisados os possíveis impactos do mesmo sobre as questões apontadas inicialmente: capacidade contributiva, interferência da legislação tributária, custos de conformidade e arrecadação.

Separamos aqui esses impactos e as características do modelo em pontos fortes e fracos.

Apontamos a seguir os principais pontos fortes do modelo proposto:

- Maior facilidade de apuração: em comparação com o modelo lucro, o modelo apresenta uma maior facilidade de apuração, porque não depende de se definir o momento de reconhecimento dos fluxos, uma vez que a base de cálculo do tributo é formada por pagamentos e recebimentos realizados. Isso implica em menores custos;

- Aumenta a capacidade contributiva: isso ocorre porque o contribuinte já tem geração de caixa suficiente para realizar o pagamento do tributo, o que não acontece com o modelo baseado em lucro, em que o vencimento pode estar antes do prazo médio de recebimento de vendas. Além disso, pode aumentar a capacidade econômica, pela possível redução na necessidade de financiamento para realizar o pagamento dos tributos ou por poder pagá-los no vencimento, sem atraso; 
- Reduz a interferência das normas tributárias sobre os princípios contábeis, uma vez que a normatização do modelo baseado em caixa deve ocorrer sobre os fluxos tributáveis e não-tributáveis e questões relacionadas à isso, e não mais sobre o reconhecimento e mensuração dos resultados contábeis;

- Pode reduzir os custos de conformidade do contribuinte, se for considerado todo o processo de pagar o tributo, que vai desde 0 conhecimento das normas tributárias até atividades relacionadas com ações judiciais;

- Empresas podem ser beneficiadas, com custos menores e a possibilidade de utilizar melhor a contabilidade, nos casos em que 0 principal usuário da informação contábil é o fisco, se a exigência da escrituração contábil não continuar;

- A apuração do fluxo de caixa pode acrescentar à vida de muitas empresas um instrumento importante, mas ainda pouco utilizado na tomada de decisão: a demonstração dos fluxos de caixa realizados;

- Pode reduzir os custos de conformidade do governo: do mesmo modo, o processo de arrecadação do tributo, que abrange atividades como a aprovação de normas tributárias e processos judiciais, pode ter seus custos reduzidos;

- Pode reduzir a elisão e a evasão fiscal, principalmente em função de os recebimentos e pagamentos serem menos manipuláveis e haver um incentivo menor para isso por parte do contribuinte; 
- O pagamento dos tributos pelo fluxo de caixa beneficia o contribuinte em função da própria volatilidade dos fluxos, conforme observado no teste empírico sobre a arrecadação;

- A arrecadação pode até ser equivalente à arrecadação obtida com o modelo baseado em lucro, mesmo quando for implantado, em função de as empresas estarem em marcha.

Entretanto, não existe modelo perfeito. Podemos indicar os seguintes pontos fracos deste:

- Problemas da tributação sobre a renda: o modelo continua com alguns problemas inerentes à própria tributação da renda:

○ todas as atividades informais são isentas;

- como o pagamento dos juros é dedutível, as atividades com baixas taxas de endividamento têm um peso tributário maior;

- continua havendo certo incentivo à sonegação, uma vez que a tributação depende da informação apurada pelo próprio contribuinte;

- Demanda regulamentação, o que envolve custos por parte do governo e abre brecha para que continue, embora em menor grau, havendo mudanças recorrentes na legislação;

- A dedutibilidade dos investimentos, apesar de tecnicamente correta e não significar postergação de imposto na implantação da sistemática em função de as empresas estarem em marcha, eventualmente realizando 
novos investimentos ou não, pode causar irracional estranheza e ser alvo de discussão política;

- A maior volatilidade dos fluxos de caixa, comparada com os lucros, pode trazer acréscimo de risco em termos de arrecadação do governo.

Apesar de ser uma questão subjetiva, em que há a necessidade de impor pesos, em termos de importância, a cada um desses pontos positivos e negativos, defendemos a opinião de que o modelo proposto de tributação da renda por fluxos de caixa apresenta pontos positivos que superam os negativos.

Analisando o trabalho em si, deve-se dizer que a sua contribuição não está na idéia de tributar a renda por fluxos de caixa, que não é nova, mas podemos identificar algumas outras contribuições:

- a elaboração do modelo com o uso de conceitos contábeis;

- a rediscussão dos conceitos de renda, lucro e fluxos de caixa tributáveis à luz da teoria contábil;

- a identificação dos motivos que indicam que a geração de caixa pode aumentar a capacidade contributiva;

- a identificação de motivos econômicos para a existência de custos de conformidade, como eles se processam e como podem ser reduzidos;

- a verificação empírica do possível comportamento da arrecadação obtenível com o modelo de tributação proposto;

- a indicação de como a tributação por fluxos de caixa pode reduzir a elisão e a evasão fiscal. 
O trabalho de pesquisa em contabilidade também envolve 0 desenvolvimento de novos modelos e alternativas que possam melhorar a vida dos indivíduos e das entidades econômicas. É isso que se procurou fazer neste trabalho, e sugere-se a elaboração de novas pesquisas que possam caminhar nesse sentido, utilizando conceitos e técnicas contábeis, atualmente tão amplas.

Acreditamos que o trabalho também possa de alguma maneira contribuir para a melhoria de um aspecto importante: a valorização do profissional contador, pois com a passagem da apuração do imposto de renda para a base fluxos de caixa, o contador pode começar a perder a imagem de mero 'apurador de imposto' e passar a ser visto como peça fundamental no processo de tomada de decisão de qualquer empresa ou entidade. 


\section{BIBLIOGRAFIA}

AARON, Henry. Inflation and the income tax. American Economic Association, vol. 66, n. 2, may 1976.

ALM, James. A perspective on the experimental analysis of taxpayer reporting. The Accounting Review, Vol. 66, n.3, Jul.1991, p. 577-593.

ALMEIDA, Neicyr de. Irpj e omissão de receitas: (uma visão crítica estudo de casos). São Paulo: Dialética, 2000.

AMARO, Luciano. Direito tributário brasileiro. 4.ed. São Paulo: Saraiva, 1999.

ARENAS, Pablo. Auditoría: aproximación al concepto de auditoria fiscal.

Disponível em <http://ciberconta.unizar.es/LECCION/auditoria01/100. HTM>. Acesso em 15/05/2003.

ASSAF Neto, Alexandre. Finanças corporativas e valor. São Paulo: Atlas, 2003.

ASSAF Neto, Alexandre, MARTINS, Eliseu. Administração financeira. São Paulo: Atlas, 1990.

BALEEIRO, Aliomar. Uma introdução à ciência das finanças. 14.ed. Rio de Janeiro: Forense, 1986. 
BARTH, Mary E. CRAM, Donald P. NELSON, Karen K. Accruals and the prediction of future cash flows. The Accounting Review, vol. 76, n.1, Jan. 2001, p. 27-58.

BERTOLUCCI, Aldo V. NASCIMENTO, Diogo T. Quanto custa pagar tributos? Revista Contabilidade \& Finanças-USP, São Paulo, n. 29, p.55-67, maio/ago. 2002.

BIRD, Francis A. Accounting theory: conceptual CPA approach. Richmond, Virginia: Robert F. Dame, 1979.

BRAGA, Márcio B. Algumas considerações teóricas e implicações decorrentes da relação contratual entre credor e devedor sob a hipótese de existência de assimetria de informação. Texto para Discussão - Séria Economia. FEA-RP/USP, 2000.

BRENNAN, M.J., SCHWARTZ, E.S. Corporate income taxes, valuation, and the problem of optimal capital structure. Journal of Business, vol. 51, n. 1, 1978.

BROWN, E. Cary, BULOW, Jeremy I. The definition of taxable business income. IN: PECHMAN, Joseph A. (editor). Comprehensive income taxation. Washington: The Brooking Institution, 1977.

BUZBY, Stephen L. The nature of adequate disclosure. IN: McCULLERS, Levis D., SCHROEDER, Richard G. Accounting theory: text and readings. 2.ed. New York, John Wiley \& Sons, 1982. 
CAMERON, James B., WOEFEL, Charles J., PATTILO, James W. Advanced accounting: theory and practice. Boston: Houghton Mifflin, 1979.

CAMPOS Filho, A. Fluxo de caixa em moeda forte: análise, decisão e controle. 2.ed. São Paulo: Atlas, 1993.

CHANG, Emily C. Business income in accounting and economics. The Accounting Review, p. 636-44.

CONTI, José M. Princípios tributários da capacidade contributiva e da progressividade. São Paulo: Dialética, 1996.

COPELAND, Tom, KOLLER, Tim, MURRIN, Jack. Valuation: measuring and managing the value of companies. 2.ed. New York: John Wiley \& Sons, 1996.

Conselho Federal de Contabilidade. Contribuição do Conselho Federal de Contabilidade ao processo de reforma tributária. Brasília: CFC, 1996.

DAMODARAN, Aswath. Finanças corporativas aplicadas. Porto Alegre: Bookman, 2002.

DAVIS, Jon S. SWENSON, Charles W. Experimental evidence on tax incentives and the demand for capital investments. The Accounting Review, vol. 68, n. 3, Jul.1993, p. 482-514. 
DECHOW, Patricia M., KOTHARI, S.P., WATTS, Ross L. The relation between earnings and cash flows. Journal of Accounting and Economics. No. 25,1998, p. $133-168$.

DEMPSEY, Mike. Capital gains tax: implications for the firm's cost of capital, share valuation and investment decision-making. Accounting and Business Research, vol. 28, n. 2, Spring Issue, p.91-96.

EATON, B.C., EATON, D.F. Microeconomia. São Paulo: Saraiva, 1999.

ECKSTEIN, Otto. Economia financeira: introdução à política fiscal. Rio de Janeiro: Zahar editores, 1971.

EDWARDS, Edgar O. BELL, Philip W. The theory and measurement of business income. Berkeley: University of California Press, 1961.

EHRBAR, Al. EVA: valor econômico agregado. Rio de Janeiro: Qualitymark, 1999.

Estrutura tributária federal - impostos e contribuições. Secretaria da Receita Federal. Disponível em <http://www.receita.fazenda.gov.br>. Acesso em 15 jul. 2002.

FISHER, Irving. The nature of capital and income. New York: Augustus M. Kelley, 1965.

FREZATTI, Fábio. Contribuição para o estudo da complementaridade do lucro e do fluxo de caixa na gestão de negócios no ambiente 
empresarial brasileiro. Tese (doutoramento). São Paulo: FEA/USP, 1996.

. Gestão do fluxo de caixa diário. São Paulo: Atlas, 1997.

GLAUTIER, M.W.E., UNDERDOWN, B. Accounting theory and practice. 5.ed. London: Pitman, 1994.

GONÇALVES, José A.L. Imposto sobre a renda: pressupostos constitucionais. São Paulo: Malheiros, 2002.

GRAETZ, Michael J. Expenditure tax design. IN: PEACHMAN, Joseph A. (editor). What should be taxed: income or expenditure? Washington: The Brookings institution, 1980.

GUERREIRO, Reinaldo. Mensuração do resultado econômico. Caderno de Estudos FIPECAFI FEA/USP.

HALLER, Axel. The relationship of financial and tax accounting in Germany. IN: BLAKE, John, HOSSAIN, Mahmud. Readings in international accounting. London: International Thomson Business Press, 1996.

HARADA, Kiyoshi (coord.). Temas de direito tributário. São Paulo: Editora Juarez de Oliveira, 2000.

HARBERGER, Arnold C. Taxation and welfare. Boston: Little, Brown and company, 1974. 
HENDRIKSEN, Eldon S. VAN BREDA, Michael F. Teoria da contabilidade. São Paulo: Atlas, 1999.

HICKS, J. R. Value and Capital. London: Oxford University Press, 1946.

HIGUCHI, Hiromi, HIGUCHI, Celso H. Imposto de renda das empresas: intepretação e prática. 26.ed. São Paulo: Atlas, 2001.

ICHIHARA, Yoshiaki. Direito tributário. 9.ed. São Paulo: Atlas, 2000.

IUDÍCIBUS, Sérgio de. Teoria da contabilidade. 5.ed. São Paulo: Atlas, 1997.

IUDÍCIBUS, Sérgio de, MARTINS, Eliseu, GELBCKE, Ernesto R. Manual de contabilidade das sociedades por ações (aplicável às demais sociedades). 5.ed. São Paulo: Atlas, 2000.

JAEDICKE, Robert K., SPROUSE, Robert T. Fluxos contábeis: rendas, fundos e capital. São Paulo: Atlas, 1972.

JALBERT, Terrance. Pass-through taxation and the value of the firm. American Business Review, vol.20, Issue 2, p. 47-54.

KAM, Vernon. Accounting theory. New York: John Wiley \& Sons, 1985.

KEYNES, John M. A teoria geral do emprego, do juro e da moeda. São Paulo: Atlas, 1982. 
KING, Mervyn A. The cash flow corporate income tax. IN: FELDSTEIN, Martin. The effects of taxation on capital accumulation. Chicago: The University of Chicago Press, 1987.

LEMKE, Gisele. Imposto de Renda: os conceitos de renda e de disponibilidade econômica e jurídica. São Paulo: Dialética, 1998.

LITTLETON, A.C., ZIMMERMAN, V.K. Accounting theory: continuity and change. Englewood Cliffs: Prentice-hall, 1962.

LUSTOSA, Paulo R.B. Um estudo das relações entre o lucro contábil, os fluxos realizados de caixa das operações e o valor econômico da empresa: uma simulação aplicada a um banco comercial. Tese (doutoramento). São Paulo: FEA/USP, 2001.

MACHADO, Hugo de Brito. Curso de direito tributário. 21.ed. São Paulo: Malheiros, 2002.

MARTINS, Ives G. S. (coord.). Direitos fundamentais do contribuinte. São Paulo: Editora Revista dos Tribunais : Centro de Extensão Universitária, 2000.

MARTINS, Eliseu (org.). Avaliação de empresas: da mensuração contábil à econômica. São Paulo: Atlas, 2001.

MARTINS, Eliseu. Contabilidade vs. fluxo de caixa. Caderno de Estudos FIPECAFI, São Paulo, n. 2, p.1-12, abril 1991. 
MARTINS, Eliseu. Contribuição à avaliação do ativo intangível. Tese (doutoramento). São Paulo: Universidade de São Paulo, 1972.

MARTONE, Celso L. et al. Uma proposta de reforma fiscal para o Brasil. São Paulo: FIPE, 1994.

MATTOS Filho, Ary Oswaldo. Reforma fiscal: coletânea de estudos técnicos. Vol. II. São Paulo: DBA, ?.

McDONALD, Daniel L. Corporative accounting theory. Massachusetts: Addison-Wesley, 1972.

MILGROM, P.R., ROBERTS, J. Economics, organization and management. Englewood Cliffs, New Jersey: Prentice Hall, 1992.

MILLER, Merton. The Modigliani Miller propositions after thirty years. IN: The revolution in corporate finance. 3.ed.

MITCHELL, Bert N. A comparison of accounting and economic concepts of business income. IN: McCULLERS, Levis D. SCHROEDER, Richard G. Accounting theory: text and readings. 2. ed. New York: John Wiley \& Sons, 1982.

MOST, Kenneth S. Accounting theory. 2.ed. Columbus: Grid, 1982.

OLIVEIRA, Regis F. HORVATH, Estevão. Manual de direito financeiro. 5.ed. São Paulo: Editora Revista dos Tribunais, 2002. 
OLIVEIRA, Ricardo M. Princípios fundamentais do imposto de renda. IN: SCHOUERI, Luís E., ZILVETI, Fernando A. Direito tributário: estudos em homenagem a Brandão Machado. São Paulo: Dialética, 1998.

PINDYCK, Robert S., RUBINFELD, Daniel L. Microeconomia. São Paulo: Prentice Hall, 2002.

PINHEIRO, Armando C., MOURA, Alkimar. Segmentação e uso de informação nos mercados de crédito brasileiros. Textos para Discussão n. 88. Rio de Janeiro: BNDES, 2001.

RAPPAPORT, Alfred. Gerando valor para o acionista. São Paulo: Atlas, 2001.

REZENDE, Fernando A. Finanças públicas. 2.ed. São Paulo: Atlas, 2001.

ROCHA, Valdir O. (coord.). Imposto de renda: questões atuais e emergentes. São Paulo: Dialética, 1995.

(coord.).Grandes questões atuais do direito tributário. 2. Vol. São Paulo: Dialética, 1998.

(coord.). Imposto de renda: alterações fundamentais. São Paulo: Dialética, 1996.

ROSS, Stephen A., WESTERFIELD, Randolph W. JAFFE, Jeffrey $F$. Administração financeira. São Paulo: Atlas, 1995.

SCHOUERI, Luís E., ZILVETI, Fernando A. Direito tributário: estudos em homenagem a Brandão Machado. São Paulo: Dialética, 1998. 
SACHS, Jeffrey D. LARRAIN B, Felipe. Macroeconomia. Ed. rev. atual. São Paulo: Makron Books, 2000.

SANTI Filho, Armando de., OLINQUEVITCH, José L. Análise de balanços para controle gerencial. 3.ed. São Paulo: Atlas, 1995.

SILVA, Alexandre dos S. Análise das formas de reconhecimento da receita na contabilidade: um enfoque no conceito econômico de lucro. Dissertação (mestrado). São Paulo: FEA/USP, 2000.

SILVA, Fernando A.R. 0 imposto sobre a renda e a justiça fiscal. Rio de Janeiro: IPEA/INPES, 1974.

SILVA, José Saldanha G. Tributação sobre a renda e capitalismo. São Paulo: Atlas, 1946.

SILVA, Laercio B. A contabilidade no Brasil: aspectos do desenvolvimento por influência da legislação e do contabilista. Dissertação (mestrado). São Paulo: FEA/USP, 1980.

SUMMERS, Lawrence $\mathrm{H}$. Investment incentives and the discounting of depreciation allowances. IN: FELDSTEIN, Martin. The effects of taxation on capital accumulation. Chicago: The University of Chicago Press, 1987. 